\title{
9. LATE CRETACEOUS TO PLEISTOCENE CALCAREOUS NANNOFOSSILS FROM THE SOUTH ATLANTIC, DEEP SEA DRILLING PROJECT LEG 731
}

\author{
Stephen F. Percival, Jr., Mobil Exploration and Producing Services, Inc., Dallas, Texas
}

\begin{abstract}
Six sites were drilled in the South Atlantic on DSDP Leg 73. The sediment recovered ranges in age from Late Cretaceous to Pleistocene. Five sites (519-523) were drilled on the Mid-Atlantic Ridge on Tertiary magnetic anomalies. One site (524) was drilled on the Walvis Ridge on Upper Cretaceous crust. Paleontologic dates agree well with magnetostratigraphic dates at the sites drilled on the Mid-Atlantic Ridge. As on Leg 3, a Braarudosphaera chalk is found at Sites 522 and 523 in the Oligocene. At the Walvis Ridge site, Site 524, a continuous section across the Cretaceous/Tertiary boundary was cored. Evidence suggests that the Cretaceous forms found mixed with Danian forms immediately above the boundary are in situ and not reworked.
\end{abstract}

\section{INTRODUCTION}

In total, 1000 samples were recovered from six sites that were drilled in the South Atlantic on DSDP Leg 73. The samples were examined for calcareous nannofossils for the purpose of making biostratigraphic age determinations. All samples were studied by light microscopy. The sediments ranged in age from Late Cretaceous to Pleistocene, and almost all contained a very abundant, moderately well preserved nannoflora. Tables 1 to 12 contain the species distribution for each sample and the nannofossil zonation recognized at each site. In the preservation code used in the tables, $\mathrm{P}=$ poor, $F=$ fair, and $G=$ good. All frequencies are estimated. The total flora frequencies are as follows: VR (very rare) $=1-4, R$ (rare) $=5-10, F$ (frequent) $=11-30, C$ (common) $=31-50, A$ (abundant) $=51-100$, and VA (very abundant) $=>100$. The individual species frequencies are as follows: VR (very rare) $=1-2, R$ (rare) $=3-5, \mathrm{~F}$ (frequent) $=6-10, \mathrm{C}($ common $)=11-25, \mathrm{~A}$ (abundant) $=26-50$, and VA (very abundant $)=>50$.

In the discussion below, the information that resulted from the examination of the samples is presented from two different perspectives. First it is organized by calcareous nannofossil zone, with the oldest zones discussed first. Then it is organized by hole and sediment age, with the oldest sediments discussed last.

\section{CALCAREOUS NANNOFOSSIL ZONES}

\section{Cretaceous}

The Cretaceous nannofossil zones used are those presented by Perch-Nielsen (1977).

\section{Nondiagnostic Zone}

Definition. Interval from the first occurrence of Micula staurophora to the first occurrence of Nephrolithus frequens.

\footnotetext{
${ }^{1}$ Hsï, K. J., LaBrecque, J. L., et al., Init. Repts. DSDP, 73: Washington (U.S. Govt. Printing Office).
}

Stratigraphic position. Upper Turonian to Maestrichtian.

Remarks. This zone is found at Hole 524. The low species diversity, poor to fair preservation, and absence of marker species account for the indefinite age determination.

\section{Nephrolithus frequens Zone}

Author of marker species. Čepek and Hay, 1969, emend. Perch-Nielsen, 1977.

Definition. Interval from the first occurrence of Nephrolithus frequens to the first occurrence of Micula mura.

Stratigraphic position. Upper Maestrichtian.

Remarks. This zone occurs as a thin interval in the sediments at Hole 524 .

\section{Micula mura Zone}

Author of marker species. Martini, 1969, emend. this paper.

Definition. Interval from the first occurrence of Micula mura to the first occurrence of Zygodiscus sigmoides.

Remarks. The Micula mura Zone is found at Hole 524. At this site Nephrolithus frequens occurs throughout the range of $M$. mura. The use of the first occurrence of Zygodiscus sigmoides is necessitated by the occurrence of an abundance of typical Maestrichtian forms with an abundance of typical Danian forms for a considerable distance above the iridium concentration horizon (Hsü et al., 1982) at Hole 524. It was difficult to decide whether the Maestrichtian forms were reworked or in situ. Oxygen-isotope work by Hsü et al. (1982) suggests that the Maestrichtian forms are indeed in situ.

\section{Tertiary and Quaternary}

The zonation proposed by Martini (1971) is used for the six sites drilled on Leg 73 . Zonations developed by Bukry $(1973,1975)$ and Okada and Bukry $(1980)$ are used in addition to Martini's for the Paleogene sediments of 
Holes 522 and 523. The author uses the species ranges of Martini (1971) and Bukry (1973).

At times the marker species used by Martini (1971) to define a particular zone are absent. Under these circumstances the author used secondary species to mark a zone, although the range of a secondary species may not be exactly the same as that of the primary species. Zones defined by secondary species are indicated by an asterisk. In the tables one may also find (for example) Zone NN11, followed by NN10/11, finally followed by NN10. In Zone NN10/11 in this sequence, the NN11 marker species is absent but a secondary species is present. Further, neither the marker species for Zone NN10 nor a secondary species is present; therefore, one cannot locate the top of NN10 strictly.

\section{Markalius astroporus Zone, NP1*}

Definition. Interval from the last occurrence of Cretaceous species to the first occurrence of Cruciplacolithus edwardsii.

Remarks. Herein, this zone is defined as the first occurrence of Zygodiscus sigmoides to the first occurrence of Cruciplacolithus edwardsii and Coccolithus pelagicus at Hole 524. The first occurrence of $Z$. sigmoides is used because of the abundance of Late Cretaceous species with an abundance of typical Danian forms, such as Markalius astroporus, Thoracosphaera operculata, Neochiastozygus concinnus, and Biantholithus sparsus. Thierstein and Okada (1979) attributed a similar occurrence to benthic mixing. Cruciplacolithus edwardsii is in part a junior synonym of $C$. tenuis (Romein, 1979).

\section{Cruciplacolithus edwardsii Zone, NP2}

Definition. Interval from the first occurrence of Cruciplacolithus edwardsii to the first occurrence of Chiasmolithus danicus.

Remarks. As at Hole 524, this zone is identified as the interval from the first occurrence of Cruciplacolithus edwardsii and Coccolithus pelagicus to the first occurrence of Chiasmolithus danicus.

\section{Chiasmolithus danicus Zone, NP3}

Definition. Interval from the first occurrence of Chiasmolithus danicus to the first occurrence of Ellipsolithus macellus.

Remarks. The above definition is followed in the identification of the zone at Hole 524.

\section{Ellipsolithus macellus Zone, NP4}

Definition. Interval from the first occurrence of $E l$ lipsolithus macellus to the first occurrence of Fasciculithus tympaniformis.

Remarks. The primary guide species are used to recognize this zone at Hole 524.

\section{Fasciculithus tympaniformis Zone, NP5}

Definition. Interval from the first occurrence of Fasciculithus tympaniformis to the first occurrence of $\mathrm{He}$ liolithus kleinpellii.

Remarks. At Hole 524 the above zonal definition is followed.

\section{Heliolithus kleinpellii Zone, NP6}

Definition. Interval from the first occurrence of $\mathrm{He}$ liolithus kleinpellii to the first occurrence of Discoaster mohleri.

Remarks. Both of the above species occur in their anticipated order at Hole 524.

\section{Discoaster mohleri Zone, NP7*}

Definition. Interval from the first occurrence of Discoaster mohleri to the first occurrence of Heliolithus riedeli.

Remarks. Since Heliolithus riedeli is absent at Hole 524, the extinction datum of Heliolithus kleinpellii is used to approximate the upper boundary. The lower boundary is placed at the first occurrence of Discoaster mohleri.

\section{Heliolithus riedeli Zone, NP8*}

Definition. Interval from the first occurrence of $\mathrm{He}$ liolithus riedeli to the first occurrence of Discoaster multiradiatus.

Remarks. As stated previously, Heliolithus riedeli is absent at Hole 524; therefore, the horizon at the extinction datum of Heliolithus kleinpellii is chosen to be the lower boundary. The upper boundary is delineated by the first appearance of Discoaster multiradiatus.

\section{Discoaster multiradiatus Zone, NP9*}

Definition. Interval from the first occurrence of Discoaster multiradiatus to the first occurrence of Tribrachiatus bramlettei.

Remarks. Tribrachiatus bramlettei is absent at Hole 524 and Hole 524A; thus, the last occurrence of the secondary species Discoaster mohleri is used to define the upper boundary. The lower boundary remains the same.

\section{Tribrachiatus contortus Zone, NP10*}

Definition. Interval from the first occurrence of Tribrachiatus bramlettei to the last occurrence of $T$. contortus.

Remarks. Since both primary species are absent at Holes 524, 524A, and 524B, the extinction datum of the secondary species Discoaster mohleri is used as the base and the last occurrence of $D$. multiradiatus as the top. The top was not encountered at Holes 524A and 524B.

\section{Discoaster binodosus Zone, NP11*}

Definition. Interval from the last occurrence of Tribrachiatus contortus to the first occurrence of Discoaster lodoensis.

Remarks. At Hole 524, Tribrachiatus contortus is missing, and the last occurrence of Discoaster multiradiatus is used as the base. For the top, the first occurrence of $D$. lodoensis is used. At Hole 524B NP11 is missing.

\section{Tribrachiatus orthostylus Zone, NP12}

Definition. Interval from the first occurrence of Discoaster lodoensis to the last occurrence of Tribrachiatus orthostylus. 
Remarks. According to the above definition this zone was recognized at Holes 524 and 524B. The top is not reached at Hole 524.

\section{Discoaster lodoensis Zone, NP13}

Definition. Interval from the last occurrence of Tribrachiatus orthostylus to the first occurrence of Discoaster sublodoensis.

Remarks. As defined above, the base of this zone is found at Hole 524B; however, the top is not reached.

\section{Discoaster sublodoensis Zone, NP14}

Definition. Interval from the first occurrence of Discoaster sublodoensis to the first occurrence of Nannotetrina fulgens. sites.

Remarks. This zone is not recognized at any of the

\section{Nannotetrina fulgens Zone, NP15*}

Definition. Interval from the first occurrence of Nannotetrina fulgens to the last occurrence of Rhabdolithus gladius.

Remarks. At Hole 523, the base of this zone was not reached, and the last occurrence of Chiasmolithus gigas is used to approximate the top, since Rhabdolithus gladius is absent. This interval at Hole 523 equals the CP13b C. gigas Subzone of the CP13 Nannotetrina fulgens Zone of Okada and Bukry (1980).

\section{Nannotetrina fulgens, NP15/Discoaster tani nodifer Zone, NP16}

Remarks. This interval at Hole 523 is characterized by the presence of Nannotetrina fulgens without Rhabdolithus gladius and Chiasmolithus gigas. It correlates with the CP13c Coccolithus staurion Subzone of the CP13 N. fulgens Zone of Okada and Bukry (1980).

\section{Discoaster tani nodifer Zone, NP16*}

Definition. Interval from the last occurrence of Rhabdolithus gladius to the last occurrence of Chiasmolithus solitus.

Remarks. At Hole 523 the lower boundary is recognized by the last occurrence of Nannotetrina fulgens. The upper boundary is picked on the primary species mentioned above. This interval equals the upper part of the CP13c Coccolithus staurion Subzone of the CP13 $N$. fulgens Zone and the CP14a Discoaster bifax Subzone of the CP14 Reticulofenestra umbilica Zone of Okada and Bukry (1980).

\section{Discoaster saipanensis Zone, NP17*}

Definition. Interval from the last occurrence of Chiasmolithus solitus to the first occurrence of $C$. oamaruensis.

Remarks. The base of the zone at Hole 523 agrees with the definition of the zone. However, because of the rarity of Chiasmolithus oamaruensis the top is picked on the extinction of $C$. grandis. The interval correlates with the CP14b Discoaster saipanensis Subzone of the CP14 Reticulofenestra umbilica Zone of Okada and Bukry (1980).

\section{Chiasmolithus oamaruensis Zone, NP18*}

Definition. Interval from the first occurrence of Chiasmolithus oamaruensis to the first occurrence of Isthmolithus recurvus.

Remarks. As mentioned previously, the extinction of Chiasmolithus grandis is used for the base at Hole 523. The top is placed at the first occurrence of Isthmolithus recurvus. This interval equals much of the CP15a $C$. oamaruensis Subzone of the CP15 Discoaster barbadiensis Zone of Okada and Bukry (1980).

\section{Isthmolithus recurvus Zone, NP19}

Definition. Interval from the first occurrence of Isthmolithus recurvus to the first occurrence of Sphenolithus pseudoradians.

Remarks. This primary marker is present at Hole 523. This interval is extremely short and correlates with a small part of the CP15a Chiasmolithus oamaruensis Subzone of the CP15 Discoaster barbadiensis Zone of Okada and Bukry (1980).

\section{Sphenolithus pseudoradians Zone, NP20}

Definition. Interval from the first occurrence of Sphenolithus pseudoradians to the last occurrence of Discoaster saipanensis.

Remarks. The above definition is used to recognize this zone at Hole 523. At Holes 522, 522A, and 522B the base was not reached. This interval equals a small upper part of the CP15a Chiasmolithus oamaruensis Subzone and all of the CP15b Isthmolithus recurvus Subzones of the CP15 Discoaster barbadiensis Zone of Okada and Bukry (1980).

\section{Ericsonia subdisticha Zone, NP21}

Definition. Interval from the last occurrence of Discoaster saipanensis to the last occurrence of Coccolithus formosus.

Remarks. The above definition is used to identify this zone at Holes 522, 522A, and 523. This zone correlates with the CP16a Ericsonia subdisticha Subzone and the $\mathrm{CP} 16 \mathrm{~b}$ Coccolithus formosus Subzone of the CP16 Helicosphaera reticulata Zone of Okada and Bukry (1980).

\section{Helicosphaera reticulata Zone, NP22}

Definition. Interval from the last occurrence of Coccolithus formosus to the last occurrence of Reticulofenestra umbilica.

Remarks. At Holes 522, 522A, 522B, and 523 the above definition is used. The top and base are not reached at Hole 522B. This interval equals the CP16c Reticulofenestra hillae Subzone of the CP16 Helicosphaera reticulata Zone of Okada and Bukry (1980).

\section{Sphenolithus predistentus Zone, NP23*}

Definition. Interval from the last occurrence of $R e$ ticulofenestra umbilica to the first occurrence of Sphenolithus ciperoensis.

Remarks. The above definition is used at Holes $\mathbf{5 2 2}$ and 522A. However, Sphenolithus ciperoensis is extremely rare at Hole 523; therefore, the extinction of $S$. 
pseudoradians is used. The latter species has its last occurrence well within NP23. This interval correlates with the CP17 S. predistentus Zone and CP18 S. distentus Zone of Okada and Bukry (1980).

\section{Sphenolithus distentus Zone, NP24*}

Definition. Interval from the first occurrence of Sphenolithus ciperoensis to the last occurrence of $S$. distentus.

Remarks. At Holes 522 and 522A the above definition is followed. At Hole 523, as mentioned previously, the last occurrence of Sphenolithus pseudoradians is used as the base. This zone correlates with the CP19a Cyclicargolithus floridanus Subzone of the CP19 S. ciperoensis Zone of Okada and Bukry (1980).

\section{Sphenolithus ciperoensis Zone, NP25*}

Definition. Interval from the last occurrence of Sphenolithus distentus to the last occurrence of Helicosphaera recta.

Remarks. The above definition is used to determine the base at Holes 522, 522A, and 523. However, the extinction of Dictyococcites bisectus is used to determine the top. This zone equals the CP19b D. bisectus Subzone of the CP19 Sphenolithus ciperoensis Zone of Okada and Bukry (1980).

\section{Triquetrorhabdulus carinatus Zone, NN1*}

Definition. Interval from the last occurrence of Helicosphaera recta to the first occurrence of Discoaster druggi.

Remarks. Again the secondary species Dictyococcites bisectus is used for the base of this zone at Holes 522, 522A and 523. The last occurrence of Coccolithus eopelagicus is used for the top at Holes 522A and 523. The first occurrence of Discoaster druggi is used for Hole 522.

\section{Discoaster druggi, NN2/Sphenolithus belemnos Zone, NN3*}

Remarks. This interval is characterized by the total range of Discoaster druggi at Hole 522. This species is the marker for the base of NN2. The extinction of Sphenolithus belemnos is the marker species for the top of NN3; however, it is absent at Hole 522.

\section{Sphenolithus belemnos, NN3/Sphenolithus heteromorphus Zone, NN5*}

Remarks. For this interval the total range of Sphenolithus heteromorphus is used at Hole 522. The base of NN3 was defined by Martini (1971) as the last occurrence of Triquetrorhabdulus carinatus and the top of NN5 as the last occurrence of S. heteromorphus.

\section{Helicosphaera ampliaperta Zone, NN4*}

Definition. Interval from the last occurrence of Sphenolithus belemnos to the last occurrence of Helicosphaera ampliaperta.

Remarks. The top is identified at Holes 521 and 521A by using the last occurrence of Helicosphera euphratis, which has the same top as $H$. ampliaperta. The base was not reached.

\section{Helicosphaera ampliaperta, NN4/Discoaster exilis Zone, NN6*}

Remarks. This interval is identified by the author at Hole 523 as the interval from the first occurrence of Discoaster braarudii to the last occurrence of $D$. deflandrei. The base of NN4 is usually identified as the last occurrence of Sphenolithus belemnos.

\section{Sphenolithus heteromorphus Zone, NN5*}

Definition. Interval from the last occurrence of $\mathrm{Heli}$ cosphaera ampliaperta to the last occurrence of Sphenolithus heteromorphus.

Remarks. The base was not reached at Hole 520. At Holes 521 and 521A the base is characterized by the last occurrence of Helicosphaera euphratis.

\section{Discoaster exilis Zone, NN6*}

Definition. Interval from the last occurrence of Sphenolithus heteromorphus to the first occurrence of Discoaster kugleri.

Remarks. At Holes 520 and 521, this zone is identified by the extinction of Sphenolithus heteromorphus at the base and the extinction of the secondary species Discoaster deflandrei at the top.

\section{Discoaster kugleri Zone, NN7*}

Definition. Interval from the first occurrence of Discoaster kugleri to the first occurrence of Catinaster coalitus.

Remarks. This zone is identified herein as the total range of Discoaster kugleri at Hole 520 because there is no overlap of $D$. kugleri and Catinaster coalitus.

\section{Discoaster kugleri, NN7/Catinaster coalitus Zone, NN8*}

Remarks. This interval lies between the last occurrence of Discoaster kugleri and the first occurrence of Catinaster coalitus at Hole 520. This interval would normally be characterized by the first occurrence of $D$. kugleri at its base and the first occurrence of $D$. hamatus at its top.

\section{Catinaster coalitus, NN8/Discoaster calcaris Zone, NN10*}

Remarks. The base of this interval is defined by the first occurrence of Catinaster coalitus; the top, by the first occurrence of Discoaster quinqueramus. This is the definition used at Hole 520.

\section{Discoaster hamatus, NN9/Discoaster calcaris Zone, NN10*}

Remarks. At Hole 521A this interval is recognized as the total range of Discoaster prepentaradiatus, inasmuch as both $D$. hamatus and $D$. quinqueramus, the first occurrences of which indicate the base and top respectively, are absent.

\section{Discoaster calcaris Zone, NN10*}

Definition. Interval from the last occurrence of Discoaster hamatus to the first occurrence of $D$. quinqueramus. 
Remarks. At Hole 520 the last occurrence of Catinaster calyculus is used as a top NN10 marker species, and the first occurrence of Discoaster quinqueramus is used as a base marker species for NN11. Since $D$. quinqueramus is absent at Hole 521A, the extinction of D. prepentaradiatus is used to define the top of NN10. Similarly, at Hole $519 \mathrm{D}$. quinqueramus is not present, and the last occurrence of $D$. prepentaradiatus and $C$. calyculus is used to indicate NN10. There is an apparent discrepancy in the lower range of $C$. calyculus that is resolved by considering the lower range at Hole 519 to be latitudinally controlled.

\section{Discoaster calcaris, NN10/Discoaster quinqueramus Zone, NN11*}

Remarks. At Hole 519 Discoaster hamatus and $D$. quinqueramus are absent, so this interval is defined as being from the last occurrence of Catinaster calyculus to the first occurrence of Amaurolithus primus.

\section{Discoaster quinqueramus Zone, NN11*}

Definition. Interval from the first to the last occurrence of Discoaster quinqueramus.

Remarks. Three different definitions of this zone are used. The primary definition (cited above) is used at Holes 520, 521, and 522. At Hole 519 the definition used is the interval from the first occurrence of Amaurolithus primus to the first occurrence of $A$. amplificus. At Holes 521 and 523 the definition used is the interval from the first occurrence of Discoaster surculus to the first occurrence of $A$. delicatus.

\section{Discoaster quinqueramus, NN11/Amaurolithus tricorniculatus Zone, NN12*}

Remarks. At Holes 519 and 519A, the author defines this interval as that between the first and last occurrence of Amaurolithus amplificus. At Hole 522 the interval is defined as being from the first occurrence of Amaurolithus primus and $A$. delicatus to the first occurrence of Ceratolithus rugosus. At Hole 523 this zone is defined as the interval from the first occurrence of $A$. delicatus to the first occurrence of $C$. rugosus. Both of these horizons are well within the boundaries of the zones they delimit.

\section{Amaurolithus tricorniculatus Zone, NN12}

Definition. Interval from the last occurrence of Discoaster quinqueramus to the first occurrence of Ceratolithus rugosus.

Remarks. The definition above is used at Holes $\mathbf{5 2 0}$ and 521. At Hole 519 the lower boundary is placed on the last occurrence of Amaurolithus amplificus.

\section{Ceratolithus rugosus Zone, NN13}

Definition. Interval from the first occurrence of $\mathrm{Ce}$ ratolithus rugosus to the first occurrence of Discoaster asymmetricus.

Remarks. The type definition is used to recognize this zone at Holes 519, 519A, 521, and 522.

\section{Discoaster asymmetricus Zone, NN14}

Definition. Interval from the first occurrence of Discoaster asymmetricus to the last occurrence of Amaurolithus tricorniculatus.

Remarks. The above definition is used to identify this zone at Holes 519, 519A, 520, 522, and 523.

\section{Discoaster asymmetricus, NN14/Reticulofenestra pseudoumbilica Zone, NN15*}

Remarks. The last occurrence of Amaurolithus tricorniculatus defines the boundary between NN14 and NN15. Since this species is rare at Hole 521, the NN14/ 15 boundary is difficult to define.

\section{Reticulofenestra pseudoumbilica Zone, NN15}

Definition. Interval from the last occurrence of Amaurolithus tricorniculatus to the last occurrence of Reticulofenestra pseudoumbilica.

Remarks. The type definition is used at Holes 519, 519A, 520, 522, and 523.

\section{Pseudoemiliania lacunosa Zone, NN19}

Definition. Interval from the last occurrence of Discoaster brouweri to the last occurrence of Pseudoemiliania lacunosa.

Remarks. The above definition is used to recognize this zone at Holes 519, 520, 521, 522, and 523.

\section{Gephyrocapsa oceanica Zone, NN20}

Definition. Interval from the last occurrence of Pseudoemiliania lacunosa to the first occurrence of Emiliania huxleyi.

Remarks. The type definition is used to identify this zone at Hole 512, 520, 521, 522, and 523.

\section{Emiliania huxleyi Zone, NN21}

Definition. Interval above the first occurrence of Emiliania huxleyi.

Remarks. The above definition is used to identify this zone at Hole 519. Since this zone is normally thin in open-ocean sediments, it can often be missed during sampling.

\section{SITE SUMMARIES}

Six sites were drilled on DSDP Leg 73. More than one hole was drilled at some sites. Five of the sites drilled were on the Mid-Atlantic Ridge and one site drilled was on the Walvis Ridge. Each hole is discussed separately below.

\section{Hole 519}

Hole 519 was drilled on the Mid-Atlantic Ridge at $26^{\circ} 08.20^{\prime} \mathrm{S}, 11^{\circ} 39.97^{\prime} \mathrm{W}$ in $3769 \mathrm{~m}$ of water. Thirty-six hydraulic piston cores were taken in $151.5 \mathrm{~m}$ of sediment, and one was taken in basement. All sediment cores contain a moderately well to well preserved, very abundant calcareous nannoflora. Sediments range in age from Pleistocene to late Miocene. The hole is located on a negative magnetic anomaly between Anoma- 
lies 5 and 5A. The assumed age is $9.8 \mathrm{~m} . \mathrm{y}$. The oldest calcareous nannofossil zone recovered is the NN10 Discoaster calcaris Zone*, if the first occurrences of the Catinaster spp. in this hole are not synchronous with their first occurrences in the Pacific. Such an interpretation would render the biostratigraphy in general agreement with the previously established magnetostratigraphy. An alternative interpretation assuming synchroneity of the first occurrences of the Catinaster spp. is discussed in the synthesis chapter (Hsü, Percival, et al., this vol.). Extensive slumping occurred at this site, so that the first 20 cores are stratigraphically mixed. The calcareous nannoflora of Pleistocene, Pliocene, and late Miocene age is mixed. Table 1 shows the stratigraphic distribution of calcareous nannofossils at Hole 519.

\section{Pleistocene}

The upper part of Section 519-1-1 contains an abundance of Emiliania huxleyi, which restricts it to the NN21 E. huxleyi Zone. The interval from the lower part of Section 519-1-1 to Section 519-2-3 represents the NN20 Gephyrocapsa oceanica Zone. This zone is recognized by the absence of both $E$. huxleyi and Pseudoemiliania lacunosa. The interval from Sample 519-2,CC to Section 519-11-1 contains $P$. lacunosa, which is the marker species for the NN19 P. lacunosa Zone. This interval also contains slumped sediments that can be assigned to Zones NN16, NN13, and NN11/12.

\section{Pliocene}

The interval from Section 519-11-2 to 519-12-2 is interpreted to be the NN18 Discoaster brouweri Zone. $D$. brouweri and $D$. triradiatus are abundant in this interval. A thin NN17 D. pentaradiatus Zone is found at Section 519-12-3, as indicated by the presence of the nominate species. From Sample 519-12,CC to Section $519-18-2$, the NN16 $D$. surculus Zone is encountered. $D$. surculus, $D$. pentaradiatus, and $D$. brouweri are very abundant throughout this interval. In the middle of this interval the extinction datum of $D$. asymmetricus and $D$. tamalis occurs. Again, there is mixing of upper Miocene (NN11/12) sediments. The top of the early Pliocene NN15 Reticulofenestra pseudoumbilica Zone is found at Section 519-18-3, on the basis of the last occurrence of $R$. pseudoumbilica. This zone covers the interval from Section 519-18-3 to 519-21-2. D. tamalis has its first appearance within Section 519-19-2. The NN14 $D$. asymmetricus Zone is defined as the interval from the first occurrence of $D$. asymmetricus to the last occurrence of Amaurolithus tricorniculatus. These events indicate the zone that covers the interval from Section 519-21-3 to Sample 519-23,CC. From Section 519-24-1 to Sample 519-26,CC Ceratolithus rugosus is found without $D$. asymmetricus, which indicates the NN13 $C$. rugosus Zone. The absence of $C$. rugosus and $A$. amplificus from Section 519-27-1 to 519-28-1 suggests that the upper part of the NN12 A. tricorniculatus Zone, which is basal Pliocene, is present.

\section{Miocene}

The Miocene/Pliocene boundary is placed at the extinction datum of Amaurolithus amplificus. The inter- val from Section 519-28-2 to 519-29-2 is assigned to the NN11 Discoaster quinqueramus/NN12 A. tricorniculatus Zone* on the basis of the total range of $A$. amplificus. $D$. quinqueramus, the NN11 marker species, is very rare within Section 519-29-2. The first occurrence of $A$. primus and $A$. delicatus, as seen in Sample 519-29,CC, occurs in the middle of NN11. The interval from Section 519-30-1 to 519-33-1 belongs to the NN10 D. calcaris/ NN11 D. quinqueramus Zone* undifferentiated. This assignment is suggested by the absence of Catinaster cal$y$ culus and $D$. prepentaradiatus. The concurrence of the latter two species marks the top of the NN10 Zone* at Section 519-33-2. The interval from Section 519-33-2 to Sample 519-36,CC belongs to the NN10 D. calcaris Zone* since $D$. hamatus, the NN9 $D$. hamatus Zone marker species, was not found. The first occurrence of C. calyculus may be latitudinally controlled here; it normally first appears within the NN8 $C$. coalitus Zone of middle Miocene age.

\section{Hole 519A}

Hole 519A was drilled on the Mid-Atlantic Ridge at $26^{\circ} 08.20^{\prime} \mathrm{S}, 11^{\circ} 39.97^{\prime} \mathrm{W}$ in $3769 \mathrm{~m}$ of water. Four rotary cores were taken intermittently in $150.5 \mathrm{~m}$ of sediments, and two were taken in basalt. Calcareous nannofossils are very abundant and moderately well to well preserved. Sediments range in age from Pliocene to late Miocene. Extensive slumping occurred at the hole; the four cores studied contain a mixed Pliocene and late Miocene nannoflora. Table 2 shows the stratigraphic distribution of the calcareous nannofossils at Hole 519A.

\section{Pliocene}

The NN16 Discoaster surculus/NN15 Reticulofenestra pseudoumbilica Zone boundary occurs between Sample 519A-1,CC and Section 519A-2-1. This boundary is recognized by the last occurrence of $R$. pseudoumbilica. Immediately below Section 519A-2-1 the sediments are slumped, and a mixed late Miocene and Pliocene nannoflora is visible.

\section{Hole 520}

Hole 520 was drilled on the Mid-Atlantic Ridge at $25^{\circ} 31.40^{\prime} \mathrm{S}, 11^{\circ} 11.14^{\prime} \mathrm{W}$ in $4217 \mathrm{~m}$ of water. Thirtyone rotary cores were taken in $449 \mathrm{~m}$ of sediment. The Pleistocene and Pliocene sections were spot cored and the Miocene was continuously cored. The sediments range in age from Pleistocene to middle Miocene. The hole is located on the younger boundary of Anomaly 5B (Epoch 15). The oldest calcareous nannofossil zone recovered is the NN5 Sphenolithus heteromorphus Zone*, which correlates with Anomaly 5B or Epoch 15 . Table 3 shows the stratigraphic distribution of the calcareous nannofossils at Hole 520.

\section{Pleistocene}

In the interval from Sample 520-1,CC to 520-2,CC the NN19 Pseudoemiliania lacunosa Zone is present. $P$. lacunosa is very abundant, and Discoaster brouweri is absent. 


\section{Pliocene}

The top of Core 3 is assigned to the NN16 Discoaster surculus Zone on the basis of the occurrence of $D$. brouweri, $D$. pentaradiatus, and $D$. surculus. The bottom of Core 4 is interpreted to be the early Pliocene NN15 Reticulofenestra pseudoumbilica Zone. $R$. pseudoumbilica is present. The NN14 D. asymmetricus Zone occurs from Section 520-5-1 to Sample 520-6,CC, as indicated by the concurrence of Amaurolithus tricorniculatus and $D$. asymmetricus.

\section{Miocene}

The next zone encountered is the NN12 Amaurolithus tricorniculatus Zone*, which is in the upper part of Section 520-8-2. It is recognized by the absence of Ceratolithus rugosus and Discoaster quinqueramus. This section is placed in the lower part of NN12, as indicated by the presence of $A$. amplificus. The interval from the lower part of Section 520-8-2 to Section 520-26-2 is placed in the NN11 $D$. quinqueramus Zone. The total range of $D$. quinqueramus defines this zone. The absence of $D$. quinqueramus and Catinaster calyculus correlates to the interval from Sample 520-26, CC to 520$29-1,10-11 \mathrm{~cm}$; that is, to the NN10 D. calcaris Zone*. The interval from Sample 520-29-1, 20-21 cm to 520$29-1,110-111 \mathrm{~cm}$ is interpreted as the NN8 C. coalitus/ NN10 D. calcaris Zone* undifferentiated on the basis of the occurrence of $C$. calyculus and $C$. coalitus. The interval from Sample 520-29-1, 120-121 cm to 520-29-1, $138-139 \mathrm{~cm}$ represents the NN7 D. kugleri/NN8 C. coalitus Zone* undifferentiated because of the absence of $D$. kugleri and C. coalitus. D. kugleri is present in the interval from Sample 520-29-1, 140-141 cm to 520-29-1, $149-150 \mathrm{~cm}$. This interval is interpreted to belong to the NN7 D. kugleri Zone*. The NN6 D. exilis Zone* is recognized by the occurrence of $D$. deflandrei between Sample 520-29-2, $0 \mathrm{~cm}$ and 520-29-2, 49-50 cm. The NN5 Sphenolithus heteromorphus Zone occurs from Sample $520-29-2,60-62 \mathrm{~cm}$ to $520-30-1,50-51 \mathrm{~cm}$ on the basis of the occurrence of $S$. heteromorphus. The base of this zone was not reached.

\section{Hole 521}

Hole 521 was drilled on the Mid-Atlantic Ridge at $26^{\circ} 04.45^{\prime} \mathrm{S}, 10^{\circ} 15.87^{\prime} \mathrm{W}$ in $4141 \mathrm{~m}$ of water. Twentyone hydraulic piston cores were taken continuously in $84 \mathrm{~m}$ of sediment to basement. Almost all samples contain a very abundant, moderately well to well preserved calcareous nannoflora. However, the last five cores contain a poorly preserved nannoflora. The sediments range in age from Pleistocene to middle Miocene. The hole was located on Anomaly 5C (Epoch 16), with an assumed age of $17 \mathrm{~m} . \mathrm{y}$. The oldest nannofossil zone recognized is the NN4 Helicosphaera ampliaperta Zone*, which correlates with Epoch 16. Table 4 shows the stratigraphic distribution of the calcareous nannofossils at Hole 521.

\section{Pleistocene}

The sample from Section 521-1-1 represents the NN20 Gephyrocapsa oceanica Zone, as indicated by the absence of both Emiliania huxleyi and Pseudoemiliania lacunosa. The interval from Section 521-1-2 to 521-4-1 is assigned to the NN19 $P$. lacunosa Zone. The nominate species is very abundant in this interval.

\section{Pliocene}

Discoaster brouweri is very abundant from Section $521-4-2$ to $521-5-2$ and is indicated as the NN18 $D$. brouweri Zone. The top of the next zone, the NN17 $D$. pentaradiatus Zone, is characterized by the last occurrence of $D$. pentaradiatus, as seen in Section 521-5-3. The NN16 D. surculus Zone is present from Sample $521-5, C C$ to Section 521-9-2, where $D$. surculus Zone is very abundant. $D$. tamalis and $D$. asymmetricus have their extinction near the top of Section 521-6-3. The interval from Section 521-9-3 to 521-10-2 is assigned to the NN14 D. asymmetricus/NN15 Reticulofenestra pseudoumbilica Zone* undifferentiated because the NN14/ NN15 boundary species Amaurolithus tricorniculatus is so rare. $R$. pseudoumbilica and $D$. asymmetricus are also present in this interval. The absence of the latter species and the presence of Ceratolithus rugosus defines the NN13 C. rugosus Zone for the interval from Section 521-10-3 to 521-11-2.

\section{Miocene}

Amaurolithus amplificus defines the lower (Miocene) part of the NN12 A. tricorniculatus Zone, which spans the interval from Section 521-11-2 to 521-11-3. Sample 521-11,CC correlates with the NN11 Discoaster quinqueramus Zone* on the basis of the occurrence of $D$. quinqueramus. The interval from Section 521-12-1 to Sample 521-13,CC represents the NN11 Zone*, which is characterized by the presence of $D$. surculus and absence of Catinaster calyculus. The NN8 C. coalitus/ NN10 $D$. calcaris Zone* undifferentiated is identified from Section 521-14-1 to Sample 521-14,CC by the presence of $C$. calyculus and $C$. coalitus. The last occurrence of $D$. deflandrei characterizes the top of the NN6 D. exilis Zone*. This zone occurs from Section 521-16-1 to Sample 521-16,CC. The NN5 Sphenolithus heteromorphus Zone* is found from Section 521-17-1 to 521-20-3. $S$. heteromorphus is abundant throughout this interval. Samples 521-20,CC and 521-21,CC represent the NN4 Helicosphaera ampliaperta Zone*, as indicated by the last occurrence of $H$. euphratis. The base of this zone was not reached.

\section{Hole 521A}

Hole 521A was drilled on the Mid-Atlantic Ridge at $26^{\circ} 04.54^{\prime} \mathrm{S}, 10^{\circ} 15.59^{\prime} \mathrm{W}$ (southeast of Hole 521) in $4125 \mathrm{~m}$ of water. Seventeen hydraulic piston cores were taken continuously in $71.1 \mathrm{~m}$ of sediment. All sediments except the bottom six cores contain a very abundant, moderately well preserved calcareous nannoflora. The bottom six cores contain a very abundant, poorly preserved nannoflora. Sediments range in age from Pleistocene to middle Miocene. This hole was located on Anomaly $5 \mathrm{C}$. As at Hole 521, the calcareous nannofossil zone (NN4 Helicosphaera ampliaperta Zone) agrees with the paleomagnetic stratigraphy. Table 5 shows the stratigraphic distribution of the calcareous nannofossils at 
Hole 521A. Only core-catcher samples were examined by the author, but a detailed shore-based study was carried out by von Salis (this vol.).

\section{Pleistocene}

The interval from Sample 521A-1,CC to 521A-3,CC represents the NN19 Pseudoemiliania lacunosa Zone, as indicated by the abundant occurrence of $P$. lacunosa.

\section{Pliocene}

The NN17 Discoaster pentaradiatus Zone occurs in Sample 521A-5,CC, where the nominate species is common. The interval from Sample 521A-6,CC to 521A$7, \mathrm{CC}$ is assigned to the NN16 D. surculus Zone. The top of this zone is recognized by the last occurrence of D. surculus. In Sample 521A-8,CC, the early Pliocene NN14 D. asymmetricus/NN15 Reticulofenestra pseudoumbilica Zone* undifferentiated was found. The sample contains diagnostic species, such as $R$. pseudoumbilica and D. asymmetricus but lacks Amaurolithus tricorniculatus, the NN14/NN15 boundary species. The NN13 Ceratolithus rugosus Zone was found in Sample 521A9, CC. C. rugosus occurs frequently, and the NN14 marker species, $D$. asymmetricus, is absent.

\section{Miocene}

The Miocene/Pliocene boundary is placed at the extinction of Amaurolithus amplificus in the NN12 A. tricorniculatus Zone*, which occurs in Sample 521A$10, \mathrm{CC}$. The NN10 Discoaster calcaris Zone*, which occurs in Sample 521A-11,CC, is characterized by the absence of $D$. quinqueramus. Sample 521A-12,CC correlates with the NN9 $D$. hamatus/NN10 $D$. calcaris Zone* undifferentiated on the basis of the occurrence of $D$. prepentaradiatus. Sphenolithus heteromorphus, the species used for the top of the NN5 S. heteromorphus Zone*, is present in the core-catcher samples from Cores 13 to 16. Sample 521A-17,CC contains Helicosphaera euphratis, which is the secondary index species for the NN4 $H$. ampliaperta Zone*.

\section{Hole 522}

Hole 522 was drilled on the Mid-Atlantic Ridge at $24^{\circ} 06.843^{\prime} \mathrm{S}, 05^{\circ} 07.784^{\prime} \mathrm{W}$ in $4441 \mathrm{~m}$ of water. Thirtynine hydraulic piston cores were taken continuously in $148.7 \mathrm{~m}$ of sediment. Basement was not reached. Samples from Cores 1 to 12 contain a moderately well to well preserved, very abundant calcareous nannoflora. Cores 13 through 39 contain poorly preserved nannofossils. Sediments range in age from Pleistocene to late Eocene. The hole was located on Anomaly 16. The oldest calcareous nannofossil zone recognized was the NP20 Sphenolithus pseudoradians Zone, which is in agreement with Anomaly 16. Two Braarudosphaera chalk horizons found at this site are assigned to the NP23 S. predistentus Zone. Some Pliocene mixing with Pleistocene occurs in Cores 1 through 3. Table 6 shows the stratigraphic distribution of the calcareous nannofossils from Hole 522.

\section{Pleistocene}

The sample from Section 522-1-1 represents the NN20 Gephyrocapsa oceanica Zone. This sample lacks Pseudoemiliania lacunosa and Emiliania huxleyi. The occurrence of $P$. lacunosa in the interval from Section 522-1-2 to Sample 522-3,CC assigns this interval to the NN19 P. lacunosa Zone. Sediments from the late Pliocene NN18 Discoaster brouweri Zone are intermixed with NN19 in this interval.

\section{Pliocene}

Discoaster brouweri is present in the sample from Section 522-4-1, which indicates the NN18 $D$. brouweri Zone. The interval from Section 522-4-3 to Sample $522-6, C C$ is NN16 D. surculus Zone in age. Very abundant $D$. surculus, $D$. brouweri, and $D$. pentaradiatus are found in this interval. $D$. tamalis has its last occurrence in the sample from Section 522-5-2. The early Pliocene NN15 Reticulofenestra pseudoumbilica Zone is found from Section 522-7-2 to Sample 522-8,CC. $R$. pseudoumbilica, the marker species for NN15, is very abundant throughout this interval. The only occurrence of Amaurolithus tricorniculatus characterizes the top of the NN14 D. asymmetricus Zone, which occurs in Section 522-9-1. The NN13 Ceratolithus rugosus Zone is present from Section 522-9-2 to 522-9-3. This interval is characterized by the occurrence of $C$. rugosus and absence of $D$. asymmetricus.

\section{Miocene}

The Miocene/Pliocene boundary is placed within the NN11 Discoaster quinqueramus/NN12 Amaurolithus tricorniculatus Zone*, which is found in Sample 5229,CC. The first occurrence of $A$. primus and $A$. delicatus define the base of the zone in Section 522-10-1. The NN11 D. quinqueramus Zone* is found in Section 522-10-3 after an indeterminate interval at 522-10-2. The first appearance of the secondary marker species, $D$. surculus, is encountered in Section 522-10-3. The interval from Sample $522-10, C$ C to Section $522-12-1$ is barren of calcareous nannofossils, so that the lower limit of NN11 cannot be determined with certainty. The total range of Sphenolithus heteromorphus is used to define the NN3 $S$. belemnos/NN5 $S$. heteromorphus Zone* from Section 522-12-2 to Sample 522-13,CC. Similarly, the total range of $D$. druggi is used to define the NN2 $D$. druggi/NN3 $S$. belemnos Zone* from Section 522-14-1. The NN1 Triquetrorhabdulus carinatus Zone* is recognized by the absence of $D$. druggi and Oligocene species, such as Dictyococcites bisectus or $D$. scrippsae. This zone is found from Section 522-14-2 to 522-15-1.

\section{Oligocene}

The Oligocene/Miocene boundary is defined herein as the top of the NP25 Sphenolithus ciperoensis Zone*, which is recognized by the last occurrence of Dictyococcites bisectus. The extinction of $S$. distentus characterizes the top of the NP24 S. distentus Zone. The NP25 
Zone covers the interval from Section 522-15-2 to 522-20-2. The concurrence of $S$. ciperoensis and $S$. distentus throughout the interval from Sample 522-20,CC to Section 522-22-3 restricts this section to the NP24 S. distentus Zone*. The occurrences of $S$. distentus above Sample 522-20,CC are considered reworked. The NP23 $S$. predistentus Zone* can be distinguished by the absence of S. ciperoensis and the last occurrence of Reticulofenestra umbilica at its base. This zone covers the interval from Sample 522-22,CC to Section 522-31-2. Two horizons of Braarudosphaera chalk were encountered in Cores 23 and 25. From Section 522-31-3 to 522-32-3 the NP22 Helicosphaera reticulata Zone is found. It contains $R$. umbilica. The NP21 Ericsonia subdisticha Zone is recognized from Sample 522-32,CC to Section 522-36-3. Coccolithus formosus has its last occurrence at the top of the NP21 Zone.

\section{Eocene}

The Eocene/Oligocene boundary is characterized by the last appearance of Discoaster saipanensis, which marks the top of the NP20 Sphenolithus pseudoradians Zone. This horizon occurs in Sample 522-36,CC. The NP20 Zone continues down to Sample 522-39,CC.

\section{Hole 522A}

Hole 522A was drilled on the Mid-Atlantic Ridge at $26^{\circ} 06.843^{\prime} \mathrm{S}, 05^{\circ} 07.784^{\prime} \mathrm{W}$ to recover a complete Oligocene/Eocene section for future paleomagnetic and paleontologic studies. The hole was drilled in $4441 \mathrm{~m}$ of water. Thirty-one hydraulic piston cores were taken continuously from early Miocene to basement. All samples contain a poorly preserved, very abundant calcareous nannoflora. The oldest calcareous nannofossil zone recognized is the NP20 Sphenolithus pseudoradians Zone, which correlates with Anomaly 16. This is in agreement with the paleomagnetic record, which determined the site to be on Anomaly 16. Two layers of Braarudosphaera chalk were encountered in the NP23 S. predistentus Zone. Table 7 shows the stratigraphic distribution of the calcareous nannofossils at Hole 552A. Most of the samples examined from this site were corecatcher samples.

\section{Miocene}

Sample 522A-1,CC is assigned to the NN6 Discoaster exilis Zone* on the basis of the occurrence of $D$. deflandrei. The interval from Sample 522A-2,CC to $522 \mathrm{~A}-3-1,20-21 \mathrm{~cm}$, is assigned to the NN1 Triquetrorhabdulus carinatus Zone*, which is defined by the last occurrence of Coccolithus eopelagicus.

\section{Oligocene}

The extinction datum of Dictyococcites bisectus defines the top of the Oligocene. The presence of this species without Sphenolithus distentus from Sample $522 \mathrm{~A}-3-1,60-61 \mathrm{~cm}$ to $522 \mathrm{~A}-4, \mathrm{CC}$ indicates the NP25 $S$. ciperoensis Zone. The interval from Sample 522A$5, \mathrm{CC}$ to $522 \mathrm{~A}-9, \mathrm{CC}$ is designated the NP24 S. distentus Zone on the basis of the occurrence of S. distentus. The very rare occurrences of $S$. distentus in the core-catcher samples from Cores 5 to 6 are considered reworked, which would lower the NP24/25 boundary to the corecatcher sample from Core 7. This is more in keeping with the interpretation of Hole 522. The first appearance of $S$. ciperoensis defines the top of the NP23 S. predistentus Zone. This species first appears in Sample 522A-9,CC. The NP23 zonal assignment continues from the core-catcher samples from Cores 10 to 18 . Two Braarudosphaera chalk horizons were encountered in NP23 in Cores 11 and 12. The NP22 Helicosphaera reticulata Zone is characterized by the occurrence of Reticulofenestra umbilica. This form is seen in core-catcher samples from Cores 19 to 20. The last occurrence of Coccolithus formosus defines the top of the NP21 Ericsonia subdistcha Zone, which ranges from Sample 522A$22, \mathrm{CC}$ to $522 \mathrm{~A}-27, \mathrm{CC}$.

\section{Eocene}

The Eocene/Oligocene boundary is placed at Section 522A-28-1 on the basis of the extinction horizon of Discoaster saipanensis, which designates the top of the NP20 Sphenolithus pseudoradians Zone. This zone extends downward at least to Sample 522A-31,CC, the lowermost sample examined.

\section{Hole 522B}

Hole 522B was drilled on the Mid-Atlantic Ridge at $26^{\circ} 06.843^{\prime} \mathrm{S}, 05^{\circ} 07.784^{\prime} \mathrm{W}$ to recover basalt. It was drilled in $4441 \mathrm{~m}$ of water. Only three rotary cores were taken in sediments and three in basalt. The sediments contain a poorly preserved very abundant calcareous nannoflora. The sediments range in age from Oligocene to Eocene. The oldest nannofossil zone recovered is the NP20 Sphenolithus pseudoradians Zone, which is in agreement with the paleomagnetic pattern of Anomaly 16. Table 8 shows the distribution of calcareous nannofossils at Hole 522B.

\section{Oligocene}

The sample from Core 1 is assigned to the NP22 Helicosphaera reticulata Zone, which is characterized by the occurrence of Reticulofenestra umbilia without Coccolithus formosus.

\section{Eocene}

The next two cores, Cores 2 and 3, contain Discoaster saipanensis, which characterizes the late Eocene NP20 Sphenolithus pseudoradians Zone.

\section{Hole 523}

Hole 523 was drilled on the Mid-Atlantic Ridge at $28^{\circ} 33.131^{\prime} \mathrm{S}, 02^{\circ} 15.078^{\prime} \mathrm{W}$ in $4573 \mathrm{~m}$ of water. Fiftyone hydraulic piston cores were taken in $190.5 \mathrm{~m}$ of sediment. The calcareous nannoflora was moderately well preserved and very abundant. Sediments range in age from Pleistocene to Eocene. The site is located on Anomaly 21 . The oldest sediment recovered represents the NP15 Nannotetrina fulgens Zone*, which correlates with Anomaly 20. The apparent discrepancy results from the failure to recover sediment immediately above basalt. Two Braarudosphaera chalk horizons were cored 
Zone*. Table 9 shows the stratigraphic distribution of calcareous nannofossils at Hole 523.

\section{Pleistocene}

The samples from Sample 523-1,CC to Section 523-3-1 are assigned to the NN19 Pseudoemiliania lacunosa Zone. $P$. lacunosa is very abundant throughout this interval.

\section{Pliocene}

The NN18 Discoaster brouweri Zone occurs from Section 523-3-2 to Sample 523-3,CC. This zone is characterized by the occurrence of the nominate species. From Section 523-4-2 to 523-6-2, the $D$. surculus Zone is found, on the basis of the occurrence of $D$. surculus. $D$. tamalis has its last occurrence near the top of the zone. The occurrence of Reticulofenestra pseudoumblica defines the NN15 $R$. pseudoumbilica Zone. It occurs from Section 523-6-3 to 523-7-3. Sample 523-7,CC represents the NN14 D. asymmetricus Zone on the basis of the concurrence of $D$. asymmetricus and Amaurolithus tricorniculatus.

\section{Miocene}

The Miocene/Pliocene boundary is placed within the interval assigned to the NN11 Discoaster quinqueramus/NN12 Amaurolithus tricorniculatus Zone* undifferentiated which is indicated by the absence of Ceratolithus rugosus and presence of $A$. delicatus. This zone is found from Section 523-8-1 to Sample 523-10,CC. The NN11 $D$. quinqueramus Zone is characterized by the occurrence of $D$. surculus without Amaurolithus spp. as seen in Section 523-11-1. The concurrence of $D$. deflandrei and D. brouweri in Section 523-11-2 indicates the NN4 Helicosphaera ampliaperta/NN6 D. exilis Zone. The NN1 Triquetrorhabdulus carinatus Zone is found from Section 523-11-3 to Sample 523-11,CC on the basis of the occurrence of Coccolithus eopelagicus without typical Oligocene species.

\section{Oligocene}

The Oligocene/Miocene boundary is placed within Section 523-12-1 on the occurrence of Dictyococcites bisectus, which defines the top of NP25 Sphenolithus ciperoensis Zone*. This zone continues down to Sample 523-14,CC. S. distentus, which is the marker species for the NP24 S. distentus Zone*, is found in Sample 523-15, $C C$. The last occurrence of $S$. pseudoradians defines the top of the NP23 S. predistentus Zone*, as seen in Sample 523-17,CC. The interval from Sample 523-17,CC to Section 523-24-1 is assigned to the NP23 Zone. Two Braarudosphaera chalk horizons were encountered in the NP23 Zone in Cores 18 and 19. The presence of Reticulofenestra umbilica from Sections 523-24-3 to 523-25-1 indicates the NP21 Helicosphaera reticulata Zone. The basal Oligocene NP21 Ericsonia subdisticha Zone is encountered from Section 523-25-2 to Sample 523-27, CC on the basis of the occurrence of Coccolithus formosus.

\section{Eocene}

The Eocene/Oligocene boundary is placed at the extinction datum of Discoaster saipanensis at Section 523-28-1. This species characterizes the NP20 Sphenolithus pseudoradians Zone, which continues down to Sample 523-28,CC, where $S$. pseudoradians first occurs. The first appearance of Isthmolithus recurvus in Sample 523-29,CC indicates the NP19 $I$. recurvus Zone. The NP18 Chiasmolithus oamaruensis Zone* occurs from Section 523-30-1 to Sample 523-31,CC on the basis of the last occurrence of $C$. grandis in Section 523-32-1. The NP17 D. saipanensis Zone* is characterized by the absence of $C$. solitus. This zone ranges from Section 523-32-1 to Sample 523-37,CC. The NP16 D. tani nodifer Zone is found from Sections 523-38-1 to 523-42-2 on the basis of the occurrence of $C$. solitus and the absence of Nannotetrina fulgens. The location of the NP15 N. fulgens/NP16 D. tani nodifer Zone* boundary is impossible to determine because of the absence of $R h a b$ dolithus gladius, the extinction of which defines the boundary. Therefore, the last occurrence of $N$. fulgens is used to define the NP15/NP16 Zone* undifferentiated, which covers the interval from Section 523-42-3 to Sample 523-45,CC. A definite NP15 N. fulgens Zone* is found from Section 523-46-1 to Sample 523-50,CC on the basis of the occurrence of $C$. gigas.

\section{Hole 524}

Hole 524 was drilled on the Walvis Ridge at $29^{\circ}$ $29.055^{\prime} \mathrm{S}, 03^{\circ} 30.741^{\prime} \mathrm{E}$ in $4796 \mathrm{~m}$ water. Thirty-nine rotary cores were taken in $348.5 \mathrm{~m}$ of sediment, and six were taken in basalt.

Coring was continuous below the top of the Paleocene. Most samples contain a poor to moderately well preserved, very abundant calcareous nannoflora. The sediments range in age from Late Cretaceous to early Eocene. The hole was drilled on a magnetic quiet zone of probable Turonian age. Since we did not drill to basement, the paleontology cannot be correlated with the paleomagnetic pattern. Table 10 shows the stratigraphic distribution of calcareous nannofossils from Hole 524 .

\section{Eocene}

The sample from Core 1 encountered the NP12 Tribrachiatus orthostylus Zone, which is characterized by the occurrence of $T$. orthostylus and Discoaster lodoensis. The samples from Core 2 are assigned to the NP11 $D$. binodosus Zone because of the absence of $D$. lodoensis and $D$. multiradiatus. Core 3 contains $D$. multiradiatus and was assigned to the NN10 T. contortus Zone.

\section{Paleocene}

The Paleocene/Eocene boundary is placed between Sample 524-3,CC and Section 524-4-1. The extinction datum of Discoaster mohleri is used to define this boundary. The presence of Discoaster mohleri with $D$. multiradiatus indicates the NP9 D. multiradiatus Zone. This zone occurs in the interval from Section 524-4-1 to 524-5-4. The absence of $D$. multiradiatus defines the 
NP8 D. mohleri Zone*, which ranges from Section 524-5-5 to 524-6-3. The NP7 Heliolithus riedeli Zone* is characterized by the last occurrence of $H$. kleinpellii at its top and the first appearance of $D$. mohleri at its base. This zone is only identified in Sample 524-6,CC. The NP6 H. kleinpellii Zone occurs in Core 7 and is identified by the first appearance of $H$. kleinpellii at its base. The presence of Fasciculithus tympaniformis and the absence of $\mathrm{H}$. kleinpellii characterize the NP5 F. tympaniformis Zone, as is seen from Section 524-8-1 to 524-10-4. The NP4 E. macellus Zone is defined by the absence of $\boldsymbol{F}$. tympaniformis and the first appearance of E. macellus at its base. It is found from Section 524-10-5 to 524-11-6. The base of the next zone, the NP3 Chiasmolithus danicus Zone, is determined by the first appearance of the nominate species. This form first occurs in Section 524-17-4, and the zone ranges from Sample 524-11,CC to Section 524-17-4. The first appearance of Cruciplacolithus edwardsii is used herein to define the base of the NP2 $C$. edwardsii Zone*. This horizon is found in Sample 524-19,CC. The lowest Tertiary zone is the NP1 Markalius astroporus Zone. Its base is identified by the first appearance of Zygodiscus sigmoides. This zone occurs from Sample 524-20-1, 9-10 cm to $524-20-3,106 \mathrm{~cm}$. The Cretaceous/Tertiary boundary will be discussed in more detail below.

\section{Cretaceous}

Defining the Cretaceous/Tertiary boundary is very difficult because of a long section of mixed Maestrichtian and Danian calcareous nannofossils. Oxygen-isotope work by Hsü et al. (1982) on these samples indicates that the Cretaceous forms are in place and not reworked, as is the normal interpretation. This author decided to use the first occurrence of Zygodiscus sigmoides to define the Cretaceous/Tertiary boundary. This boundary agrees well with the iridium concentration horizon that occurs in Sample 524-20-3, $106 \mathrm{~cm}$ (Hsü et al., 1982). The Micula mura Zone as herein defined has none of the typical Danian forms, such as $Z$. sigmoides, Thoracosphaera operculata, Markalius astroporus, Biantholithus sparsus, and Neochiastozygus concinnus. The base of the Micula mura Zone is characterized by the first occurrence of $M$. mura. This zone covers the interval from Sample 524-20-1, 108-109 cm to Section 524-26-5. It is interesting that Nephrolithus frequens, the zonal marker for the next zone $(N$. frequens Zone), occurs throughout this zone. The first occurrence of $N$. frequens is at Section 524-28-5. The interval from Sample 524-28, CC to 524-35, CC cannot be zoned because of poor preservation and a decrease in diversity. Therefore, the interval is assigned to the Nondiagnostic Zone on the basis of the occurrence of $M$. staurophora, which ranges from late Turonian to Maestrichtian.

\section{Hole 524A}

Hole 524A was drilled on the Walvis Ridge at $29^{\circ} 29.055^{\prime} \mathrm{S}, 03^{\circ} 30.741^{\prime} \mathrm{E}$ in $4805 \mathrm{~m}$ of water. Two rotary cores were taken in sediments that contain moderately well preserved, very abundant calcareous nanno- fossils. The sediments range in age from Eocene to $\mathrm{Pa}$ leocene. Table 11 shows the stratigraphic distribution of the calcareous nannofossils from Hole 524A.

\section{Eocene}

The NP10 Tribrachiatus contortus Zone* is found from Section 524A-1-1 to Section 524A-2-2 on the basis of the occurrence of Discoaster multiradiatus without Paleocene marker species.

\section{Paleocene}

The Paleocene/Eocene boundary occurs at Sample 524A-2,CC. This is the top of the NP9 Discoaster multiradiatus Zone*, which is defined by the occurrence of Fasciculithus involutus with D. multiradiatus.

\section{Hole 524B}

Hole 524B was drilled on the Walvis Ridge at $29^{\circ} 29.07^{\prime} \mathrm{S}, 03^{\circ} 30.7^{\prime} \mathrm{E}$ in $4805 \mathrm{~m}$ of water. Seven hydraulic piston cores were taken in sediments that contain a moderately well preserved, very abundant calcareous nannoflora. The sediments are early Eocene in age. Table 12 shows the stratigraphic distribution of the calcareous nannofossils at Hole 524B.

\section{Eocene}

Section $524 \mathrm{~B}-1-1$ is assigned to the early Eocene NP13 Discoaster lodoensis Zone on the basis of the occurrence of $D$. lodoensis and the absence of Tribrachiatus orthostylus. The occurrence of these two species from Section 524B-1-2 to 524B-3-2 indicates the NP12 T. orthostylus Zone. Apparently NP11 is missing, because the next zone is the NP10 T. contortus Zone*. NP10* is distinguished by the occurrence of $D$. multiradiatus and the absence of Paleocene marker species and is identified from Section 524B-3-3 to Sample 524B-7, CC.

\section{ACKNOWLEDGMENTS}

The author wishes to thank Dr. David Bukry, U.S. Geological Survey, La Jolla, California, and Mr. C. Howard Ellis, Sohio Petroleum Company, San Francisco, California, for their constructive criticism of this paper. He also wishes to thank Messrs. Rodolfo T. Guerra, Ronald W. Morin, and Stephan Root of Mobil Exploration and Producing Services, Dallas, Texas for their suggestions.

\section{REFERENCES}

Bukry, D., 1973. Low-latitude coccolith biostratigraphic zonation. In Edgar, N. T., Saunders, J. B., et al., Init. Repts. DSDP, 15: Washington (U.S. Govt. Printing Office), 685-703. 1975. Coccolith and silicoflagellate stratigraphy, northwestern Pacific Ocean, Deep Sea Drilling Project, Leg 32. In Larson, R. L., Moberly, R., et al., Init. Repts. DSDP, 32: Washington (U.S. Govt. Printing Office), 677-701.

Čepek, P., and Hay, W. W., 1969. Calcareous nannoplankton and biostratigraphic subdivision of the Upper Cretaceous. Gulf Coast Assoc. Geol. Soc. Trans., 19:323-336.

Hsü, K. J., He, Q., McKenzie, J. A., Weissert, H., Perch-Nielsen, K., et al., 1982. Mass mortality and its environmental and evolutionary consequences. Science, 216(4543):249-256.

Martini, E., 1969. Nannoplankton aus dem Latdorf (locus typicus) und weltweite Parallelisierungen im oberen Eozan und unteren Oligozan. Senckenbergiana Lethaea, 50:117-159. 1971. Standard Tertiary and Quaternary calcareous nannoplankton zonation. In Farinacci, A. (Ed.), Proc. Second Planktonic Conf.: Rome (Tecnoscienza), 739-785. 
Okada, H., and Bukry, D., 1980. Supplementary modification and introduction of code numbers to the low-latitude coccolith biostratigraphic zonation (Bukry, 1973; 1975). Mar. Micropaleontol., 5: 321-325.

Perch-Nielsen, K., 1977. Albian to Pleistocene calcareous nannofossils from the Western South Atlantic, DSDP Leg 39. In Supko, P. R., Perch-Nielsen, K., et al., Init. Repts. DSDP, 39: Washington (U.S. Govt. Printing Office), 699-823.
Romein, A. J. T., 1979. Lineages in early Paleogene calcareous nannoplankton. Utrecht Micropaleontol. Bull., 15:1-231.

Thierstein, H. R., and Okada, H., 1979. The Cretaceous/Tertiary boundary event in the North Atlantic. In Tucholke, B. E., Vogt, P. R., et al., Init. Repts. DSDP, 43: Washington (U.S. Govt. Printing Office), 601-616.

Date of Initial Receipt: July 29, 1982 
Table 1A. Distribution of calcareous nannofossils in Hole 519, Cores 1 to 14 .

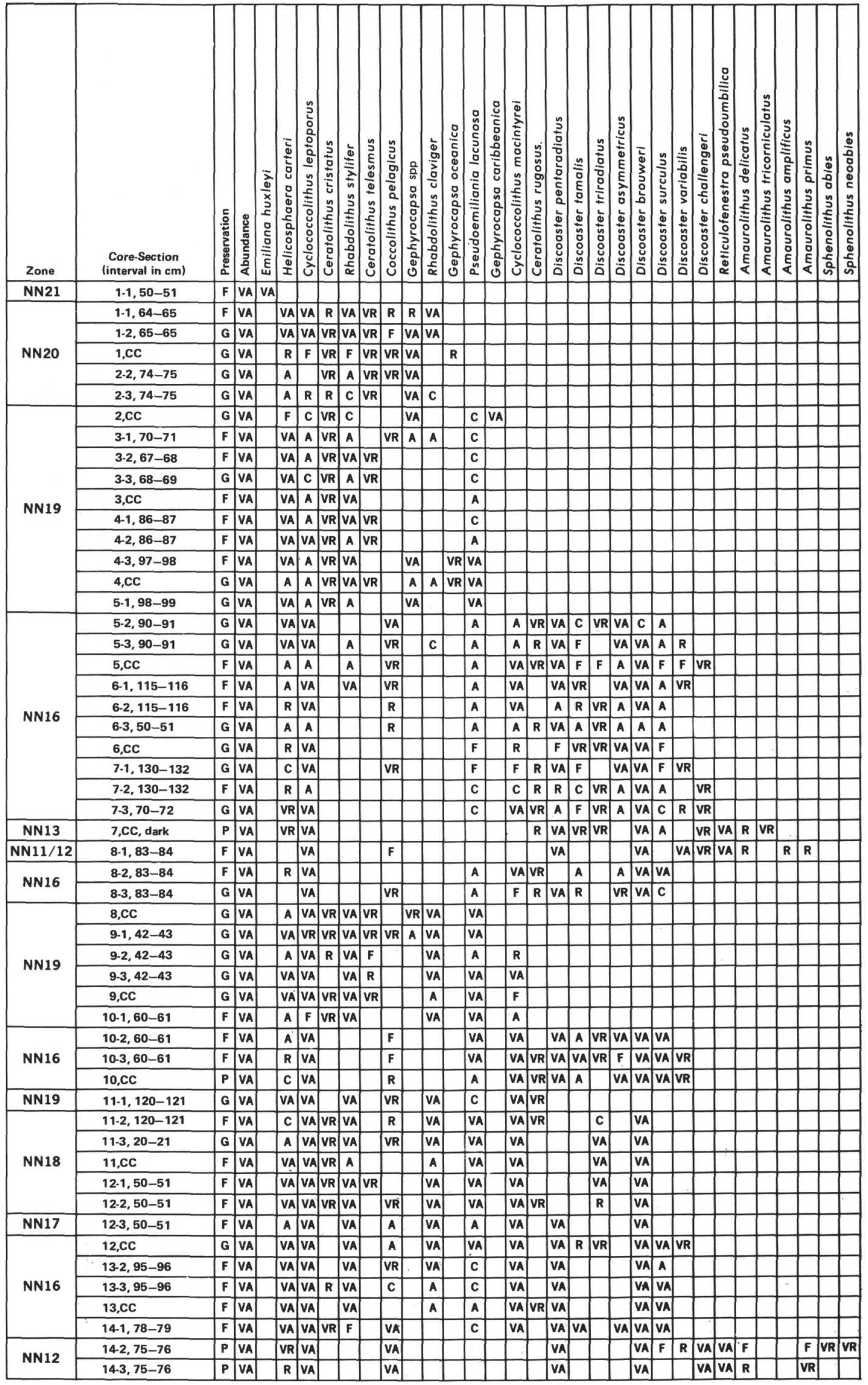


Table 1B. Distribution of calcareous nannofossils in Hole 519, Cores 14 to 29 .

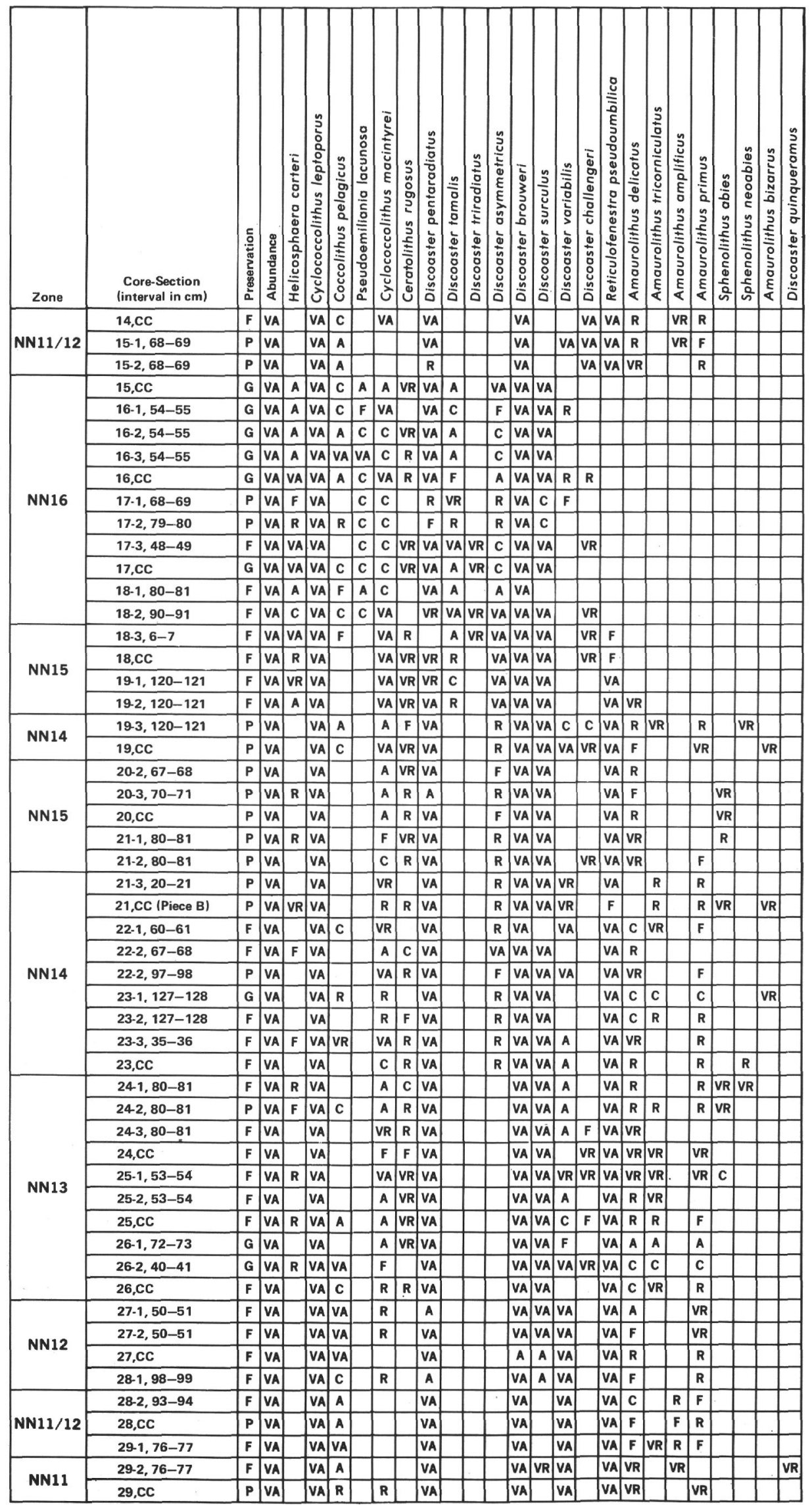


Table 1C. Distribution of calcareous nannofossils in Hole 519, Cores 30 to 36.

\begin{tabular}{|c|c|c|c|c|c|c|c|c|c|c|c|c|c|c|c|c|}
\hline Zone & $\begin{array}{c}\text { Core-Section } \\
\text { (interval in cm) }\end{array}$ & 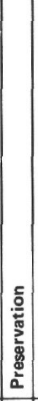 & 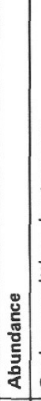 & 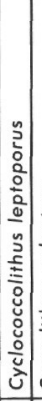 & 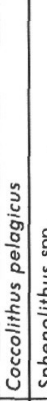 & 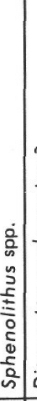 & 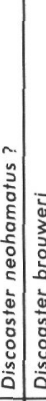 & 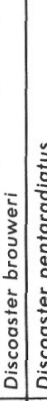 & 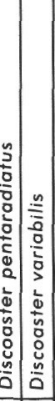 & 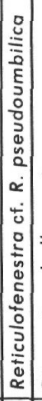 & 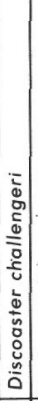 & 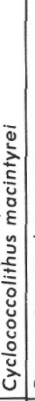 & 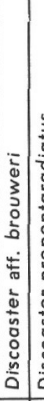 & 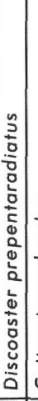 & 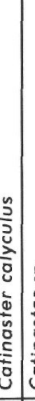 & 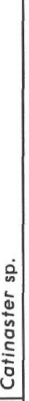 \\
\hline \multirow{13}{*}{ NN10/11 } & $30-1,93-94$ & $\mathbf{P}$ & VA & VA & \begin{tabular}{l|l} 
VA & $F$ \\
\end{tabular} & \begin{tabular}{l|l} 
& $V$
\end{tabular} & VA 1 VI & \begin{tabular}{l|l} 
VA & A \\
\end{tabular} & \begin{tabular}{l|l|}
$A$ & $V A$ \\
\end{tabular} & & & & & & & \\
\hline & $30-2,56-57$ & $\mathbf{F}$ & VA & VA & VA & & VA $\quad$ VA & \begin{tabular}{l|l}
$\mathrm{VA}$ & $\mathrm{V} / \mathrm{I}$ \\
\end{tabular} & $\begin{array}{lll} & V A \\
\end{array}$ & VA I & VR & $\mathrm{R}$ & & & & \\
\hline & $30-3,37-38$ & $\mathbf{F}$ & VA I & VA & VA & & \begin{tabular}{l|l}
$\mathrm{VA}$ & $\mathrm{V} f$ \\
\end{tabular} & \begin{tabular}{l|l} 
VA & $F$ \\
\end{tabular} & \begin{tabular}{|l|l|}
$\mathbf{F}$ & $\mathrm{VA}$ \\
\end{tabular} & & & c & & & & \\
\hline & $30, \mathrm{CC}$ & $\mathbf{P}$ & vali & VA & \begin{tabular}{l|l}
$V A$ & $F$ \\
\end{tabular} & $\mathbf{F}$ & \begin{tabular}{l|l}
$\mathbf{R}$ & $\mathbf{V}$ \\
\end{tabular} & \begin{tabular}{l|l} 
VA & $R$ \\
\end{tabular} & \begin{tabular}{l|l|}
$R$ & VA \\
\end{tabular} & $\mathbf{R}$ & & VA & & & & \\
\hline & $31-1,97-98$ & $\mathrm{P}$ & VA & VA & \begin{tabular}{l|l} 
VA & A \\
\end{tabular} & A 1 & \begin{tabular}{l|l} 
VA & V \\
\end{tabular} & \begin{tabular}{l|l} 
VA & $R$ \\
\end{tabular} & \begin{tabular}{|l|l|}
$\mathbf{R}$ & VA \\
\end{tabular} & $\mathbf{R}$ & & VA & & & & \\
\hline & $31-2,97-98$ & $\mathbf{F}$ & VA & VA & \begin{tabular}{l|l} 
VA & $A$ \\
\end{tabular} & $\mathrm{~A} \mid \mathrm{V}$ & $\begin{array}{lll}V A & V \\
\end{array}$ & VA $\mid V I$ & \begin{tabular}{ll|l} 
& VA & $V A$ \\
\end{tabular} & VA & & VA & & & & \\
\hline & $31-3,104-105$ & $\mathbf{F}$ & VA & VA & & & \begin{tabular}{l|l} 
VR & Vi \\
\end{tabular} & VA VI & VR & VA & & VA & & & & \\
\hline & $31, \mathrm{CC}$ & $\mathrm{F}$ & VA & VA & c & & VR V V & VA & \begin{tabular}{ll|l}
$\mathbb{A}$ & $\mathrm{F}$ \\
\end{tabular} & VA & & c & & & & \\
\hline & $32-1,26-27$ & $\mathbf{F}$ & VA & VA & \begin{tabular}{l|l}
$c$ & $v$ \\
\end{tabular} & VR & & \begin{tabular}{l|l} 
VA & $R$ \\
\end{tabular} & $\begin{array}{l}\mathrm{R} \\
\end{array}$ & VA & & $\mathbf{R}$ & & & & \\
\hline & $32-2,26-27$ & $\mathbf{P}$ & VA & VA & & & \begin{tabular}{l|l} 
VR & V \\
\end{tabular} & VA VI & VR VA & $v A$ & & $c$ & & & & \\
\hline & $32-3,26-27$ & $\mathbf{F}$ & VA & VA & A & & \begin{tabular}{l|l} 
VR & V \\
\end{tabular} & VA VI & \begin{tabular}{l|l}
$R$ & $V A$ \\
\end{tabular} & VA & & & & & & \\
\hline & $32, \mathrm{CC}$ & $\mathbf{F}$ & VA & VA & VA & & VR & & VA & VA & & c 1 & VA & & & \\
\hline & $33-1,68-69$ & $\mathrm{~F}$ & VA & VA & A & & VR & & VA & $\mathrm{VA}$ & & & VA & & & \\
\hline \multirow{14}{*}{ NN10 } & $33-2,45-46$ & $\mathbf{F}$ & VA & VA & A & & & & VA & va & & & VA $V$ & VR & c & \\
\hline & $33-3,63-64$ & $\mathbf{F}$ & VA & VA & & A 1 & VR & & VA & va & & $\mathbf{R}$ & va & & c & \\
\hline & $33, \mathrm{CC}$ & $\mathbf{F}$ & VA & VA & A & & & & VA & VA & & & VA & & VA & \\
\hline & $341,70-71$ & $\mathbf{F}$ & VA 1 & VA & VA & & & & VA & VA & & & C & & VA & \\
\hline & $34-2,70-71$ & $\mathbf{F}$ & VA & VA & $\mathrm{VA}$ & & & & VA & VA & & A & \begin{tabular}{l|l}
$\mathbf{R}$ & $\mathbf{V}$ \\
\end{tabular} & VR & & A \\
\hline & $34-3,25-26$ & $\mathbf{F}$ & VA & VA & A & & & & VA & va & & A & $\mathbf{R}$ & & & c \\
\hline & $34, \mathrm{CC}$ & $\mathbf{F}$ & $\begin{array}{lll}\text { VA } & \text { I } \\
\end{array}$ & VA & VA & & & & VA & $\mathrm{VA}$ & & c & $\mathbf{R}$ & VR & & C \\
\hline & $35-1,80-81$ & $\mathbf{F}$ & VA 1 & VA & VA & & & & VA & VA & & & VR & VR & & C \\
\hline & $35-2,79-80$ & $\mathbf{F}$ & $\mathrm{VA}$ & VA 1 & VA & & & & VA & $\mathrm{VA}$ & & & $\mathbf{R}$ & VR & & C \\
\hline & $35-3,80-81$ & $\mathbf{F}$ & VA & VA & C & & & & VA & VA & $\mathbf{R}$ & & $\mathbf{R}$ & VR & & \\
\hline & $35, \mathrm{CC}$ & $\mathbf{F}$ & VA & VA & A & & & & VA & VA & & & $\mathbf{R}$ & & & \\
\hline & $36-1,71-72$ & $\mathbf{F}$ & VA & VA & A & & & & VA & VA & & & $R$ & $R$ & & \\
\hline & $36-2,55-56$ & $P$ & VA & VA & A & & & & VA & VA & $\mathbf{R}$ & & $\mathbf{R}$ & $\mathrm{R}$ & & \\
\hline & $36, \mathrm{cc}$ & $P$ & val & VA & A & & & & VA & VA & & & $\mathbf{R}$ & VR & & \\
\hline
\end{tabular}


Table 2. Distribution of calcareous nannofossils in Hole 519A.

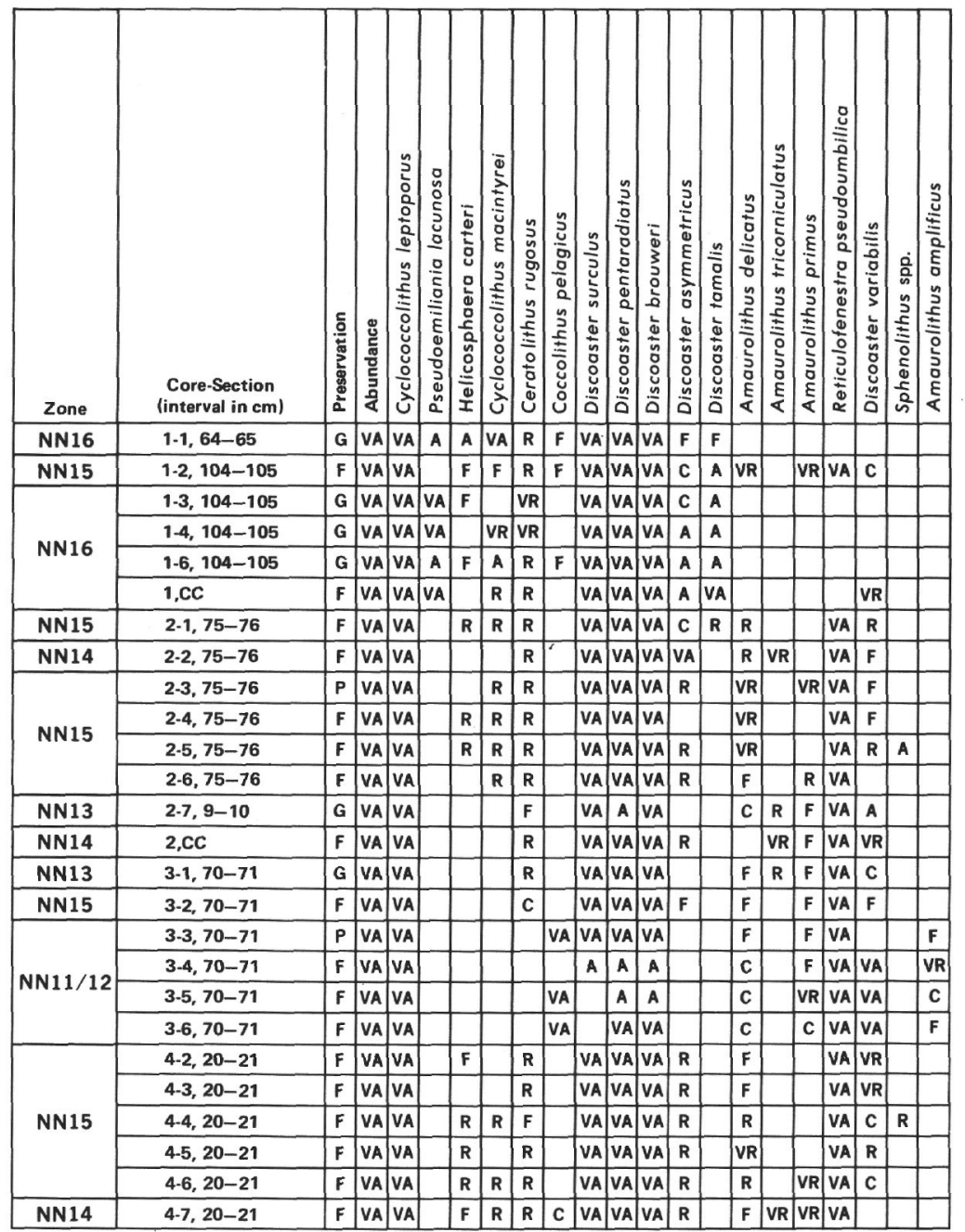


Table 3A. Distribution of calcareous nannofossils in Hole 520, Cores 1 to 23 .

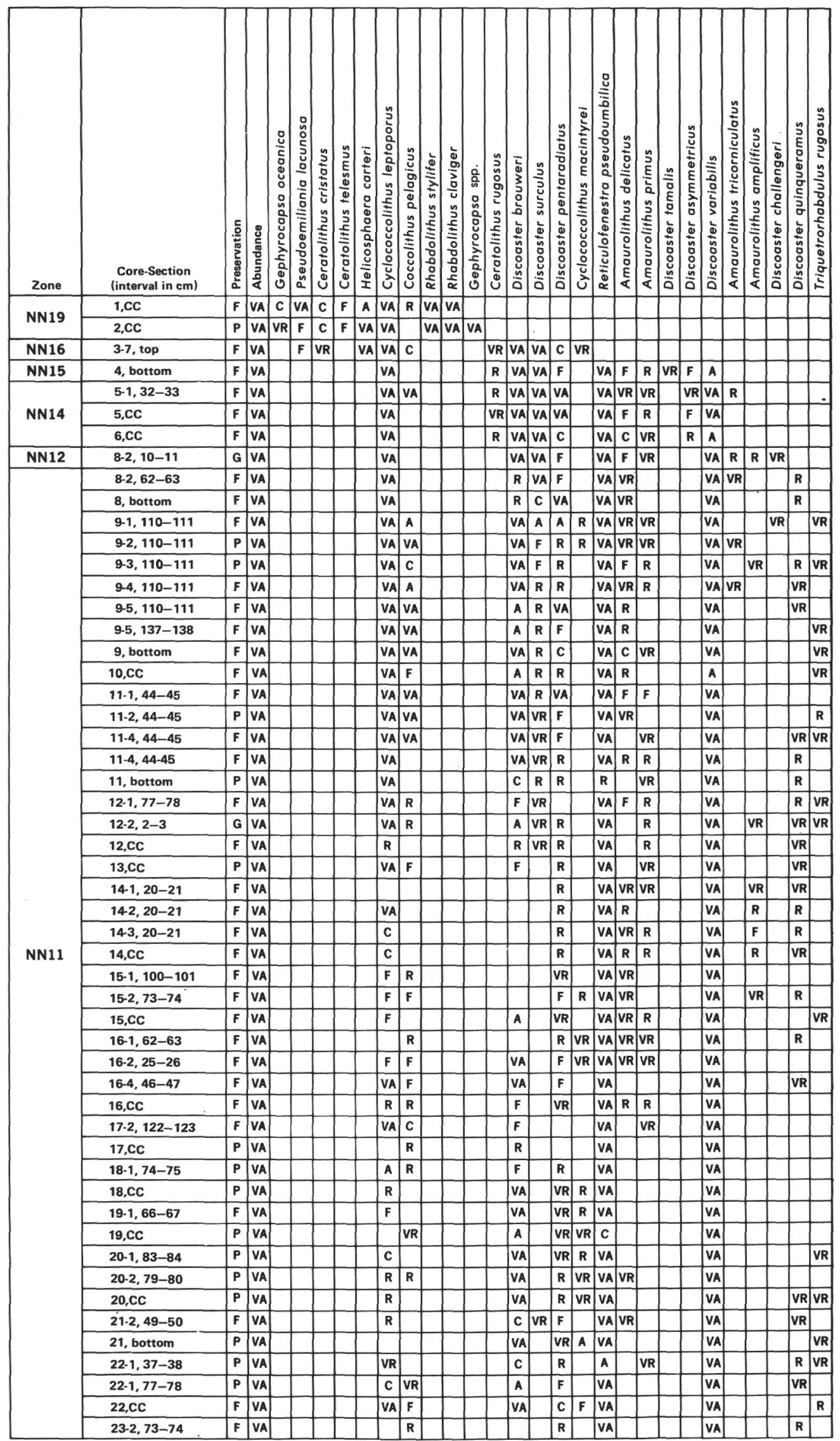


Table 3B. Distribution of calcareous nannofossils in Hole 520, Cores 23 to 30 .

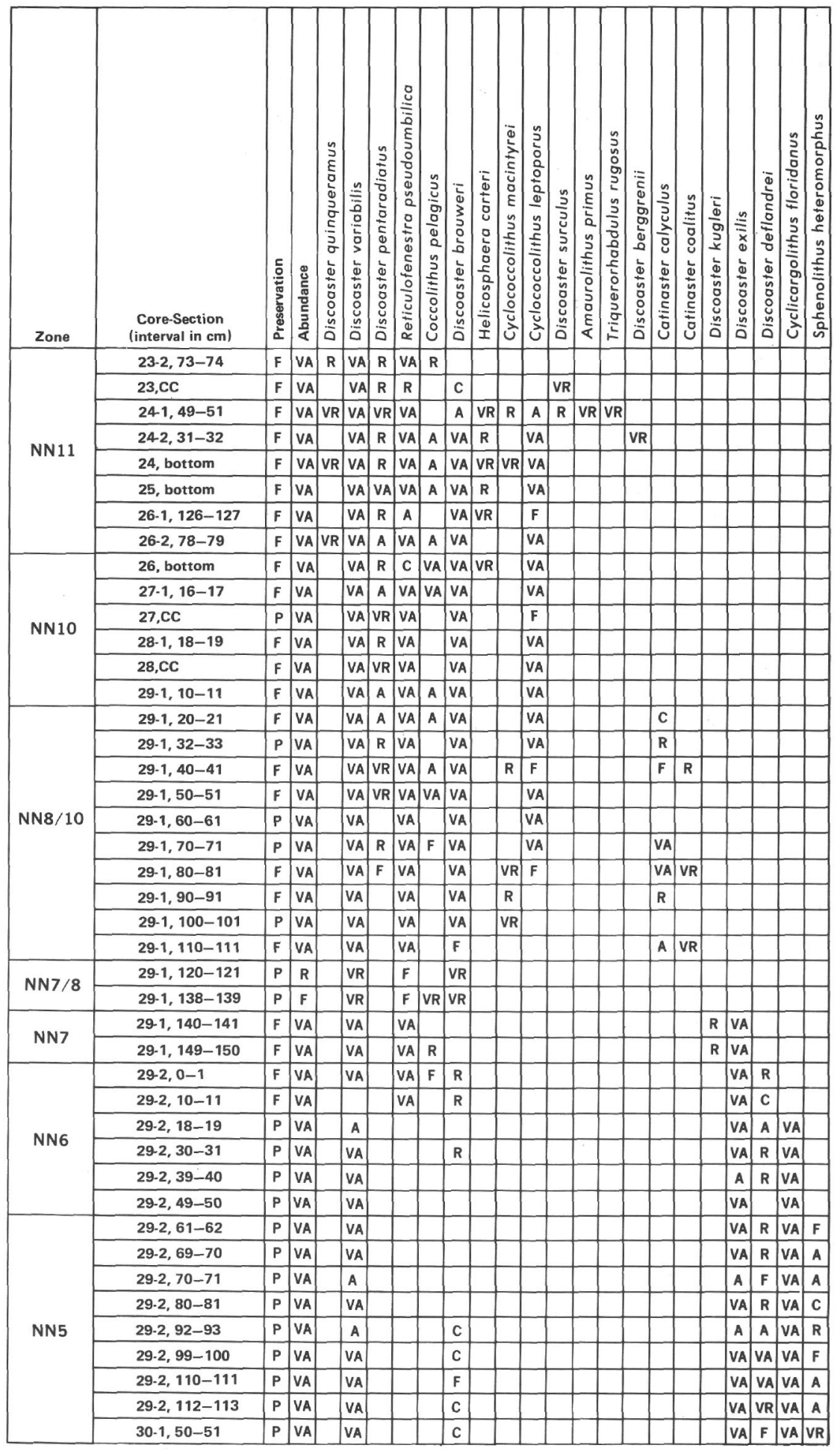


Table 4A. Distribution of calcareous nannofossils in Hole 521, Cores 1 to 14 .

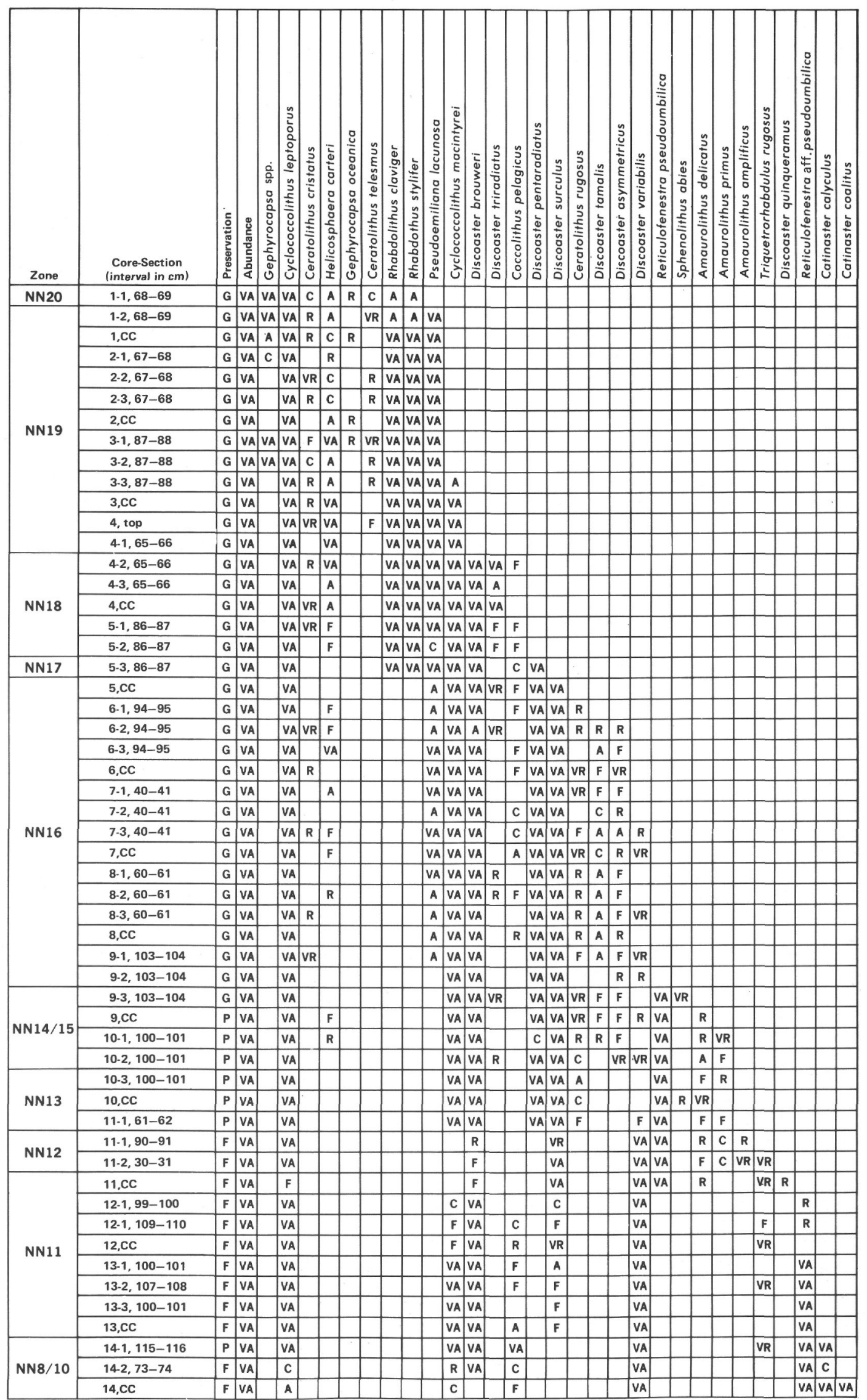


Table 4B. Distribution of calcareous nannofossils in Hole 521, Cores 16 to 21 .

\begin{tabular}{|c|c|c|c|c|c|c|c|c|c|c|c|c|c|c|}
\hline Zone & $\begin{array}{l}\text { Core-Section } \\
\text { (interval in } \mathrm{cm} \text { ) }\end{array}$ & 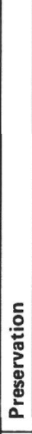 & 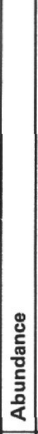 & 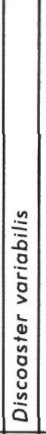 & 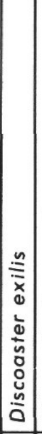 & 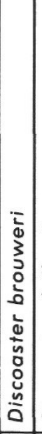 & 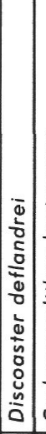 & 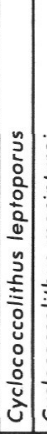 & 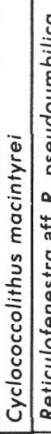 & 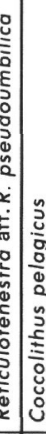 & 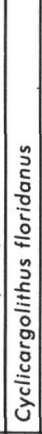 & 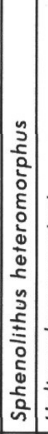 & 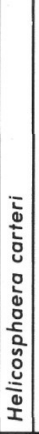 & 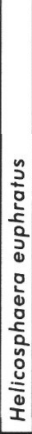 \\
\hline \multirow{3}{*}{ NN6 } & $16-1,84-85$ & $\mathbf{F}$ & VA & VA & VA & $\begin{array}{ll}\mathrm{C} \\
\end{array}$ & \begin{tabular}{|l|l}
$c$ & 1 \\
\end{tabular} & VA & \begin{tabular}{l|l}
$F$ & $V$ \\
\end{tabular} & \begin{tabular}{l|l}
$A$ & $F$ \\
\end{tabular} & & & & \\
\hline & $16-2,50-51$ & $\mathbf{F}$ & A & & A & c & & & A & & & & & \\
\hline & $16, \mathrm{CC}$ & $\mathbf{F}$ & VA & VA & A & & \begin{tabular}{|l|l|}
$\mathbf{R}$ & \\
\end{tabular} & \begin{tabular}{|l|}
$A$ \\
\end{tabular} & $F$ & $\mathbf{R}$ & VA & & & \\
\hline \multirow{15}{*}{ NN5 } & $17-1,74-75$ & $\mathbf{P}$ & VA & VA & & & & & & & VA & A & & \\
\hline & $17-2,74-75$ & $\mathbf{P}$ & VA & VA & & $\mathbf{F}$ & C & & & & VA & $\mathbf{F}$ & & \\
\hline & $17-3,74-75$ & $\mathbf{P}$ & VA & VA & & A & VA & & & & VA & A & & \\
\hline & $17, \mathrm{CC}$ & $\mathbf{P}$ & $\mathrm{VA}$ & VA & $F$ & \begin{tabular}{|l|}
$A$ \\
\end{tabular} & A & & & & VA & VA & & \\
\hline & $18-1,78-79$ & $\mathbf{P}$ & VA & VA & A & A & $\mathrm{VA}$ & & & & VA & C & & \\
\hline & $18-2,78-79$ & $\mathbf{F}$ & VA & VA & A & A & VA & & & VR & VA & A & & \\
\hline & $18-3,78-79$ & $\mathbf{P}$ & VA & VA & VA & & VA & & & & VA & A & & \\
\hline & $18, \mathrm{CC}$ & $\mathbf{P}$ & VA & VA & A & & VA & & & & VA & VA & & \\
\hline & $19-1,105-106$ & $\mathbf{P}$ & VA & VA & A & & VA & & & $\mathbf{R}$ & VA & VA & & \\
\hline & $19-2,103-104$ & $\mathbf{P}$ & VA & VA & $F$ & & VA & & & & VA & VA & & \\
\hline & $19-3,107-108$ & $\mathbf{P}$ & VA & VA & VA & & $\mathrm{VA}$ & & & $\mathbf{F}$ & VA & A & & \\
\hline & $19, \mathrm{CC}$ & $\mathbf{P}$ & VA & VA & $\mathrm{VA}$ & & VA & & & $\mathbf{R}$ & VA & A & & \\
\hline & $20-1,65-66$ & $\mathbf{P}$ & VA & VA & c & & $\mathrm{VA}$ & & & $\mathbf{R}$ & VA & VA & & \\
\hline & $20-2,65-66$ & $\mathbf{P}$ & VA & & & & VA & & & & VA & A & & \\
\hline & $20-3,65-66$ & $\mathbf{P}$ & VA & VA & & & VA & & & & VA & VA & & \\
\hline \multirow{2}{*}{ NN4 } & $20, \mathrm{CC}$ & $\mathbf{P}$ & $\mathrm{VA}$ & VA & & & $\mathrm{VA}$ & & & & VA & C & $\mathbf{F}$ & $\mathbf{R}$ \\
\hline & $21, \mathrm{CC}$ & $\mathbf{P}$ & VA & & & & A & & & & VA & $\mathbf{F}$ & $\mathbf{R}$ & \\
\hline
\end{tabular}

Table 5. Distribution of calcareous nannofossils in Hole 521A.

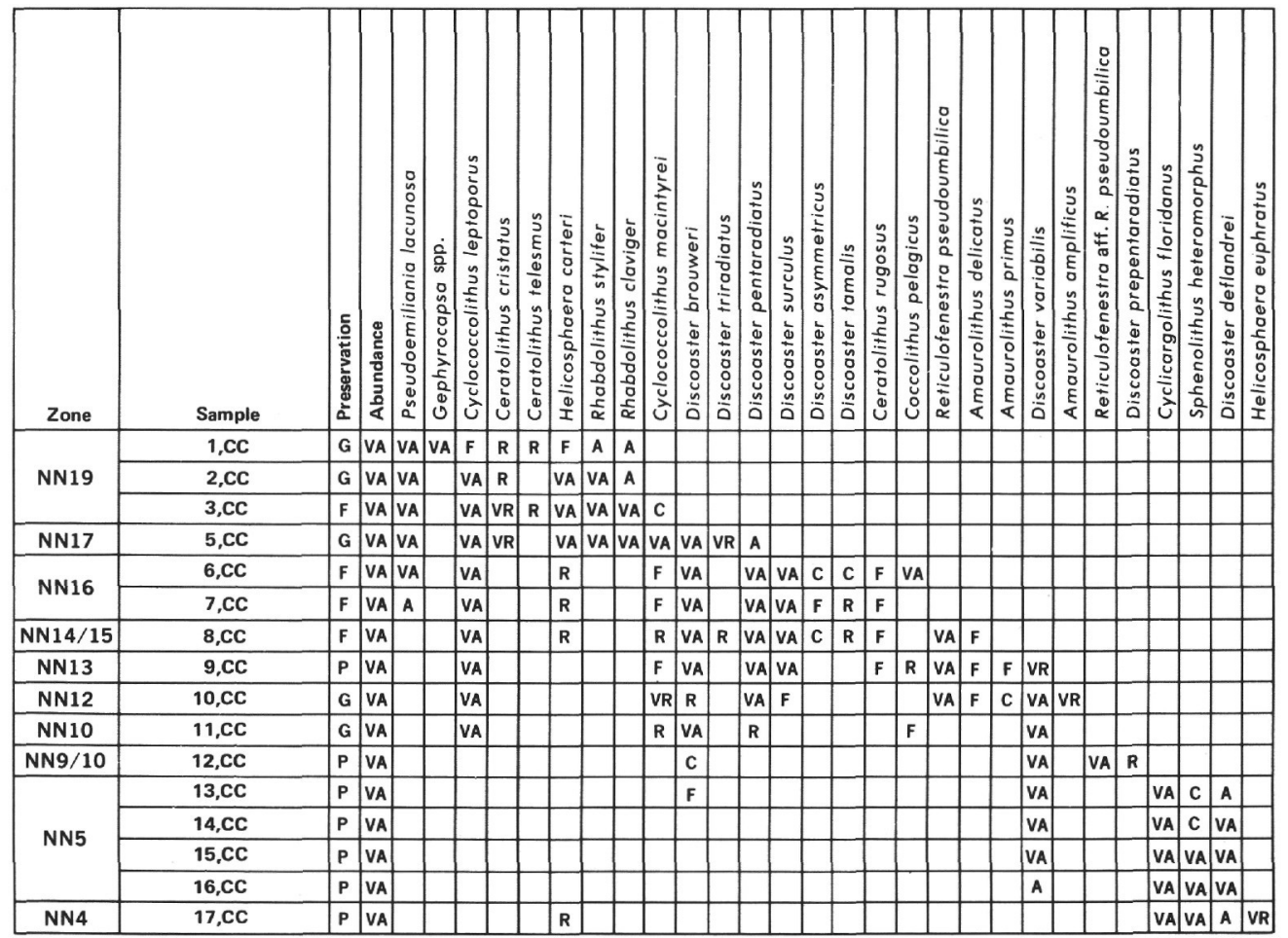


Table 6A. Distribution of calcareous nannofossils in Hole 522, Cores 1 to 15 .

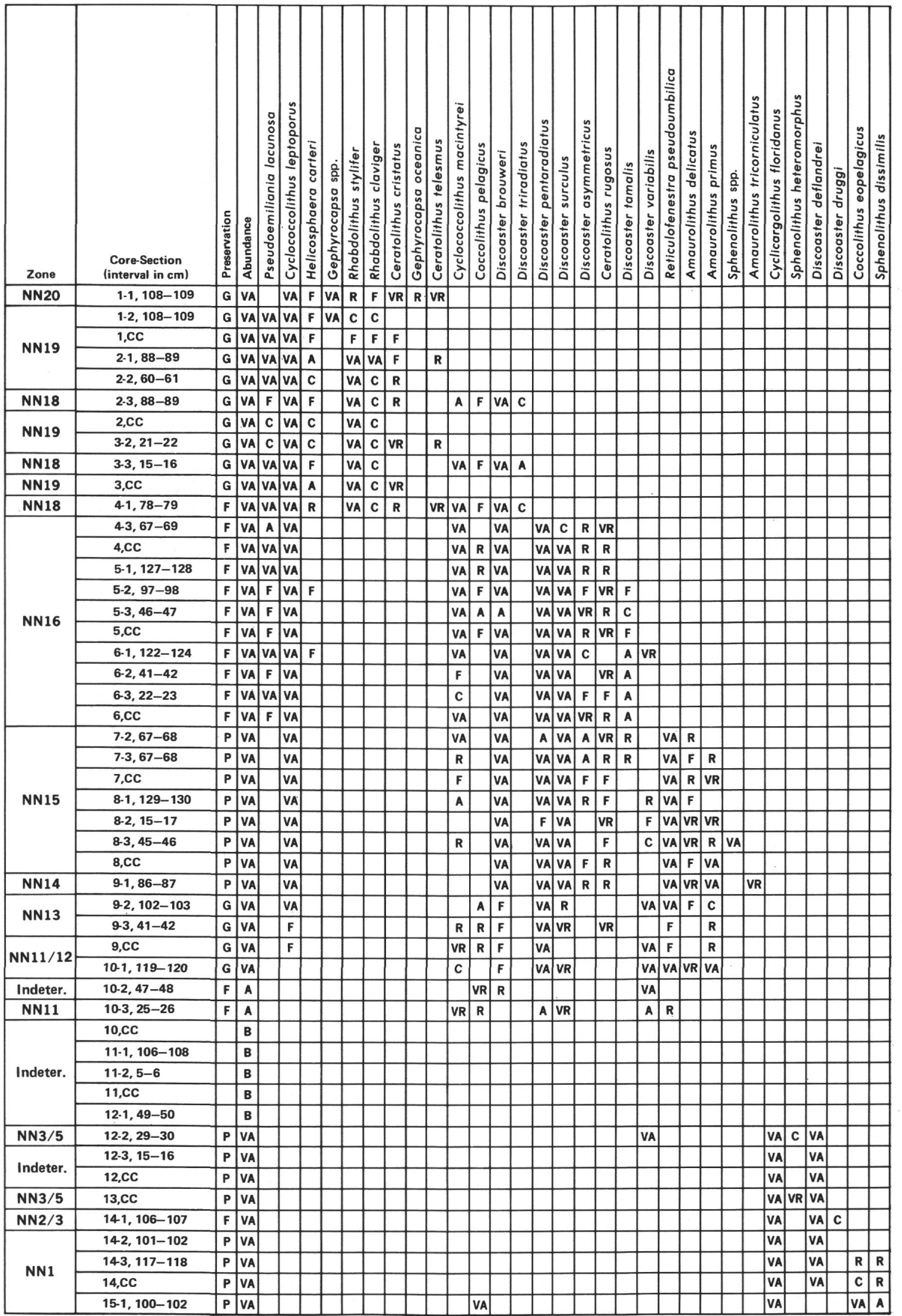


Table 6B. Distribution of calcareous nannofossils in Hole 522, Cores 15 to 29 .

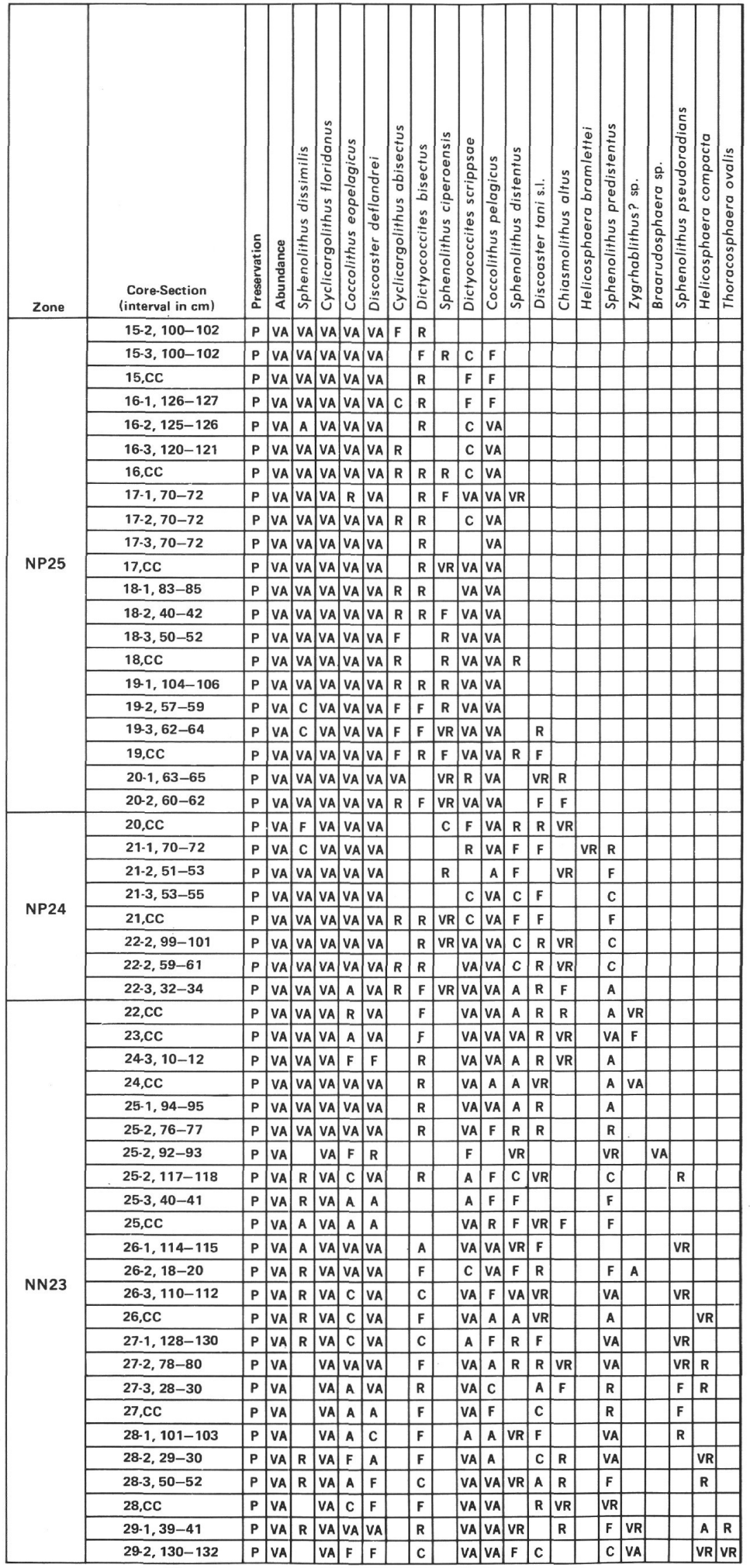


Table 6C. Distribution of calcareous nannofossils in Hole 522, Cores 29 to 39.

\begin{tabular}{|c|c|c|c|c|c|c|c|c|c|c|c|c|c|c|c|c|c|c|c|c|c|c|c|c|c|}
\hline Zone & $\begin{array}{l}\text { Core-Section } \\
\text { (interval in } \mathrm{cm} \text { ) }\end{array}$ & 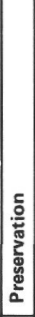 & 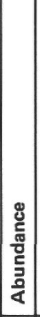 & 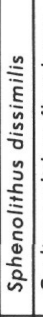 & 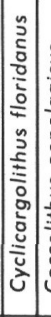 & 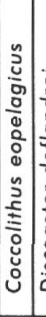 & 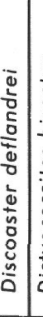 & 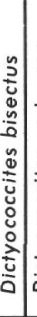 & 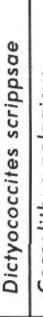 & 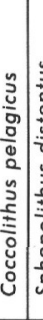 & 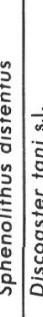 & 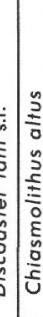 & 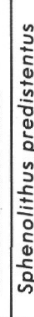 & 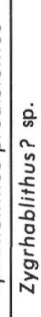 & 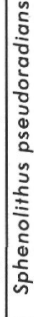 & 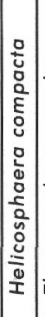 & 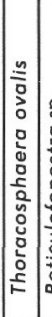 & 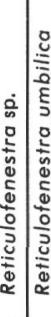 & 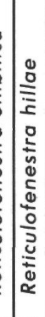 & 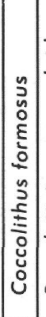 & 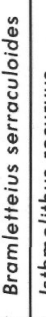 & 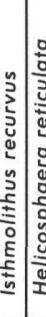 & 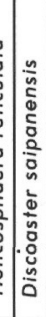 & 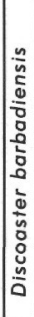 & 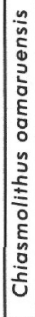 \\
\hline \multirow{7}{*}{ NP23 } & $29, \mathrm{CC}$ & $\mathbf{P}$ & VA & $\mathbf{R}$ & $\mid v_{A}$ & $\mathrm{~F}$ & $\mathrm{~F}$ & $F$ & VA $\mid \mathrm{V}$ & $\mathrm{VA}$ & v & R & $R$ & VA & & & VR & & & & & & & & \\
\hline & $30-1,20-22$ & $\mathbf{P}$ & $\mathrm{VA}$ & & \begin{tabular}{l|l} 
VA & \\
\end{tabular} & \begin{tabular}{|l|l}
$\mathbf{R}$ & \\
\end{tabular} & A & $\mathrm{F}$ & VA 1 & VA & c & c & $R$ & & $R$ & $R$ & & & & & & & & & \\
\hline & $30-2,60-62$ & $\mathbf{P}$ & VA & & VA & \begin{tabular}{l|l}
$\mathbf{R}$ \\
\end{tabular} & A & $\mathrm{F}$ & VA 1 & \begin{tabular}{ll|l} 
VA & 1 \\
\end{tabular} & $\mathbf{F}$ & $\mathrm{F}$ & VI & A VR & $F$ & VR & & A & & & & & & & \\
\hline & $30-3,100-102$ & $\mathbf{P}$ & VA & VR & \begin{tabular}{l|l} 
VA \\
\end{tabular} & \begin{tabular}{l|l}
$c$ & $v$ \\
\end{tabular} & $\mathrm{VA}$ & $\mathrm{F}$ & VA & 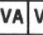 & \begin{tabular}{l|l}
$\mathrm{VR}$ & $\mathrm{V}$ \\
\end{tabular} & /A & A & VA & & & & VA & & & & & & & \\
\hline & $30, \mathrm{cc}$ & $P$ & VA & $\mathbf{R}$ & va & \begin{tabular}{l|l}
$F$ & $V$ \\
\end{tabular} & $\mathrm{VA} \mid$ & $\mathbf{F}$ & $\begin{array}{lll}A & \end{array}$ & \begin{tabular}{ll|l} 
VA & \\
\end{tabular} & v & A & $R$ & VA & & VR & & VA & & & & & & & \\
\hline & $31-1,61-63$ & $P$ & VA & $\mathbf{F}$ & VA & \begin{tabular}{l|l}
$F$ & $V$ \\
\end{tabular} & VA & c| & VATV & VA & vi & A & vi & & VR & $\mathbf{R}$ & & & & & & & & & \\
\hline & $31-2,49-51$ & $P$ & VA & A & \begin{tabular}{|l|l}
$\mathrm{VA}$ & 1 \\
\end{tabular} & $\begin{array}{lll}A & V \\
\end{array}$ & $\mathrm{VA}$ & c & VA $\mathrm{V}$ & $\mathrm{VA}$ & v & A & c & $F$ & $R$ & VR & & & & & & & & & \\
\hline \multirow{5}{*}{ NP22 } & $31-3,49-51$ & $\mathbf{P}$ & VA & $\mathrm{R}$ & VA & $F$ & $\mathrm{va}$ & c & VA & VA & vi & A & $\mathrm{V}$ & A VA & $\mathrm{c}$ & $\mathbf{F}$ & & $\mathrm{F}$ & & & & & & & \\
\hline & $31, \mathrm{cc}$ & $P$ & VA & $\mathrm{R}$ & VA & $\mathrm{F}$ & $\mathrm{VA}$ ] & $\mathbf{F}$ & VA 1 & VA & v & $\begin{array}{lll}A & F \\
\end{array}$ & $\mathrm{R}$ & VA & $R$ & & & $\mathrm{R}$ & & & & & & & \\
\hline & $32-1,69-71$ & $P$ & VA & & va & \begin{tabular}{l|l}
$F$ & $V$ \\
\end{tabular} & $\mathrm{VA}$ & c & VA & VA & $\mathrm{F}$ & $\begin{array}{ll}F & R \\
\end{array}$ & vi & \begin{tabular}{l|l} 
VA \\
\end{tabular} & $F$ & & & $\mathrm{R}$ & R & & & & & & \\
\hline & $32-2,43-45$ & $P$ & $\mathrm{VA}$ & $\mathbf{R}$ & VA & \begin{tabular}{l|l} 
VR & I
\end{tabular} & VA] & A & VA $\mid \mathrm{V}$ & $V_{A}$ & $\mathrm{~F}$ & \begin{tabular}{l|l}
$F$ & $R$ \\
\end{tabular} & $\mathbf{R}$ & VA & & VR & & $\mathbf{R}$ & $\mathbf{R}$ & & & & & & \\
\hline & $32-3,59-61$ & $P$ & VA & $F$ & va & \begin{tabular}{|l|l}
$F$ \\
\end{tabular} & A & $F$ & VA & $V A$ & $A$ & \begin{tabular}{l|l}
$A$ & $V F$ \\
\end{tabular} & $\mathrm{~V}$ & $\begin{array}{ll}\text { RA } \\
\text {. }\end{array}$ & $R$ & VR & & $\mathrm{R}$ & $\begin{array}{ll}\mathrm{R} \\
\end{array}$ & & & & & & \\
\hline \multirow{13}{*}{ NP21 } & $32, \mathrm{CC}$ & $P$ & VA & & \begin{tabular}{|l|l|l|} 
VA & \\
\end{tabular} & \begin{tabular}{l|l} 
c & \\
\end{tabular} & c & $F$ & $\begin{array}{lll}V A & \end{array}$ & VA & c & \begin{tabular}{l|l}
$C$ & $R$ \\
\end{tabular} & F & VA & c & VR & & $\mathbf{R}$ & R & VR & & & & & \\
\hline & $33-1,60-62$ & $\mathbf{P}$ & $\mathrm{VA}$ & $\mathbf{R}$ & VA & \begin{tabular}{|l|l}
$\mathbf{R}$ & \\
\end{tabular} & A & $\mathbf{R}$ & VA & $V_{A}$ & $F$ & \begin{tabular}{l|l} 
\\
\end{tabular} & & VA & & & & VF & \begin{tabular}{|l|l}
$\mathbf{R}$ & $\mathrm{R}$ \\
\end{tabular} & A & & & & & \\
\hline & $33-2,44-46$ & $\mathbf{P}$ & $\mathrm{VA}$ & \begin{tabular}{|l|}
$R$ \\
\end{tabular} & VA & \begin{tabular}{l|l}
$R$ & \\
\end{tabular} & c| & $\mathbf{R}$ & VA & $\mathrm{VA}$ & $F$ & $F$ & $\mathrm{~F}$ & & VR & \begin{tabular}{|l|}
$\mathbf{R}$ \\
\end{tabular} & VR & $F$ & F & $\mathbf{F}$ & VA & & & & \\
\hline & $33, \mathrm{cc}$ & $P$ & $\mathrm{VA}$ & $R$ & va & \begin{tabular}{l|l}
$F$ \\
\end{tabular} & A & $\mathbf{R}$ & VA & VA & $\mathrm{F}$ & \begin{tabular}{l|l}
$F$ & $V F$
\end{tabular} & & VA & & VR & VR & $F$ & $\begin{array}{l}\text { C } \\
\text { c }\end{array}$ & va & $\mathbf{R}$ & & & & \\
\hline & $34-1,83-84$ & $P$ & $\mathrm{VA}$ & & VA & \begin{tabular}{l|l}
$c$ \\
\end{tabular} & $\mathrm{~F}$ & $\mathbf{R}$ & VA & $\mathrm{VA}$ & $\mathrm{F}$ & $\mathrm{F}$ & & VA & VR & VR & & $\mathrm{R}$ & c & c & \begin{tabular}{l|l}
$A$ & $V$ \\
\end{tabular} & VR & & & \\
\hline & $34-2,53-55$ & $P_{1}$ & VA & c & VA & A & A & $F$ & VA $\mathrm{V}$ & VA & $\mathrm{F}$ & $\mathrm{F}$ & & VA & VR & & & $\mathbf{R}$ & $F$ & va & A & vi & & & \\
\hline & $34-3,49-51$ & $\mathbf{P}$ & VA & $\mathbf{R}$ & \begin{tabular}{ll|l} 
VA & I \\
\end{tabular} & VR & A & $\mathbf{R}$ & VA $\mathrm{V}$ & VA & $\mathrm{F}$ & $\mathrm{F}$ & R & VA & & VR & & $\mathrm{F}$ & C & $\begin{array}{ll} & \\
\end{array}$ & VA $V$ & VR & & & \\
\hline & $34, \mathrm{CC}$ & $\mathbf{P}$ & $\mathrm{VA}$ & $\mathrm{F}$ & $\mathrm{VA}$ & \begin{tabular}{l|l}
$\mathbf{F}$ \\
\end{tabular} & \begin{tabular}{l|l} 
c \\
\end{tabular} & $\mathbf{F}$ & VA $V$ & VA & $R$ & $R$ & VA & VA & VR & VR & & $\mathrm{F}$ & C & A & \begin{tabular}{l|l}
$V A$ & $F$ \\
\end{tabular} & $\mathbf{R}$ & & & \\
\hline & $35-2,50-52$ & $\mathbf{P}$ & VA & & VA & \begin{tabular}{l|l} 
\\
\end{tabular} & $\mathbf{F}$ & $\mathbf{R}$ & VA & VA & $\mathrm{F}$ & $\mathbf{R}$ & v & & $\mathbf{R}$ & & & $\mathbf{F}$ & c & A & \begin{tabular}{l|l} 
VA & I \\
\end{tabular} & $\mathbf{R}$ & & & \\
\hline & $35, \mathrm{cc}$ & $P$ & $V_{A}$ & \begin{tabular}{|l|l}
$R$ \\
\end{tabular} & va & $F$ & va & $\mathbf{F}$ & \begin{tabular}{l|l|l} 
VA & \\
\end{tabular} & VA & $A$ & A & $\mathrm{R}$ & & $F$ & VR & & $F$ & c & A & VA & & & & \\
\hline & $36-1,64-66$ & $\mathbf{P}$ & VA & $\mathrm{VA}$ & $\mathrm{VA}$ & \begin{tabular}{l|l}
$\mathbf{R}$ \\
\end{tabular} & A & $\mathbf{F}$ & VA $V$ & $\mathrm{VA}$ & $\mathrm{F}$ & $\mathrm{F}$ & & $\mathbf{F}$ & $R$ & & & $\mathrm{c}$ & VA & c & \begin{tabular}{l|l}
$F$ & 1 \\
\end{tabular} & $\mathbf{F}$ & & & \\
\hline & $36-2,49-51$ & $P$ & $\mathrm{VA}$ & A & $\mathrm{VA}$ & \begin{tabular}{l|l}
$\mathbf{R}$ \\
\end{tabular} & A & $\mathbf{R}$ & VA & $\mathrm{VA}$ & $\mathrm{F}$ & & & VA & VR & & & $\mathrm{c}$ & VA & $R$ & \begin{tabular}{l|l}
$\mathbf{F}$ & 1 \\
\end{tabular} & $\mathbf{F}$ & & & \\
\hline & $36-3,30-31$ & $\mathbf{P}$ & VA & $\mathrm{F}$ & va & $\mathbf{R}$ & VA] & c & VA & VA] & A & & & & $\mathbf{F}$ & VR & VR & A & VA & $\mathbf{F}$ & VA $\mid V$ & VR & & & \\
\hline \multirow{9}{*}{ NP20 } & $36, \mathrm{cc}$ & $\mathbf{P}$ & VA & VA & VA & $\mathbf{R}$ & VA & $\mathbf{F}$ & VA 1 & VA & v & A & & VA & c & & $\mathbf{R}$ & $\mathbf{R}$ & A & $\mathrm{F}$ & VA $\mid \mathrm{V}$ & VR & R & & \\
\hline & $37.1,100-102$ & $\mathbf{P}$ & $\mathrm{VA}$ & A & vA & \begin{tabular}{l|l}
$\mathbf{F}$ & \\
\end{tabular} & $\mathrm{vA}$ & $\mathbf{F}$ & VA & $\mathrm{VA}$ & $\mathrm{v}$ & AA & & VA & $R$ & & & A & A & $\mathbf{R}$ & VA $V$ & VR & & & \\
\hline & $37-2,119-121$ & $P$ & $\mathrm{VA}$ & VA & VA & VR & va & $\mathbf{R}$ & VA & VA & v & IA & & VA & $R$ & & & v & $\begin{array}{ll}\text { A VA } \\
\end{array}$ & $F$ & VA & & & VR & \\
\hline & $29, \mathrm{CC}$ & $P$ & $\mathrm{VA}$ & VA & VA & \begin{tabular}{l|l}
$R$ \\
\end{tabular} & VA & $\mathbf{F}$ & VA & $\mathrm{VA}$ & v & IA & & VA & $R$ & & & A & A & $F$ & $\begin{array}{lll}\text { VA } & \text { I } \\
\end{array}$ & $\mathbf{F}$ & VR & $R$ & \\
\hline & $37, \mathrm{CC}$ & $P$ & VA & VA & VA & & $\overrightarrow{v e r}$ & $\mathbf{F}$ & VA & $\mathrm{VA}$ & v & IA & & VA & $F$ & & & vi & \begin{tabular}{|l|l|}
$A$ & $F$ \\
\end{tabular} & $F$ & \begin{tabular}{l|l} 
VA & I \\
\end{tabular} & $\mathbf{R}$ & VR & & \\
\hline & $38-1,120-122$ & $\mathbf{P}$ & VA & VA & VA & \begin{tabular}{l|l}
$\mathbf{R}$ \\
\end{tabular} & VA & $F$ & VA & VA & v & IA & & VA & $F$ & VR & & v & $\mathrm{A}$ VA & c & VA & $\mathbf{R}$ & $\mathbf{R}$ & VR & \\
\hline & $38-2,121-122$ & $\mathbf{P}$ & VA & $F$ & VA & A & VA & $\mathbf{R}$ & VA & $\overrightarrow{V A}$ & v & IA & & A & A & & & vi & $\begin{array}{l}\mathrm{A} \\
\mathrm{A}\end{array}$ & c & VA & & C & VA & $F$ \\
\hline & $38, \mathrm{CC}$ & $P$ & $\mathrm{VA}$ & VA & VA & & vA & $\mathbf{R}$ & VA & VA & v & IA & & VA & $R$ & & & v & A $A$ & $\mathbf{R}$ & \begin{tabular}{l|l} 
VA & I \\
\end{tabular} & $\mathbf{R}$ & VA & $F$ & $F$ \\
\hline & $39, \mathrm{cc}$ & $\mathrm{P}$ & VA & VA & $\mathrm{vA}$ & $\mathbf{F}$ & \begin{tabular}{ll|}
$V_{A}$ & \\
\end{tabular} & $\mathbf{R}$ & VA & $\mathrm{VA}$ & v & $|A|$ & & VA & $R$ & $\left|v_{i a}\right|$ & & $A$ & a & $F$ & VA 1 & $\mathbf{R}$ & A & & $\mathrm{R}$ \\
\hline
\end{tabular}


Table 7. Distribution of calcareous nannofossils in Hole 522A.

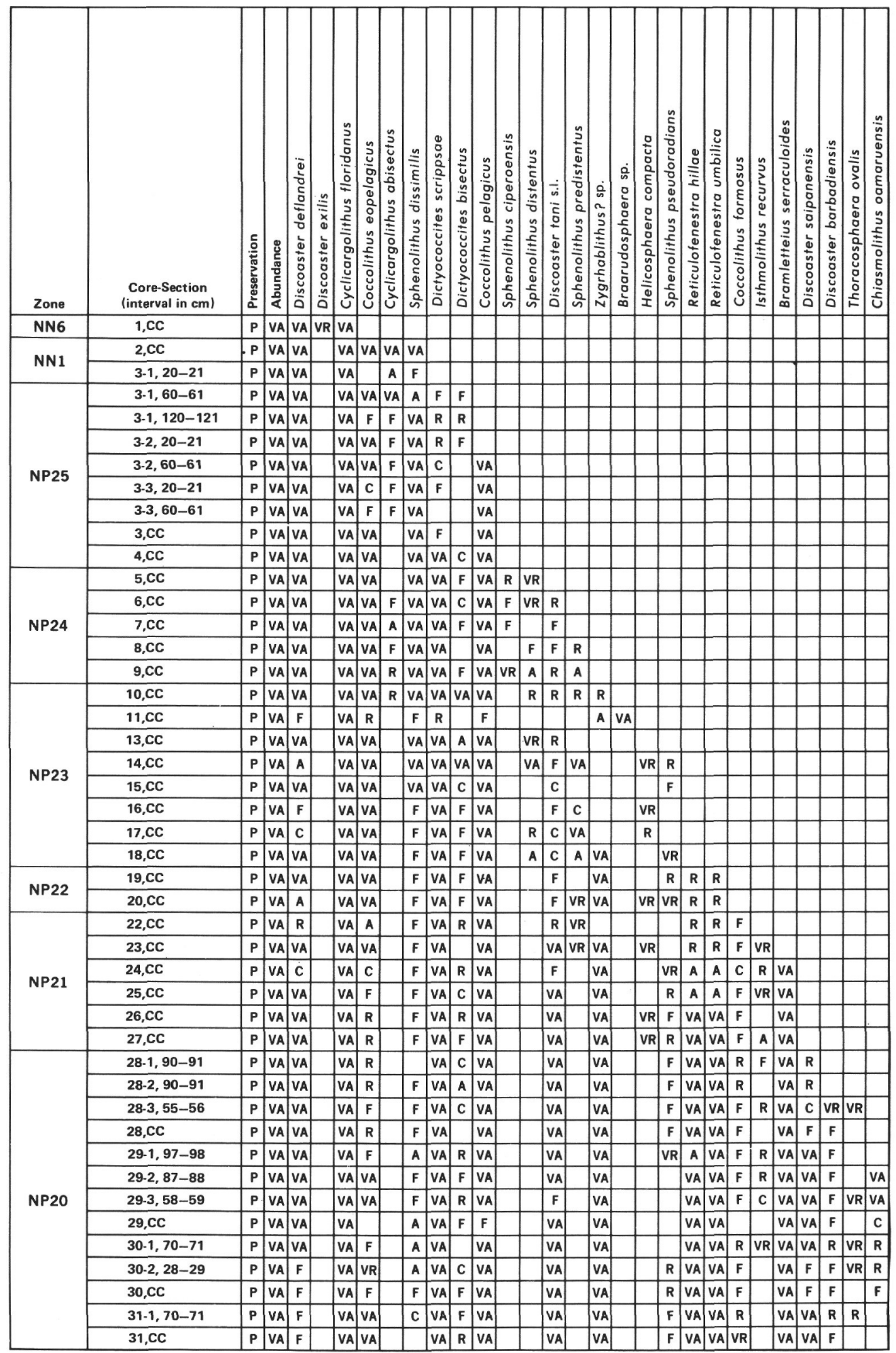


Table 8. Distribution of calcareous nannofossils in Hole 522B.

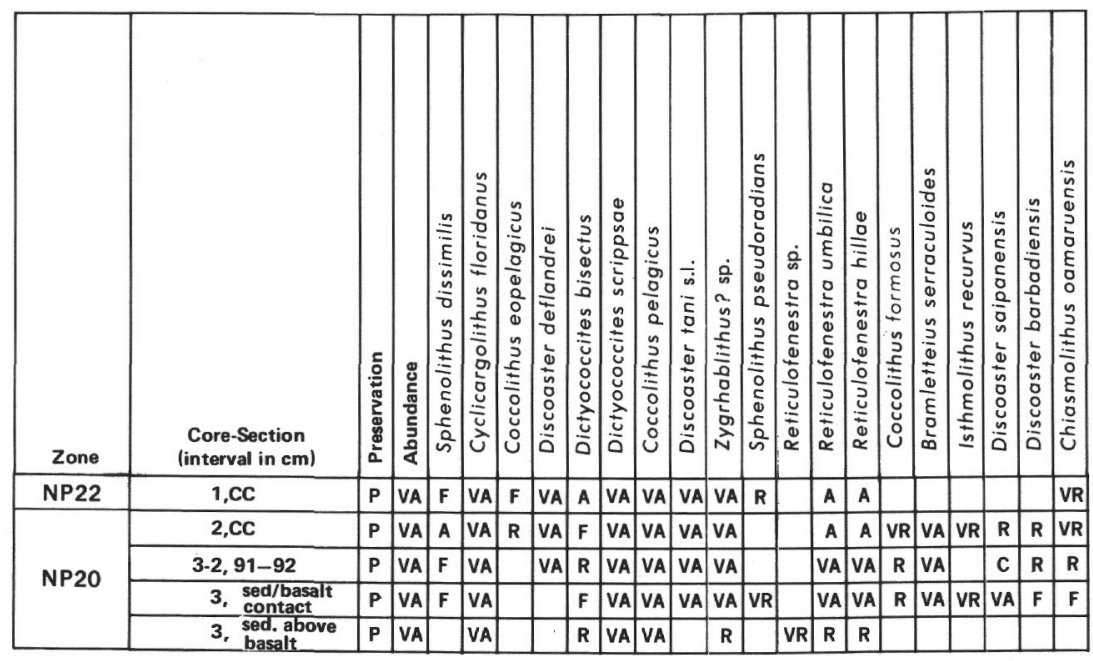

Table 9A. Distribution of calcareous nannofossils in Hole 523, Cores 1 to 7.

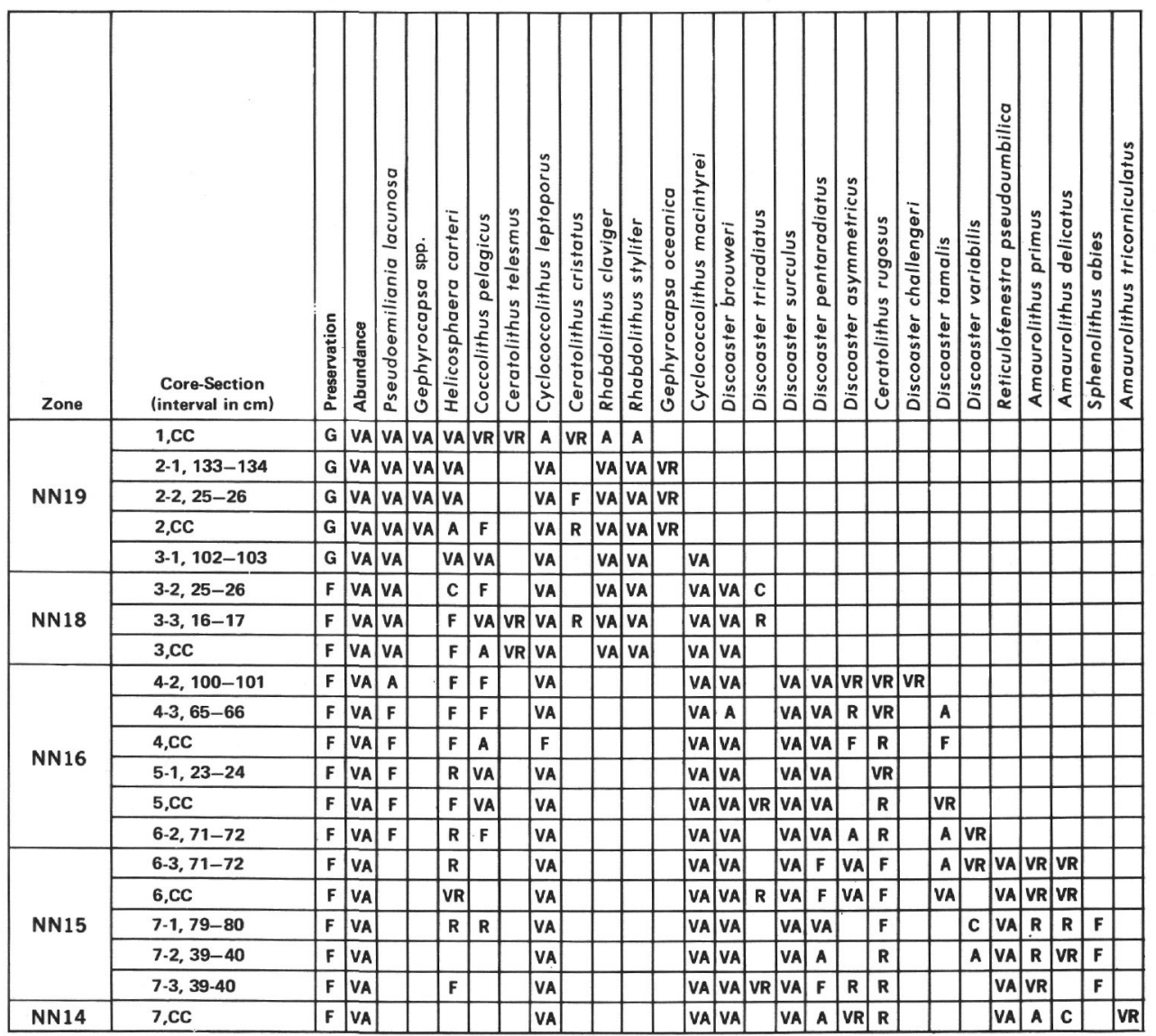


Table 9B. Distribution of calcareous nannofossils in Hole 523, Cores 8 to 24 .

\begin{tabular}{|c|c|c|c|c|c|c|c|c|c|c|c|c|c|c|c|c|c|c|c|c|c|c|c|c|}
\hline Zone & $\begin{array}{c}\text { Core-Section } \\
\text { (interval in cm) }\end{array}$ & 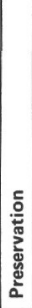 & 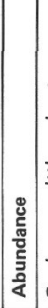 & 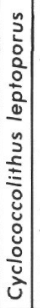 & 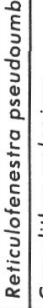 & 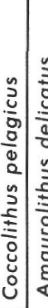 & 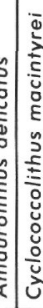 & 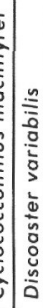 & 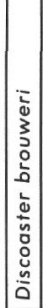 & 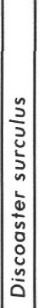 & 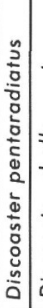 & 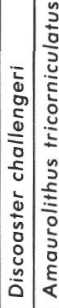 & 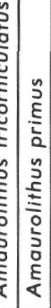 & 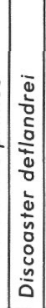 & 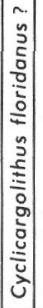 & 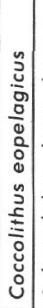 & 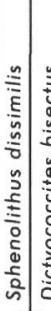 & 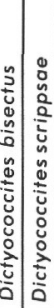 & 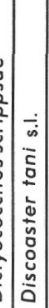 & 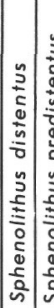 & 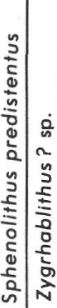 & 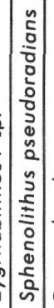 & & 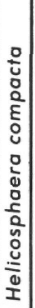 \\
\hline \multirow{8}{*}{ NN11 12} & $8-1,51-52$ & $\mathrm{~F}$ & VA & c & VA & \begin{tabular}{l|l}
$F$ & $F$ \\
\end{tabular} & F & VR & VA & $A$ & \begin{tabular}{l|l}
$A$ & 1 \\
\end{tabular} & \begin{tabular}{l|l|l|} 
VA & VF \\
\end{tabular} & & & & & & & & & & & & \\
\hline & $8-2,51-52$ & $F$ & $\mathrm{VA}$ & VR & \begin{tabular}{l|l} 
& \\
\end{tabular} & vF & & & & $R$ & $R$ & A & & & & & & & & & & & & \\
\hline & $8-3,51-52$ & $\mathbf{P}$ & \begin{tabular}{ll|l} 
VA & \\
\end{tabular} & $\mathbf{R}$ & A & D F & $R$ & & $R$ & $R$ & \begin{tabular}{l|l}
$\mathbf{R}$ & $\mathrm{I}$ \\
$\mathrm{H}$
\end{tabular} & VA & & & & & & & & & & & & \\
\hline & $8, \mathrm{CC}$ & $\mathbf{P}$ & \begin{tabular}{|l|l|} 
VA \\
\end{tabular} & $\mathbf{R}$ & VA $V$ & \begin{tabular}{l|l} 
VR & $R$ \\
\end{tabular} & & & & VR & \begin{tabular}{l|l}
$R$ & I \\
\end{tabular} & $\mathrm{VA}$ & VR & & & & & & & & & & & \\
\hline & $10-1,124-125$ & $P$ & \begin{tabular}{|l|l|} 
\\
\end{tabular} & & \begin{tabular}{l|l} 
c & \\
\end{tabular} & $\mathrm{VF}$ & \begin{tabular}{|l|l}
$R$ & $R$ \\
\end{tabular} & & VR & VR & & VR & $\mathbf{R}$ & & & & & & & & & & & \\
\hline & $10-2,58-59$ & & B & & & & & & & & & & & & & & & & & & & & & \\
\hline & $10-3,50-51$ & $\mathbf{P}$ & VA & VR & VA & $R$ & & VR & VR & VR & $R$ & & & & & & & & & & & & & \\
\hline & $10, \mathrm{CC}$ & $P$ & VA & A & VA & $\mathrm{R}$ & $F$ & & & $F$ & $\mathrm{~F} / \mathrm{Y}$ & VR & & & & & & & & & & & & \\
\hline NN11 & $11-1,145-146$ & $P$ & \begin{tabular}{|l|l|}
$R$ \\
\end{tabular} & $\mathbf{R}$ & & VR & & VR & $\mathbf{F}$ & $R$ & \begin{tabular}{l|l} 
VR \\
\end{tabular} & & & & & & & & & & & & & \\
\hline NN4/6 & $11-2,60-61$ & $\mathbf{P}$ & VA & & & & & & $\mathbf{R}$ & & & & & VA & VA & & & & & & & & & \\
\hline \multirow{2}{*}{ NN1 } & $11-3,5-6$ & $P$ & VA & & & & & & & & & & & VA & VA & c & $R$ & & & & & & & \\
\hline & $11, \mathrm{CC}$ & $F$ & VA & & & & & & & & & & & VA & $\mathrm{VA}$ & A & $\mathbf{R}$ & & & & & & & \\
\hline \multirow{12}{*}{ NP25 } & $12-1,120-121$ & $F$ & VA & & & & & & & & & & & VA & VA & A 1 & \begin{tabular}{l|l} 
VA & $R$ \\
\end{tabular} & \begin{tabular}{l|l|}
$R$ & $F$ \\
\end{tabular} & & & & & & \\
\hline & $12-2,65-66$ & $F$ & VA & & & & & & & & & & & VA & VA & VA & \begin{tabular}{|l|l|}
$F$ & $F$ \\
\end{tabular} & \begin{tabular}{|l|l|}
$F$ & $F$ \\
\end{tabular} & & & & & & \\
\hline & $12-3,16-17$ & $F$ & VA & & & 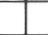 & & & & & & & & VA & $\mathrm{VA}$ & A & \begin{tabular}{|l|l|}
$F$ & $F$ \\
\end{tabular} & \begin{tabular}{|l|l|}
$F$ & VA \\
\end{tabular} & & & & & & \\
\hline & $12, \mathrm{CC}$ & $F$ & va & & & A & & & & & & & & $\mathrm{VA}$ & $\mathrm{VA}$ & A & \begin{tabular}{|l|l|}
$F$ & $F$ \\
\end{tabular} & \begin{tabular}{|l|l}
$F$ & VA \\
\end{tabular} & & & & & & \\
\hline & $13-1,60-61$ & $F$ & va & & & $\mathbf{F}$ & & & & & & & & VA & vA & $F$ & \begin{tabular}{|l|l|}
$F$ & $F$ \\
\end{tabular} & \begin{tabular}{|l|l|}
$F$ & VA \\
\end{tabular} & & & & & & \\
\hline & $13-2,60-61$ & $F$ & va & & & A & & & & & & & & $\mathrm{VA}$ & VA & A & \begin{tabular}{l|l}
$\mathbf{F}$ & \\
\end{tabular} & VA & & & & & & \\
\hline & $13-3,60-61$ & $F$ & va & & & & & & & & & & & $\mathrm{VA}$ & VA & $F$ & $\mathrm{~F}$ & \begin{tabular}{|l|l|}
$F$ & VA \\
\end{tabular} & & & & & & \\
\hline & $13, \mathrm{CC}$ & $\mathrm{F}$ & VA & & & & & & & & & & & VA & va & $\mathbf{F}$ & $\mathbf{R}$ & A & & & & & & \\
\hline & $14-1,105-106$ & $\mathrm{~F}$ & VA & & & A & & & & & & & & VA & va & c & & \begin{tabular}{ll|l|}
$A$ & $V A$ \\
\end{tabular} & $R$ & & & & & \\
\hline & $14-2,86-87$ & $\mathbf{P}$ & VA & & & $\mathbf{F}$ & & & & & & & & $\mathrm{VA}$ & VA & $\mathbf{F}$ & & VA & $R$ & & & & & \\
\hline & $14-3,16-17$ & $\mathbf{P}$ & va & & & va & & & & & & & & $\mathrm{V}_{\mathrm{A}}$ & VA & A & & VA & & & & & & \\
\hline & $14, \mathrm{CC}$ & $\mathrm{P}$ & VA & & & $\mathrm{va}$ & & & & & & & & VA & $\mathrm{VA}$ & A & & VA & & & & & & \\
\hline \multirow{4}{*}{ NP24 } & $15, \mathrm{CC}$ & $\mathbf{F}$ & VA & & & VA & & & & & & & & VA & VA & VA & \begin{tabular}{l|l} 
VA & $R$ \\
\end{tabular} & \begin{tabular}{l|l|}
$R$ & VA \\
\end{tabular} & & \begin{tabular}{l|l} 
VR & F \\
\end{tabular} & $\mathbf{F}$ & & & \\
\hline & $16-1,59-60$ & $\mathbf{P}$ & VA & & & c & & & & & & & & $R$ & vA & $\mathbf{F}$ & & $\begin{array}{l}\mathrm{VA} \\
\mathrm{VA}\end{array}$ & & & & & & \\
\hline & $16-2,48-49$ & $\mathbf{P}$ & VA & & & $\mathrm{VA}$ & & & & & & & & $F$ & va & $\mathbf{F}$ & & \begin{tabular}{l|l|}
$R$ & $V A A$ \\
\end{tabular} & $F$ & & $\mathrm{VA}$ & & & \\
\hline & $16, \mathrm{CC}$ & $\mathrm{F}$ & VA & & & $\mathrm{VA}$ & & & & & & & & $R$ & VA & VAa & & \begin{tabular}{l|l|}
$F$ & $V A$ \\
\end{tabular} & $F$ & & VA & & & \\
\hline \multirow{23}{*}{ NP23 } & $17, \mathrm{CC}$ & $\mathrm{F}$ & VA & & & VA & & & & & & & & VA & VA & \begin{tabular}{l|l}
$\mathbf{F}$ \\
\end{tabular} & R & \begin{tabular}{|l|l|}
$R$ & $V A$ \\
\end{tabular} & $F$ & & \begin{tabular}{l|l|}
$C$ & $A$ \\
\end{tabular} & $R$ & & \\
\hline & $18, \mathrm{CC}$ & $\mathbf{F}$ & $v A$ & & & VA & & & & & & & & VA & VA & VA & \begin{tabular}{l|l}
$F$ & $F$ \\
\end{tabular} & \begin{tabular}{|l|l}
$F$ & $V A$ \\
\end{tabular} & & & \begin{tabular}{l|l|}
$\mathrm{VR}$ & \\
\end{tabular} & & & \\
\hline & $19-1,52-53$ & $F$ & VA & & & $\mathbf{R}$ & & & & & & & & & c| & \begin{tabular}{l|l}
$\mathrm{VR}$ \\
\end{tabular} & & VR & & & & & $\begin{array}{ll}\text { VA } \\
\end{array}$ & \\
\hline & $19-1,96-97$ & $F$ & vA & & & VA & & & & & & & & VA & VA & \begin{tabular}{l|l}
$R$ \\
\end{tabular} & \begin{tabular}{l|l}
$F$ & $R$ \\
\end{tabular} & \begin{tabular}{|l|l|}
$R$ & $V A$ \\
\end{tabular} & & VR & & & & \\
\hline & $19-2,64-65$ & $\mathbf{F}$ & VA & & & va & & & & & & & & VA & VA & \begin{tabular}{l|l}
$\mathbf{A}$ & \\
\end{tabular} & c & \begin{tabular}{c|c|}
$c$ & $V A$ \\
\end{tabular} & & 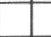 & & & & \\
\hline & $19-3,16-17$ & $\mathbf{F}$ & VA & & & $\mathrm{VA}$ & & & & & & & & VA & VA & VA & c & \begin{tabular}{l|l}
$c$ & $V A$ \\
\end{tabular} & & \begin{tabular}{l|l}
$R$ & $R$ \\
\end{tabular} & $\mathbf{R}$ & & & \\
\hline & $19, \mathrm{CC}$ & $\mathbf{F}$ & VA & & & $\mathrm{VA}$ & & & & & & & & $\mathrm{A}$ & VA & c & A & $\begin{array}{ll}A & V A \\
\end{array}$ & & & $\mathrm{VR}$ & & & \\
\hline & $20-1,98-99$ & $F$ & VA & & & VA & & & & & & & & VA & VA & $\mathrm{c}$ & 5 & \begin{tabular}{|l|l|}
$R$ & $V A$ \\
\end{tabular} & $\mathbf{R}$ & & $\mathbf{R}$ & & & \\
\hline & $20-2,25-26$ & $\mathbf{F}$ & VA & & & $\mathrm{VA}$ & & & & & & & & $R$ & VA & $F$ & $\mathrm{~F}$ & \begin{tabular}{|l|l|} 
& $V A$ \\
\end{tabular} & VR & & & $\mathbf{R}$ & & \\
\hline & $20-2,112-113$ & $F$ & VA & & & $R$ & & & & & & & & $F$ & VA & $R$ & c & \begin{tabular}{c|c|}
$c$ & $V A$ \\
\end{tabular} & $F$ & vi & R & & & \\
\hline & $20, \mathrm{CC}$ & $F$ & VA & & & A & & & & & & & & c & VA & $R$ & $F$ & 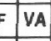 & $F$ & \begin{tabular}{l|l}
$V_{R}$ & $A$ \\
\end{tabular} & A & & & \\
\hline & $21-1,125-126$ & $F$ & VA & & & c & & & & & & & & A & VA & $\mathbf{F}$ & F & \begin{tabular}{|l|l|} 
& $V A$ \\
\end{tabular} & $\mathbf{F}$ & 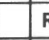 & $R$ & & & \\
\hline & $21-2,125-126$ & $\mathbf{F}$ & VA & & & VA & & & & & & & & VA & VA & \begin{tabular}{l|l} 
c & \\
\end{tabular} & \begin{tabular}{l|l}
$F$ & $v$ \\
\end{tabular} & A VA & $F$ & $\mathrm{~F}$ & $F$ & & & \\
\hline & $21 \cdot 3,66-67$ & $F$ & VA & & & VA & & & & & & & & A & VA & c & F & \begin{tabular}{|l|l|}
8 & VA \\
\end{tabular} & A & F & $R$ & & & \\
\hline & $21, \mathrm{CC}$ & $F$ & VA & & & VA & & & & & & & & $\mathrm{F}$ & VA & \begin{tabular}{l|l}
$R$ \\
\end{tabular} & 1 & $\begin{array}{ll}A & V A \\
\end{array}$ & $\mathbf{R}$ & $\mathrm{F}$ & R & & & \\
\hline & $22-1,87-88$ & $F$ & VA & & & VA & & & & & & & & $\mathbf{F}$ & VA & VR & \begin{tabular}{l|l}
$R$ & $F$ \\
\end{tabular} & \begin{tabular}{|l|l|}
$f$ & $V A$ \\
\end{tabular} & $\mathbf{R}$ & & & & & \\
\hline & $22-2,87-88$ & $\mathbf{F}$ & VA & & & $\mid \mathrm{VA}$ & & & & & & & & $F$ & VA & \begin{tabular}{l|l}
$R$ \\
\end{tabular} & A & VA & $\mathbf{R}$ & $\begin{array}{ll}\text { VR } & \text { V } \\
\end{array}$ & $R$ & & & \\
\hline & $22, \mathrm{CC}$ & $F$ & VA & & & VA & & & & & & & & $R$ & VA & $R$ & R & \begin{tabular}{|l|} 
VA \\
\end{tabular} & & \begin{tabular}{l|l} 
\\
\end{tabular} & & & & \\
\hline & 23-1, 93-94 & $F$ & VA & & & $\mathrm{VA}$ & & & & & & & & $\mathbf{R}$ & VA & & R & VA & VR & & & $R$ & & \\
\hline & $23-2,93-94$ & $F$ & VA & & & VA & & & & & & & & $\mathbf{R}$ & VA & $R$ & F & VA & VR & v & R & & & \\
\hline & $23-3,23-24$ & $F$ & VA & & & IA & & & & & & & & $\mathbf{R}$ & VA & $\mathbf{R}$ & $\mathrm{F}$ & VA & $\mathrm{F}$ & v & 8 & & & \\
\hline & $23, \mathrm{cC}$ & $F$ & $\mathrm{VA}$ & & & IA & & & & & & & & $\mathbf{R}$ & VA & VR & $\mathrm{A}$ & VA & $A$ & 1 & $R$ & & $V_{A}$ & VA \\
\hline & 24-1, 94-95 & $F$ & VA & & $\mathrm{v}$ & IA & & & & & & & & $\mathbf{R}$ & VA & $\mathbf{R}$ & & VA & $R$ & $\mathrm{v}$ & $\mathbf{R}$ & \begin{tabular}{l|l}
$R$ \\
\end{tabular} & & \\
\hline
\end{tabular}


Table 9C. Distribution of calcareous nannofossils in Hole 523, Cores 24 to 41 .

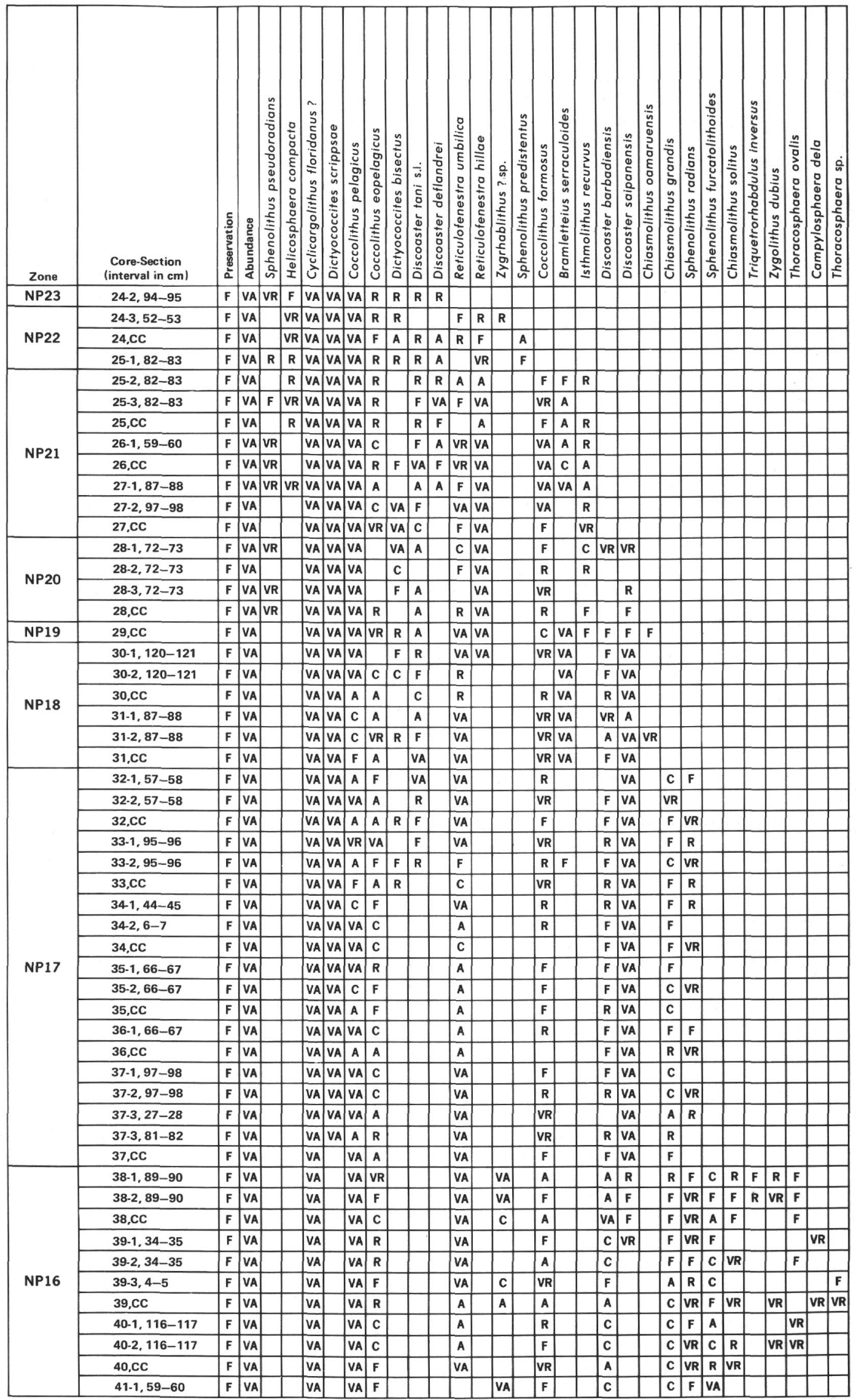


Table 9D. Distribution of calcareous nannofossils in Hole 523, Cores 41 to 50.

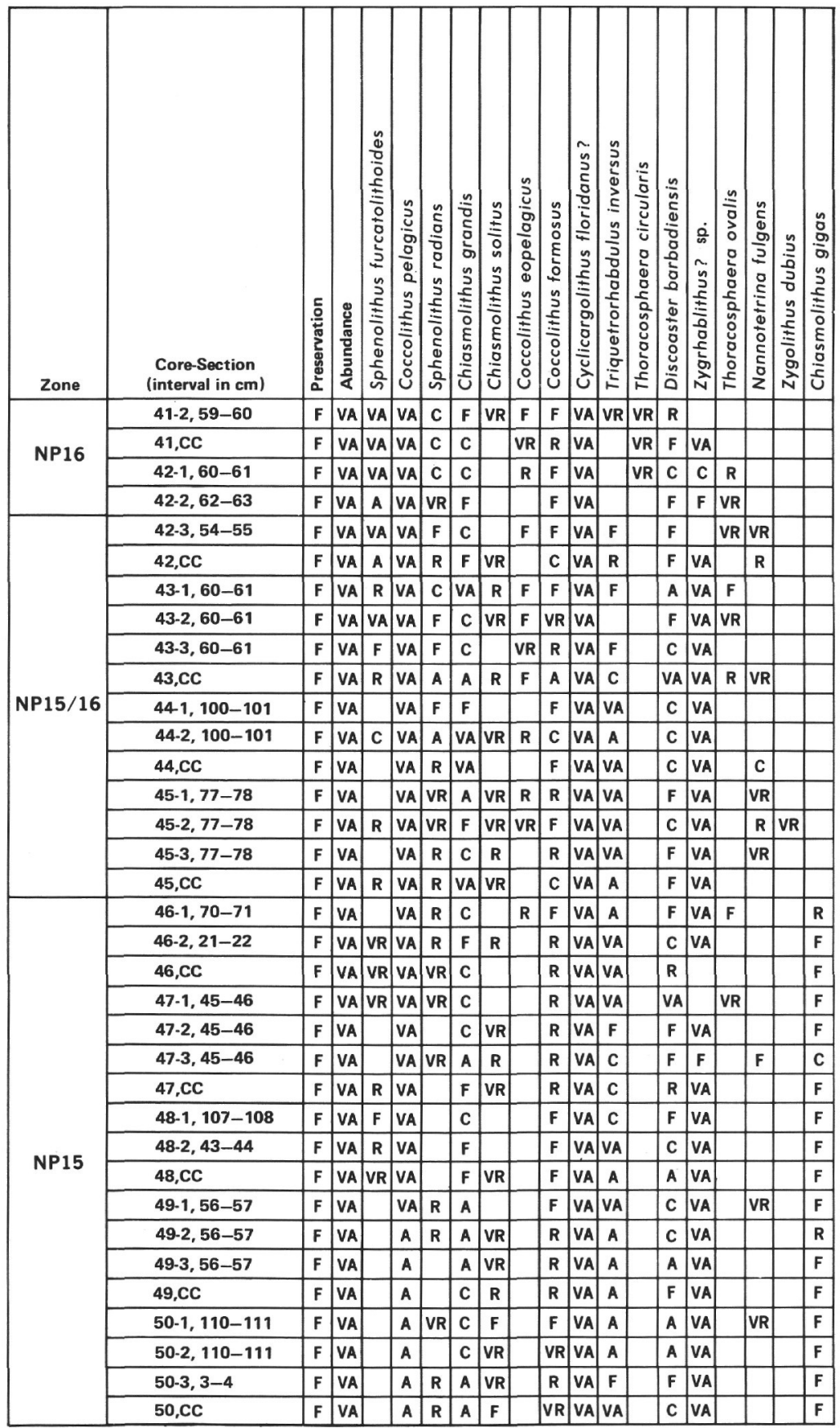


Table 10A. Distribution of calcareous nannofossils in Hole 524, Cores 1 to 11 .

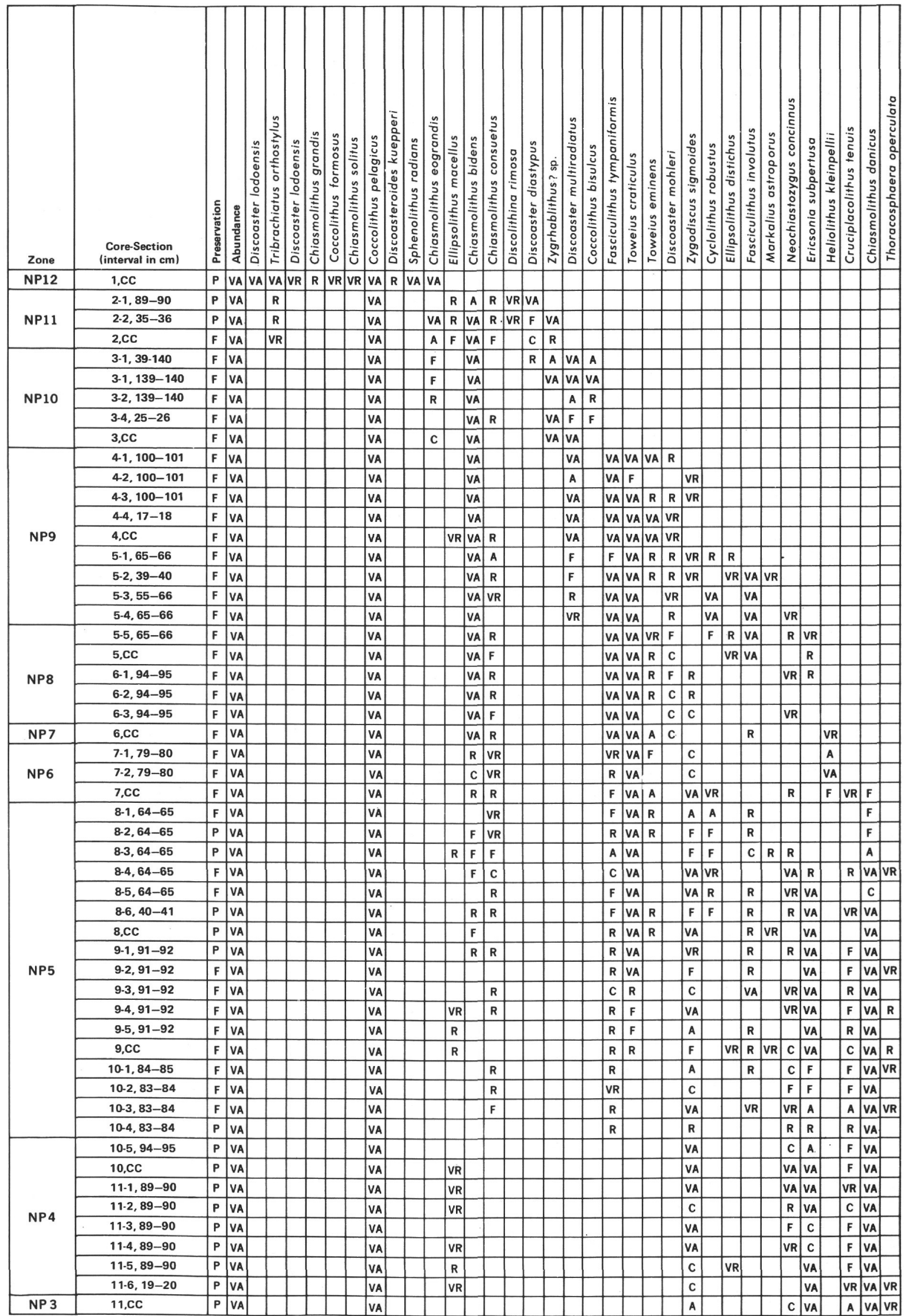


Table 10B. Distribution of calcareous nannofossils in Hole 524, Cores 12 to 20.

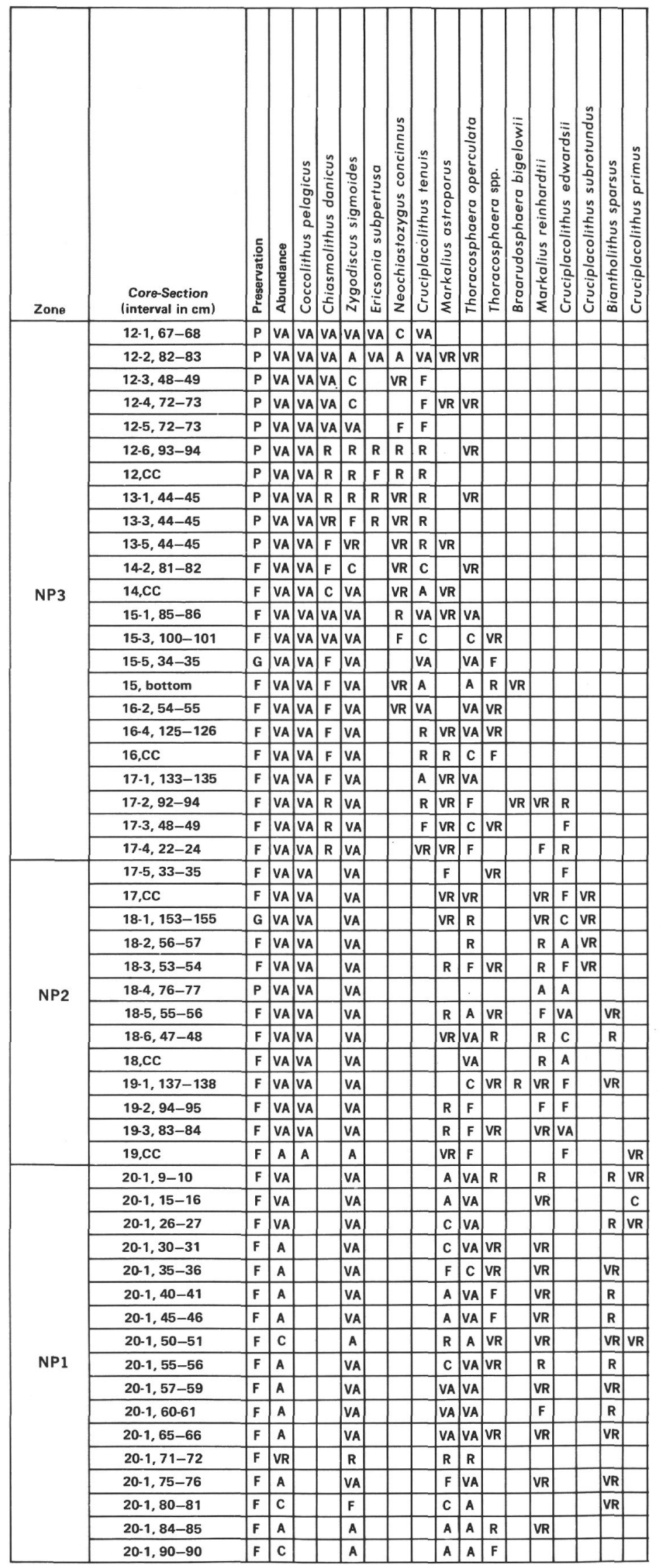


Table 10C. Distribution of calcareous nannofossils in Hole 524, Core 20.

\begin{tabular}{|c|c|c|c|c|c|c|c|c|c|c|c|c|c|c|c|c|c|c|c|c|c|c|c|c|c|c|c|c|c|}
\hline \\
\hline Zone & $\begin{array}{c}\text { Core-Section } \\
\text { (interval in cm) }\end{array}$ & 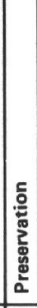 & 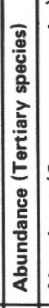 & 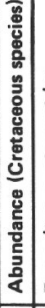 & 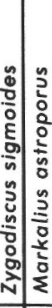 & 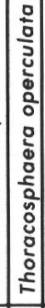 & 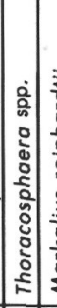 & 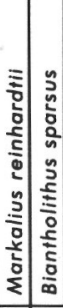 & 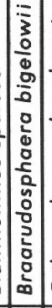 & 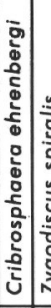 & 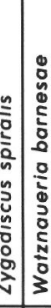 & 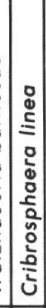 & 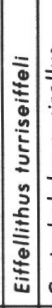 & 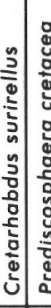 & 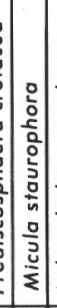 & 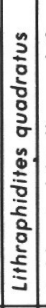 & 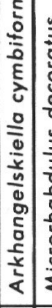 & 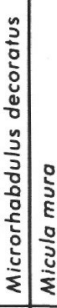 & 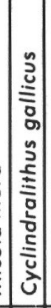 & 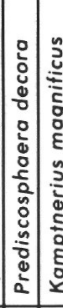 & 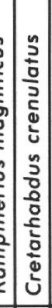 & 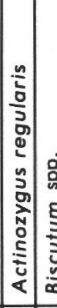 & 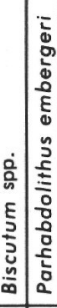 & 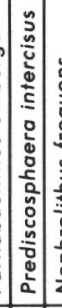 & 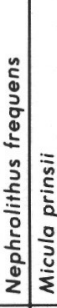 & 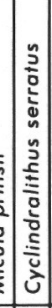 & 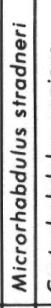 & 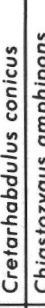 & 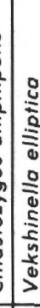 \\
\hline \multirow{49}{*}{ NP1 } & $20-1,95-96$ & $\mathbf{P}$ & VR & VR & \begin{tabular}{l|l}
$\mathbf{R}$ & $\mathbf{R}$ \\
\end{tabular} & $R$ & & & & & & & & & & & & & & & & & & & & & & & \\
\hline & 20-1, 99-101 & $\mathbf{P}$ & \begin{tabular}{|l|l}
$\mathbf{R}$ & \\
\end{tabular} & \begin{tabular}{|l|l|} 
VR \\
\end{tabular} & $\mathbf{F}$ & $\mathbf{F}$ & & $\mathbf{F}$ & & & & & & & & & & & & & & & & & & & & & \\
\hline & $20-1,100-101$ & $\mathbf{P}$ & VR & VR & \begin{tabular}{l|l}
$R$ & VR \\
\end{tabular} & $F$ & $\mathbf{R}$ & & & & & & & & & & & & & & & & & & & & & & \\
\hline & $20-1,105-106$ & $\mathbf{P}$ & VR & VR & \begin{tabular}{l|l}
$R$ & $R$ \\
\end{tabular} & c & & VR & & & & & & & & & & & & & & & & & & & & & \\
\hline & 20-1, 110-111 & & \begin{tabular}{|l|} 
\\
\end{tabular} & & & & & & & & & & & & & & & & & & & & & & & & & & \\
\hline & $20-1,119-120$ & & B & & & & & & & & & & & & & & & & & & & & & & & & & & \\
\hline & $20-1,124-125$ & $\mathbf{P}$ & VR & VR & $\mathbf{R}$ & VR & & & & & & & & & & & & & & & & & & & & & & & \\
\hline & $20-1,129-130$ & $\mathbf{P}$ & VR & VR & $\begin{array}{ll}\text { VR } \\
\text { VR }\end{array}$ & VR & & \begin{tabular}{l|l}
$R$ & $V R$ \\
\end{tabular} & & & & & & & & & & & & & & & & & & & & & \\
\hline & $20-1,135-136$ & $\mathbf{P}$ & VR & VR & \begin{tabular}{l|l}
$R$ & VR \\
\end{tabular} & $R$ & & & & & & & & & & & & & & & & & & & & & & & \\
\hline & $20-1.140-141$ & $\mathbf{P}$ & UR & VR & \begin{tabular}{l|l}
$F$ & $F$ \\
\end{tabular} & $\mathbf{F}$ & & & & & & & & & & & & & & & & & & & & & & & \\
\hline & $20-1,145-146$ & & B & B & & & & & & & & & & & & & & & & & & & & & & & & & \\
\hline & $20-2,14-15$ & $\mathbf{F}$ & A & VR & \begin{tabular}{l|l} 
VA & A \\
\end{tabular} & va & VR & VR & VR & & & & & & & & & & & & & & & & & & & & \\
\hline & $20-2,23-24$ & $F$ & A & VR & \begin{tabular}{l|l} 
c & A \\
\end{tabular} & va & & & & & & & & & & & & & & & & & & & & & & & \\
\hline & $20-2,42-43$ & $\mathbf{F}$ & A & VR & $\begin{array}{l}A \\
V A A\end{array}$ & VA & & \begin{tabular}{l|l} 
VR & $R$ \\
\end{tabular} & & & & & & & & & & & & & & & & & & & & & \\
\hline & $20-2,52-53$ & $\mathbf{F}$ & va & VR & \begin{tabular}{l|l|l} 
VA & VA \\
\end{tabular} & VA & & VR & & & & & & & & & & & & & & & & & & & & & \\
\hline & $20-2,53-54$ & $\mathbf{F}$ & A & VR & \begin{tabular}{l|l} 
VA & A \\
\end{tabular} & VA & & $\mathbf{R}$ & & & & & & & & & & & & & & & & & & & & & \\
\hline & $20-2,60-61$ & $\mathbf{F}$ & A & VR & \begin{tabular}{l|l} 
A & $V A$ \\
\end{tabular} & $A$ & & VR & & & & & & & & & & & & & & & & & & & & & \\
\hline & $20-2,67-69$ & $\mathbf{F}$ & c & \begin{tabular}{|l|} 
VR \\
\end{tabular} & \begin{tabular}{l|l} 
VA & $A$ \\
\end{tabular} & $A$ & & \begin{tabular}{l|l} 
VR & \\
\end{tabular} & & \begin{tabular}{l|l}
$R$ & $V$ \\
\end{tabular} & $\begin{array}{l}\text { VR } \\
R\end{array}$ & $R$ & $\begin{array}{ll}R & V \\
\end{array}$ & $\begin{array}{ll}\text { VR } & R \\
\end{array}$ & $\mathbf{R}$ & VR & & & & & & & & & & & & & \\
\hline & $20-2,74-75$ & $F$ & va & \begin{tabular}{l|l}
$c$ & 1 \\
\end{tabular} & \begin{tabular}{l|l} 
VA & VA \\
\end{tabular} & va & VR V & \begin{tabular}{l|l|} 
VR & $R$ \\
\end{tabular} & VR & \begin{tabular}{l|l}
$R$ \\
\end{tabular} & c & VR & c $\mathrm{V}$ & \begin{tabular}{l|l} 
VR & $\mathrm{C}$ \\
\end{tabular} & $F$ & & \begin{tabular}{|l|l}
$F$ & $F$ \\
\end{tabular} & \begin{tabular}{l|l}
$\mathbf{R}$ & \\
\end{tabular} & & & & & & & & & & & \\
\hline & $20-2,91-92$ & $\mathbf{F}$ & va & c| & \begin{tabular}{l|l}
$\mathrm{VA}$ & $\mathrm{A}$ \\
\end{tabular} & VA & & \begin{tabular}{l|l|} 
VR & $F$ \\
\end{tabular} & & \begin{tabular}{|l|l|} 
VR & V \\
\end{tabular} & \begin{tabular}{l|l|}
$\mathrm{VR}$ & $F$ \\
\end{tabular} & & \begin{tabular}{|l|l}
$F$ \\
\end{tabular} & \begin{tabular}{l|l|} 
VR & $F$ \\
\end{tabular} & $F$ & & \begin{tabular}{|l|l|}
$\mathbf{F}$ & \\
\end{tabular} & \begin{tabular}{l|l} 
VR \\
\end{tabular} & VR & & & & & & & & & & \\
\hline & $20-2,98-99$ & $\mathbf{P}$ & vR & \begin{tabular}{|l|l|} 
\\
\end{tabular} & $\begin{array}{l}\mathbf{F} \\
\end{array}$ & $R$ & & \begin{tabular}{l|l} 
& $F$ \\
\end{tabular} & & & $\begin{array}{l}\mathrm{R} \\
\end{array}$ & VR & & $\begin{array}{ll}\text { VR } \\
\end{array}$ & VR & & \begin{tabular}{l|l|l} 
VR & V \\
\end{tabular} & \begin{tabular}{l|l} 
VR & \\
\end{tabular} & & & & & & & & & & & \\
\hline & $202,104-105$ & $\mathbf{F}$ & va & VR & \begin{tabular}{l|l} 
VA & A \\
\end{tabular} & VA & & \begin{tabular}{l|l} 
VR & $F$ \\
\end{tabular} & & & $\begin{array}{lll}R & F \\
\end{array}$ & & $F$ & $F$ & $\mathbf{F}$ & & \begin{tabular}{|l|l|}
$F$ & $V$ \\
\end{tabular} & VR & & \begin{tabular}{|l|l|l} 
VR & VF \\
\end{tabular} & & & & & & & & & \\
\hline & $20-2,110-111$ & $\mathbf{F}$ & VA & \begin{tabular}{l|l}
$F$ & \\
\end{tabular} & \begin{tabular}{l|l} 
VA & $F$ \\
\end{tabular} & VA & & \begin{tabular}{l|l|} 
VR & $F$ \\
\end{tabular} & & & \begin{tabular}{l|l} 
VR & $F$ \\
\end{tabular} & & $F$ & $\mathbf{F}$ & $F$ & & \begin{tabular}{|l|l|l}
$F$ & $V$ \\
\end{tabular} & VR & & & VR & VR & & & & & & & \\
\hline & $20-2,116-117$ & $\mathbf{F}$ & va & VR & $\begin{array}{ll} & V A \\
\end{array}$ & va & $F$ & \begin{tabular}{l|l|}
$R$ & $V R$ \\
\end{tabular} & & & \begin{tabular}{l|l|l|} 
VR & $F$ \\
\end{tabular} & & VR & & & & \begin{tabular}{l|l} 
VR & V \\
\end{tabular} & VR & & & & & $\mathbf{R}$ & & & & & & \\
\hline & $20-2,123-124$ & $\mathbf{F}$ & A & \begin{tabular}{|l|l|}
$F$ \\
\end{tabular} & \begin{tabular}{l|l}
$A$ & $F$ \\
\end{tabular} & $A$ & & VR & & VR & $F$ & & $\mathbf{F}$ & $F$ & $F$ & & \begin{tabular}{|l|l}
$\mathbf{F}$ & $\mathbf{F}$ \\
\end{tabular} & $\mathbf{R}$ & VR & & VR & & \begin{tabular}{l|l} 
VR & VR \\
\end{tabular} & & & & & & \\
\hline & $20-2,131-132$ & $\mathbf{F}$ & $\mathbf{F}$ & \begin{tabular}{|l|}
$F$ \\
\end{tabular} & \begin{tabular}{l|l}
$A$ & $F$ \\
\end{tabular} & $F$ & & $\mathbf{F}$ & & & \begin{tabular}{l|l} 
VR & $F$ \\
\end{tabular} & & $F$ & vF & $\begin{array}{ll}\mathrm{R} & \mathrm{F} \\
\end{array}$ & & \begin{tabular}{|l|l|}
$R$ & $F$ \\
\end{tabular} & $\mathbf{R}$ & & & VR & & & & & & & & \\
\hline & $20-2,137-138$ & $\mathbf{F}$ & \begin{tabular}{|l|l|}
$c$ \\
\end{tabular} & $\mathbf{F}$ & \begin{tabular}{l|l}
$c$ & $R$ \\
\end{tabular} & va & & \begin{tabular}{l|l|} 
VR & $R$ \\
\end{tabular} & & VR & $\mathrm{F}$ & & $F$ & VR Vr & \begin{tabular}{|l|l|}
$R$ & $F$ \\
\end{tabular} & & \begin{tabular}{|l|l|}
$\mathbf{R}$ & \\
\end{tabular} & & & VR & & & & $R$ & & & & & \\
\hline & $20-2,143-144$ & $\mathbf{F}$ & A & \begin{tabular}{|l|l|} 
A \\
\end{tabular} & \begin{tabular}{l|l}
$A$ & $R$ \\
\end{tabular} & va & & \begin{tabular}{l|l|}
$R$ & $C$ \\
\end{tabular} & & \begin{tabular}{|l|l|}
$R$ & $V$ \\
\end{tabular} & \begin{tabular}{l|l} 
VR & $F$ \\
\end{tabular} & & c & \begin{tabular}{l|l} 
VR & $F$ \\
\end{tabular} & $\mathrm{VA}$ & $F$ & \begin{tabular}{l|l|l}
$c$ & $v$ \\
\end{tabular} & VR & & & & & & & \begin{tabular}{l|l} 
VR & $R$ \\
\end{tabular} & & & & \\
\hline & 20-2, 148-149 & $\mathbf{F}$ & va & \begin{tabular}{l|l} 
c & 1 \\
\end{tabular} & \begin{tabular}{l|l|}
$V A$ & $F$ \\
\end{tabular} & va & \begin{tabular}{|l|l}
$R$ & $F$ \\
\end{tabular} & \begin{tabular}{l|l|}
$R$ & $C$ \\
\end{tabular} & & VR & $c$ & & VR & c & A & & \begin{tabular}{l|l} 
VR & V \\
\end{tabular} & VR & & & & & & & \begin{tabular}{l|l|} 
VR & VF \\
\end{tabular} & & & & \\
\hline & $20-3,5-6$ & $\mathbf{F}$ & va & $\begin{array}{ll} & \\
\end{array}$ & \begin{tabular}{l|l} 
VA & A \\
\end{tabular} & $A$ & \begin{tabular}{|l|}
$\mathbf{F}$ \\
\end{tabular} & \begin{tabular}{l|l} 
& $A$
\end{tabular} & & & \begin{tabular}{l|l} 
VR & A \\
\end{tabular} & VR & $c$ & $\mathrm{c}$ & VA & $F$ & \begin{tabular}{l|l|l}
$c$ & $v$ \\
\end{tabular} & VR & VR & VR & & & \begin{tabular}{l|l|} 
VR & VR \\
\end{tabular} & & \begin{tabular}{l|l} 
VR & VF \\
\end{tabular} & & & & \\
\hline & $20-3,10-11$ & $\mathbf{F}$ & VA & VA & \begin{tabular}{l|l} 
VA & A \\
\end{tabular} & VA & & c & & & $F$ & VR & $F$ & C & VA & VR & \begin{tabular}{|l|l} 
c & \\
\end{tabular} & & VR & VR & & & VR & VR & $\mathbf{F}$ & VR & VR & & \\
\hline & $20-3,15-16$ & $\mathbf{F}$ & VA & $A \mid$ & $\begin{array}{l}\text { VA } \\
\text { VA }\end{array}$ & VA & & $\mathbf{F}$ & & \begin{tabular}{|l|l|l|} 
VR \\
\end{tabular} & \begin{tabular}{l|l} 
VR & $F$ \\
\end{tabular} & VR & $\mathbf{F}$ & \begin{tabular}{l|l}
$R$ & $A$ \\
\end{tabular} & VA & $\mathbf{F}$ & \begin{tabular}{|l|l|l}
$A$ & $V$ \\
\end{tabular} & VR & & VR & & & \begin{tabular}{l|l} 
VR & \\
\end{tabular} & & $\mathbf{R}$ & & 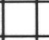 & & \\
\hline & $20-3,20-21$ & $\mathbf{F}$ & VA & VA & \begin{tabular}{l|l} 
VA & C \\
\end{tabular} & VA & & c & & \begin{tabular}{|l|l|l|} 
VR \\
\end{tabular} & \begin{tabular}{l|l} 
VR & $F$ \\
\end{tabular} & & va & $\begin{array}{ll}\text { VR } & \mathrm{C} \\
\end{array}$ & VA & $\mathbf{F}$ & \begin{tabular}{|l|l|l}
$R$ & $V$ \\
\end{tabular} & VR & VR & & VR & & & & \begin{tabular}{l|l}
$V R$ & $R$ \\
\end{tabular} & & VR V & IR & \\
\hline & $20-3,25-26$ & $\mathbf{F}$ & VA & $\begin{array}{ll} \\
\end{array}$ & $\begin{array}{ll}\text { VA } \\
\end{array}$ & $v a$ & & \begin{tabular}{l|l}
$A$ & C \\
\end{tabular} & & \begin{tabular}{|l|l|} 
VR \\
\end{tabular} & \begin{tabular}{l|l} 
VR & $F$ \\
\end{tabular} & & c & \begin{tabular}{l|l} 
VR & C \\
\end{tabular} & VA & $\mathbf{F}$ & \begin{tabular}{|l|l|}
$\mathbf{F}$ & \\
\end{tabular} & & & \begin{tabular}{|l|l|} 
VR \\
\end{tabular} & VR & & & & \begin{tabular}{l|l} 
VR & \\
\end{tabular} & & \begin{tabular}{|l|l|} 
VR \\
\end{tabular} & vr & \\
\hline & $20-3,30-31$ & $\mathbf{F}$ & va & \begin{tabular}{|l|l}
$A$ & 1 \\
\end{tabular} & \begin{tabular}{l|l} 
VA & $F$ \\
\end{tabular} & va & & \begin{tabular}{l|l|}
$V A$ & $C$ \\
\end{tabular} & & \begin{tabular}{|l|l|} 
VR & V \\
\end{tabular} & $\begin{array}{ll}\mathrm{VR} & \mathrm{R} \\
\end{array}$ & & VR & $\begin{array}{l}F \\
\end{array}$ & VA & & \begin{tabular}{|l|l|}
$A$ & \\
\end{tabular} & \begin{tabular}{l|l} 
& $R$ \\
\end{tabular} & & \begin{tabular}{l|l} 
& vr \\
\end{tabular} & & & VR & \begin{tabular}{|l|} 
VR \\
\end{tabular} & \begin{tabular}{l|l} 
& $R$ \\
\end{tabular} & & VR & & \\
\hline & $20-3,36-37$ & $\mathbf{F}$ & VA & VA & $\begin{array}{ll}\text { VA } & \text { VA } \\
\end{array}$ & VA & & \begin{tabular}{l|l}
$V A$ & $F$ \\
\end{tabular} & & \begin{tabular}{l|l} 
VR & $F$ \\
\end{tabular} & \begin{tabular}{l|l}
$R$ & $F$ \\
\end{tabular} & & VR & \begin{tabular}{l|l} 
VR & $A$ \\
\end{tabular} & VA & $F$ & \begin{tabular}{|l|l|}
$A$ & $V$ \\
\end{tabular} & \begin{tabular}{l|l} 
VR \\
\end{tabular} & & & & & $\mathbf{R}$ & VR V & \begin{tabular}{l|l} 
VR & $R$ \\
\end{tabular} & & VR & VF & \begin{tabular}{l|l}
$R$ & VR \\
\end{tabular} \\
\hline & $20-3,42-43$ & $\mathbf{F}$ & A & A & \begin{tabular}{l|l}
$A$ & $F$ \\
\end{tabular} & $A$ & & \begin{tabular}{l|l}
$F$ & $C$ \\
\end{tabular} & & \begin{tabular}{|l|l}
$F$ & $V$ \\
\end{tabular} & \begin{tabular}{l|l} 
VR & $F$ \\
\end{tabular} & & $\mathbf{F}$ & \begin{tabular}{l|l} 
VR & $A$ \\
\end{tabular} & VA & & \begin{tabular}{|l|l}
$\mathbf{F}$ & $\mathrm{F}$ \\
\end{tabular} & $\mathbf{F}$ & & \begin{tabular}{|l|l|}
$R$ & $V F$ \\
\end{tabular} & & & VR & & \begin{tabular}{l|l}
$R$ & $R$ \\
\end{tabular} & & VR & & \\
\hline & $20-3,47-48$ & $\mathbf{F}$ & $v_{A}$ & \begin{tabular}{|l|l}
$A$ & 1 \\
\end{tabular} & \begin{tabular}{l|l} 
VA & A \\
\end{tabular} & va & & \begin{tabular}{l|l|}
$c$ & $c$ \\
\end{tabular} & & \begin{tabular}{|l|l|}
$R$ & $V$ \\
\end{tabular} & \begin{tabular}{l|l} 
VR & $F$ \\
\end{tabular} & $R$ & \begin{tabular}{l|l} 
\\
\end{tabular} & \begin{tabular}{l|l|}
$\mathrm{VR}$ & $\mathrm{C}$ \\
\end{tabular} & VA & $\mathbf{F}$ & \begin{tabular}{l|l|l}
$c$ & $v$ \\
\end{tabular} & VR & & \begin{tabular}{|l|l|}
$V R$ & VF \\
\end{tabular} & & & $\mathbf{F}$ & & \begin{tabular}{l|l|}
$R$ & VR \\
\end{tabular} & & & & VR \\
\hline & $20-3,52-53$ & $\mathbf{F}$ & va & VA & \begin{tabular}{l|l}
$\mathrm{VA}$ & $F$ \\
\end{tabular} & VA & & \begin{tabular}{l|l|}
$V A$ & $C$ \\
\end{tabular} & & \begin{tabular}{|l|l|}
$R$ & $V$ \\
\end{tabular} & \begin{tabular}{l|l} 
VR & $F$ \\
\end{tabular} & & A I & \begin{tabular}{l|l} 
VR & A \\
\end{tabular} & VA & $\mathbf{F}$ & \begin{tabular}{l|l}
$V A$ & $F$ \\
\end{tabular} & $\mathbf{F}$ & & \begin{tabular}{|l|} 
VR \\
\end{tabular} & & \begin{tabular}{|l|l|l|} 
VR & \\
\end{tabular} & VR & & \begin{tabular}{l|l}
$R$ & VF \\
\end{tabular} & & VR & & \\
\hline & $20-3,61-62$ & $\mathbf{F}$ & va & VA & \begin{tabular}{l|l} 
c & c \\
\end{tabular} & va & & \begin{tabular}{l|l|}
$V A$ & $F$ \\
\end{tabular} & & \begin{tabular}{|l|l|} 
VR & $V$ \\
\end{tabular} & \begin{tabular}{l|l|} 
VR & $F$ \\
\end{tabular} & & \begin{tabular}{|l|l|} 
c \\
\end{tabular} & A & va & VR & \begin{tabular}{l|l} 
A & F \\
\end{tabular} & $\mathbf{F}$ & & VR & & & VR & & VF & & & & \\
\hline & $20-3,66-67$ & $\mathbf{F}$ & va & A & \begin{tabular}{l|l}
$F$ & $F$ \\
\end{tabular} & va & & \begin{tabular}{l|l|l}
$V A$ & $V A$ \\
\end{tabular} & & \begin{tabular}{|l|l} 
VR & F \\
\end{tabular} & \begin{tabular}{l|l}
$R$ & $F$ \\
\end{tabular} & VR & A & \begin{tabular}{l|l}
$R$ & $C$ \\
\end{tabular} & VA & $F$ & \begin{tabular}{|l|l|}
$A$ & $V$ \\
\end{tabular} & \begin{tabular}{l|l} 
VR & \\
\end{tabular} & & & & & & & \begin{tabular}{l|l|l}
$R$ & VF \\
\end{tabular} & & & & \\
\hline & $20-3,73-74$ & $F$ & va & VA & \begin{tabular}{l|l|l}
$F$ & VR \\
\end{tabular} & $V A$ & & \begin{tabular}{l|l}
$V A$ & $R$ \\
\end{tabular} & & \begin{tabular}{|l|l|} 
VR & $\mathrm{V}$ \\
\end{tabular} & \begin{tabular}{l|l|} 
VR & $F$ \\
\end{tabular} & $R$ & A & \begin{tabular}{l|l}
$\mathbf{R}$ & $\mathrm{Vr}$ \\
\end{tabular} & \begin{tabular}{|l|} 
VA \\
\end{tabular} & VR & \begin{tabular}{l|l|l}
$v a$ & $V$ \\
\end{tabular} & \begin{tabular}{l|l} 
VR & VR \\
\end{tabular} & VR & & & & VR & \begin{tabular}{|l|l} 
VR & \\
\end{tabular} & \begin{tabular}{l|l}
$R$ & VF \\
\end{tabular} & & & lv & \\
\hline & $20-3,79-80$ & $\mathbf{F}$ & VA & VA & \begin{tabular}{l|l}
$F$ & $R$ \\
\end{tabular} & VA & & \begin{tabular}{l|l|l} 
VA & VR \\
\end{tabular} & & VR & \begin{tabular}{l|l}
$R$ & $C$ \\
\end{tabular} & VR & VA & \begin{tabular}{l|l}
$\mathbf{R}$ & $\mathbf{A}$ \\
\end{tabular} & VA & $\mathbf{F}$ & \begin{tabular}{l|l} 
VA & $F$
\end{tabular} & \begin{tabular}{l|l}
$R$ & VR \\
\end{tabular} & $R$ & \begin{tabular}{|l|l|} 
VR & $R$ \\
\end{tabular} & & & & VR V & \begin{tabular}{l|l|} 
VR & VF \\
\end{tabular} & & & IR $\mid V F$ & \\
\hline & $20-3,85-86$ & $\mathbf{F}$ & VA & VA & \begin{tabular}{l|l} 
& VF \\
\end{tabular} & $A$ & & \begin{tabular}{l|l} 
VA & VR \\
\end{tabular} & & \begin{tabular}{|l|l|}
$R$ & $V$ \\
\end{tabular} & \begin{tabular}{l|l} 
VR & $F$ \\
\end{tabular} & VR & A & VR VF & VA & VR & VA & \begin{tabular}{l|l} 
VR \\
\end{tabular} & & \begin{tabular}{|l|l|}
$R$ & $V r$ \\
\end{tabular} & & VR V V & VR & VR $\mathrm{V}$ & \begin{tabular}{l|l}
$V R$ & $R$ \\
\end{tabular} & & & & \\
\hline & $20-3,91-92$ & $\mathbf{F}$ & A & ViA & \begin{tabular}{l|l} 
VF \\
\end{tabular} & $F$ & & \begin{tabular}{l|l} 
VA & \\
\end{tabular} & & \begin{tabular}{|l|l}
$R$ & \\
\end{tabular} & \begin{tabular}{l|l}
$R$ & $C$ \\
\end{tabular} & VR & \begin{tabular}{|l|} 
A \\
\end{tabular} & \begin{tabular}{l|l}
$R$ & $V$ \\
$V$
\end{tabular} & \begin{tabular}{|l|l|} 
& \\
\end{tabular} & $\mathbf{F}$ & VAT & VR & $R$ & \begin{tabular}{|l|l|}
$R$ & VF \\
\end{tabular} & $\begin{array}{ll}\mathrm{VR} \\
\end{array}$ & & VR & VR & \begin{tabular}{l|l}
$R$ & $R$ \\
\end{tabular} & & & & \\
\hline & $20-3,96-97$ & $\mathbf{F}$ & \begin{tabular}{|l|l} 
c \\
\end{tabular} & \begin{tabular}{|l|l}
$c$ \\
\end{tabular} & $\mathbf{F}$ & $\mathbf{R}$ & & A & & VR & c & & A & VR VF & VA & & \begin{tabular}{l|l} 
VA & F \\
\end{tabular} & $\mathbf{R}$ & VR & & VR & & & VR V V & \begin{tabular}{l|l} 
VR \\
\end{tabular} & & & v & \\
\hline & 20-3, 98-99 & $\mathbf{F}$ & $\mathbf{R}$ & VA & \begin{tabular}{l|l|}
$R$ & VR \\
\end{tabular} & $R$ & & $\mathbf{F}$ & & VR V V & \begin{tabular}{l|l}
$R$ & $F$ \\
\end{tabular} & $\mathbf{R}$ & VA & vi & \begin{tabular}{|l|l|} 
A & \\
\end{tabular} & VR & \begin{tabular}{l|l}
$V A$ & $V$ \\
\end{tabular} & VR & & & & VR & & VR & \begin{tabular}{l|l} 
VR & VR \\
\end{tabular} & & & vi & \\
\hline & $20-3,99-100$ & $\mathbf{F}$ & |VR & VA & \begin{tabular}{l|l}
$\mathbf{R}$ & \\
\end{tabular} & $\mathbf{R}$ & & $\mathbf{R}$ & & \begin{tabular}{|l|} 
VR \\
\end{tabular} & \begin{tabular}{l|l|}
$R$ & $V A$ \\
\end{tabular} & & VA & vo & A & $\mathbf{R}$ & \begin{tabular}{l|l}
$V A$ & $F$
\end{tabular} & $\mathbf{R}$ & & \begin{tabular}{l|l|}
$V R$ & $V F$ \\
\end{tabular} & & VR & & VR & \begin{tabular}{l|l}
$C$ & $R$ \\
\end{tabular} & & & v & \\
\hline & $20-3,102-103$ & $F$ & VR & VA & $\mathbf{R}$ & $R$ & & $\mathbf{R}$ & & \begin{tabular}{|l|l|}
$\mathbf{F}$ \\
\end{tabular} & A & $R$ & A & VR & A VA & VR & \begin{tabular}{l|l}
$V A$ & $F$
\end{tabular} & $\mathbf{R}$ & VR & \begin{tabular}{|l|l}
$R$ & $R$ \\
\end{tabular} & & & $\begin{array}{l}\text { VR } \\
\text { VR } \\
\end{array}$ & VR & \begin{tabular}{l|l}
$F$ & $R$ \\
\end{tabular} & & & v & \\
\hline \multirow{3}{*}{$\begin{array}{l}\text { Micula } \\
\text { murus }\end{array}$} & 20-3, 108-109 & $\mathbf{P}$ & & $\mathbf{F}$ & & & & $\mathbf{R}$ & & & & & & vir & \begin{tabular}{|l|l|} 
& $A$ \\
\end{tabular} & & \begin{tabular}{|l|l|}
$\mathbf{R}$ & \\
\end{tabular} & & & & VR & & \begin{tabular}{l|l} 
VR & \\
\end{tabular} & & & VR & & & \\
\hline & $20-3,112-113$ & $\mathbf{P}$ & & VA & & & & VR & & VR & $\begin{array}{ll}\mathrm{R} & \mathrm{C} \\
\end{array}$ & VR & $F$ & VR Vu & 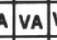 & VR & \begin{tabular}{l|l}
$V A$ & $F$ \\
\end{tabular} & $\mathbf{R}$ & & vF & & & & \begin{tabular}{|l|l}
$F$ & \\
\end{tabular} & \begin{tabular}{l|l}
$\mathbf{V R}$ & \\
\end{tabular} & & \begin{tabular}{|l|l|}
$R$ & \\
\end{tabular} & & \\
\hline & $20-3,114-116$ & $\mathbf{P}$ & & VA & & & & & & VRTV & \begin{tabular}{l|l} 
VR & C \\
\end{tabular} & & & \begin{tabular}{l|l}
$R$ & $V$ \\
\end{tabular} & \begin{tabular}{|l|l|} 
\\
\end{tabular} & & \begin{tabular}{l|l}
$V A$ & $F$
\end{tabular} & \begin{tabular}{l|l}
$F$ & $R$ \\
\end{tabular} & $R$ & \begin{tabular}{|l|l|} 
VR & VF \\
\end{tabular} & \begin{tabular}{|l|l|}
$R$ & $V R$ \\
\end{tabular} & & & \begin{tabular}{|l|}
$R$ \\
\end{tabular} & \begin{tabular}{l|l}
$\mathbf{F}$ \\
\end{tabular} & & \begin{tabular}{l|l|l}
$V R$ & $V$ \\
\end{tabular} & $\mathbf{R}$ & \\
\hline
\end{tabular}


Table 10D. Distribution of calcareous nannofossils in Hole 524, Cores 20 to 27.

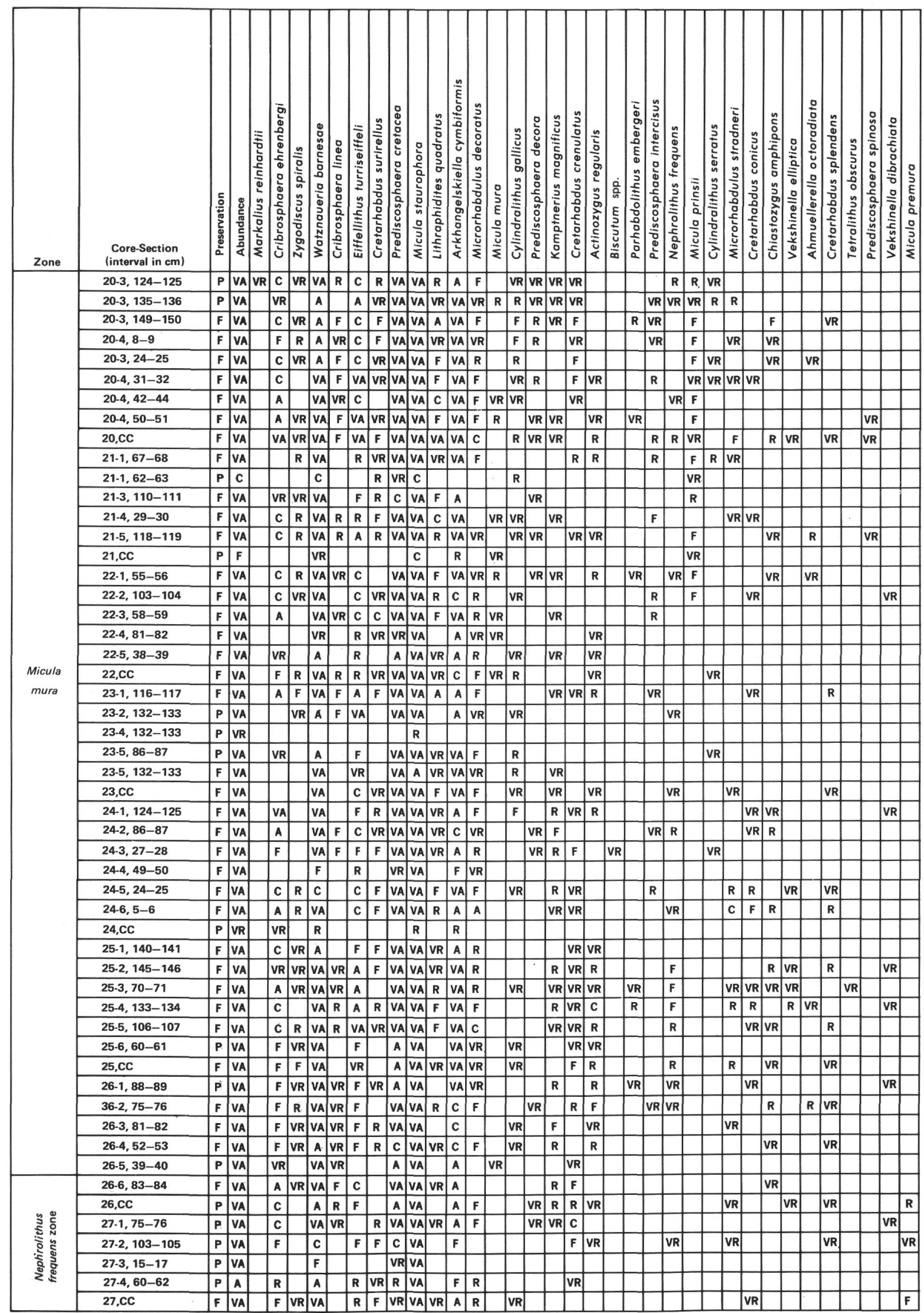


Table 10E. Distribution of calcareous nannofossils in Hole 524, Cores 28 to 35 .

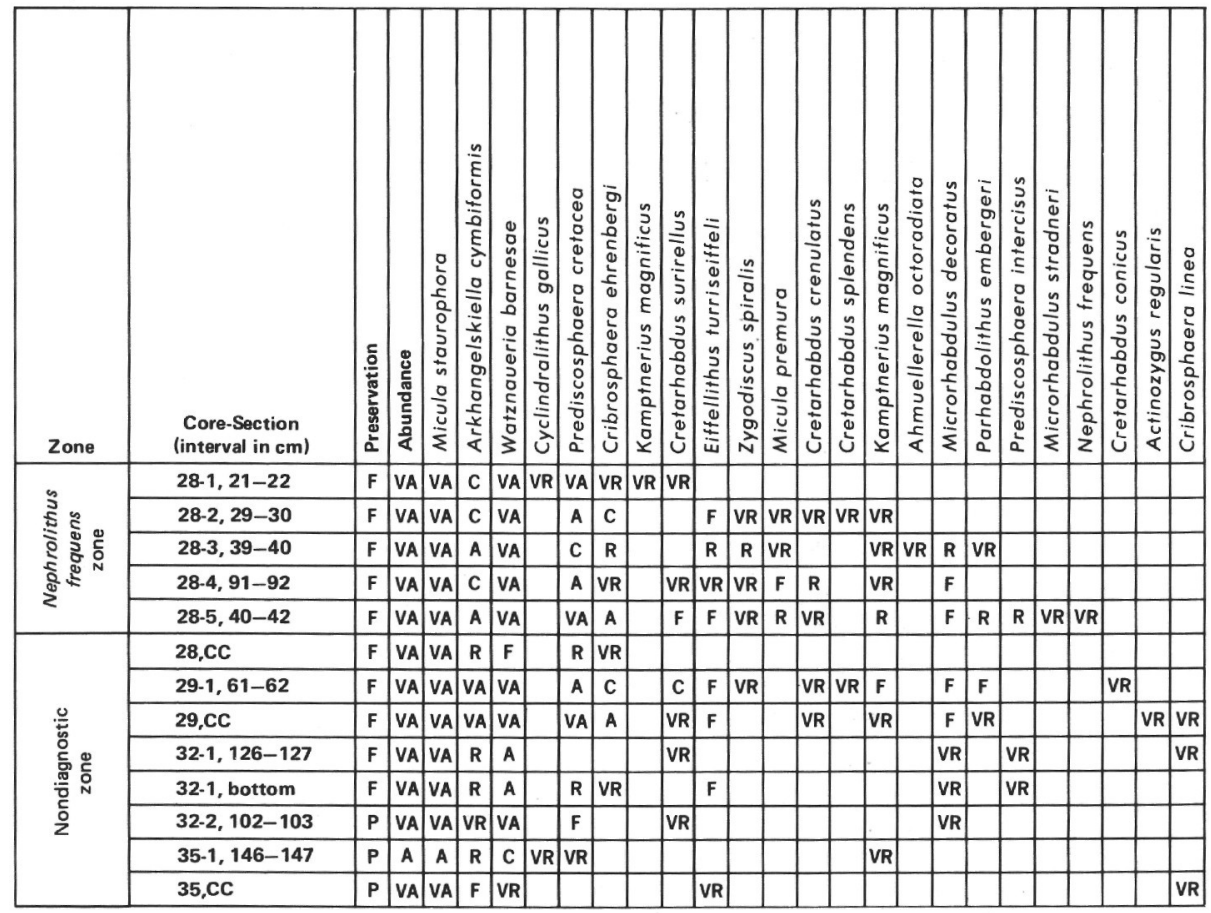

Table 11. Distribution of calcareous nannofossils in Hole 524A.

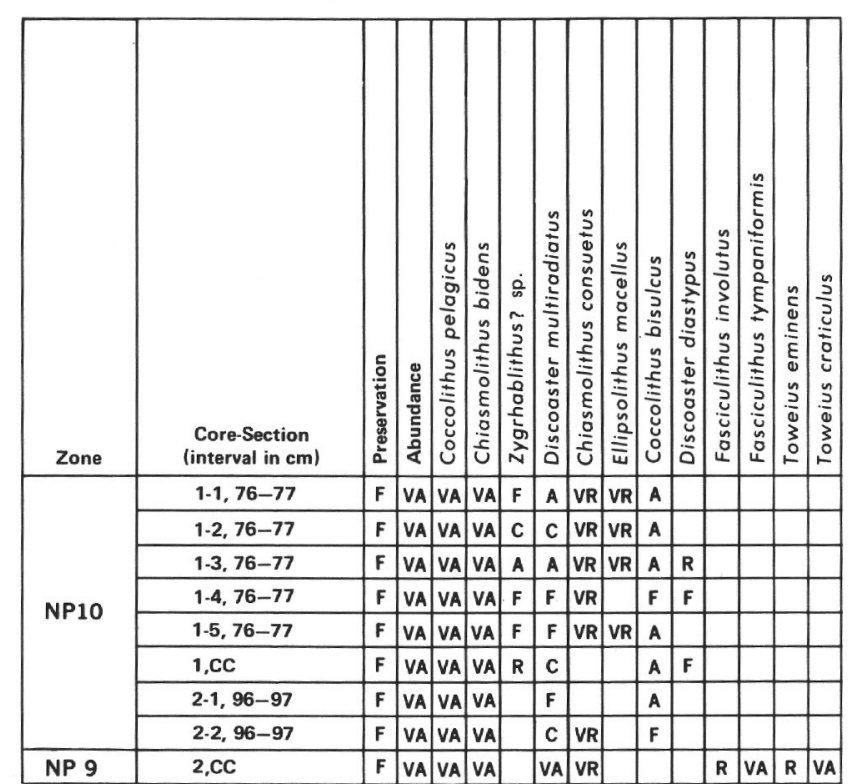


Table 12. Distribution of calcareous nannofossils in Hole 524B.

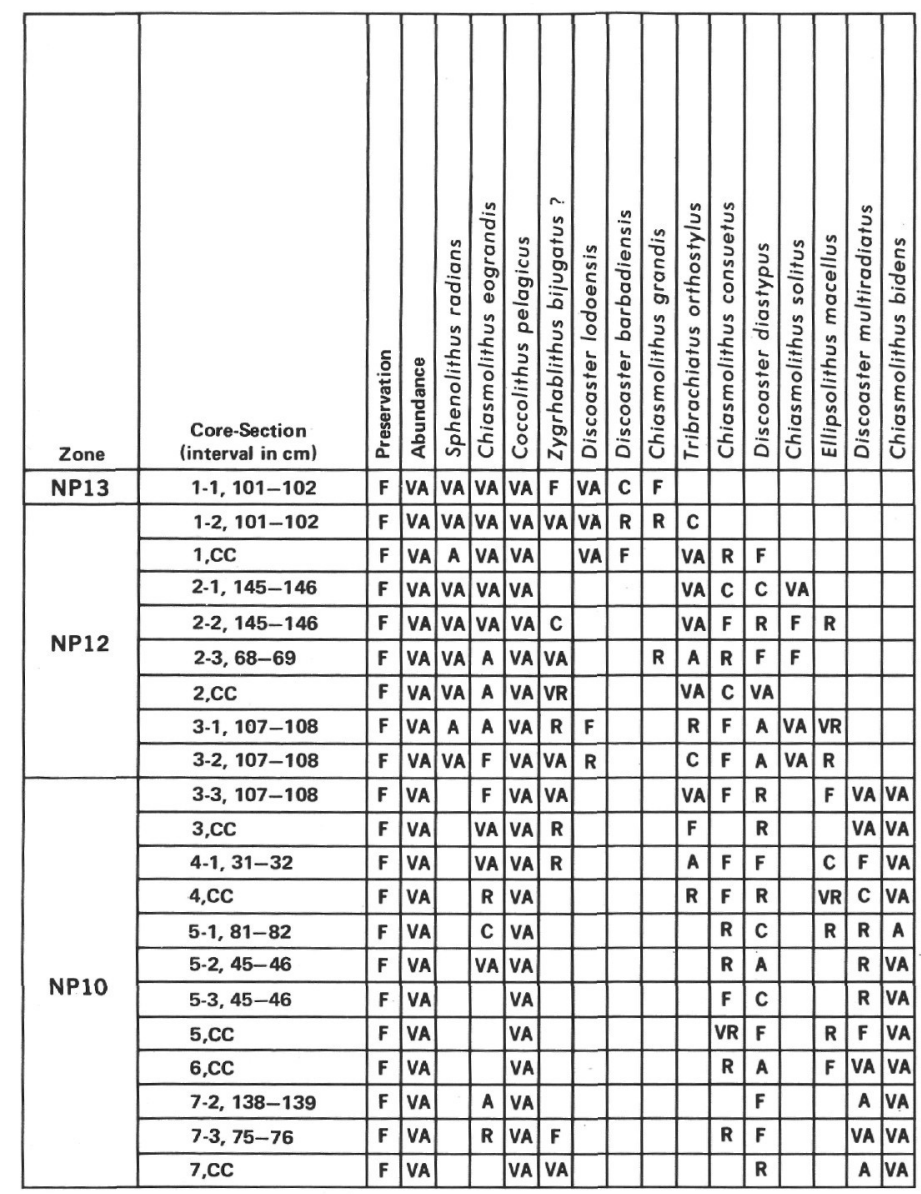

